\title{
COBERTURA DE FIBROCIMENTO E SISTEMA DE CLIMATIZAÇÃO: INFLUÊNCIA NO DESEMPENHO DE VITELOS MESTIÇOS E DA RAÇA HOLANDESA
}

\section{LUIZ CARLOS ROMA JÚNIOR}

Dissertação de Mestrado depositada na Seção de Pós-Graduação da Faculdade de Zootecnia e Engenharia de Alimentos da USP, como parte dos requisitos para a obtenção do Título de Mestre em Zootecnia, na Área de Concentração: Qualidade e Produtividade Animal

Orientador: Prof. Dr. Holmer Savastano Júnior 


\section{COBERTURA DE FIBROCIMENTO E SISTEMA DE CLIMATIZAÇÃO: INFLUÊNCIA NO DESEMPENHO DE VITELOS MESTIÇOS E DA RAÇA HOLANDESA}

\section{LUIZ CARLOS ROMA JÚNIOR}

Dissertação de Mestrado depositada na Seção de Pós-Graduação da Faculdade de Zootecnia e Engenharia de Alimentos da USP, como parte dos requisitos para a obtenção do Título de Mestre em Zootecnia, na Área de Concentração: Qualidade e Produtividade Animal

Orientador: Prof. Dr. Holmer Savastano Júnior 


\section{FICHA CATALOGRÁFICA}

preparada pela

Biblioteca da Faculdade de Zootecnia e Engenharia de Alimentos da Universidade de São Paulo

\begin{tabular}{|l|}
\hline \multirow{3}{*}{ Roma Júnior, Luiz Carlos } \\
Cobertura de fibrocimento e sistema de climatização: influência no \\
desempenho de vitelos mestiços e da raça Holandesa/ Luiz Carlos Roma \\
Júnior - Pirassununga, 2004 \\
83 p. \\
Dissertação (Mestrado) -Faculdade de Zootecnia e Engenharia de \\
Alimentos - Universidade de São Paulo. \\
Departamento de Zootecnia. \\
Área de Concentração : Qualidade e Produtividade Animal. \\
Orientador: Prof. Dr. Holmer Savastano Júnior. \\
Unitermos: 1. Construções rurais 2.Ambiência 3. Nebulização \\
4. Machos Leiteiros 5. Termorregulação. I. Título \\
\end{tabular}


"Não permaneça eternamente na via pública, indo apenas aonde os outros têm ido. Deixe o caminho batido, de vez em quando, e embrenhe-se na floresta. Certamente você encontrará algo que nunca viu antes. Naturalmente, será uma coisa pequena, mas não a ignore. Siga-a, explore-a ao seu redor; uma descoberta levará a outra e, antes que você perceba, terá algo em que vale a pena pensar." (Alexander Graham Bell) 
Aos meus pais, Luiz Carlos e Maria Ângela, pelos momentos de apoio, sacrifício e paciência, sempre ao meu lado para colaborar na superação dos obstáculos.

À minha irmã Julie, pelo incentivo e presença constante, durante toda a minha vida.

Dedico. 
"Todos nós tomamos diferentes trilhas na vida; mas não importa aonde vamos, aproveitamos um pouco de cada uma delas em toda parte. " (Tim McGrew)

À Andrezza, pelo bons momentos de companheirismo, incentivo e ajuda

Dedico. 


\section{AGRADECIMENTOS}

A Deus,

pois sem ele não teria colhido nenhum fruto na minha vida pessoal e profissional.

Ao meu orientador prof Dr. Holmer Savastano Jr, pelo direcionamento, acompanhamento e amizade.

Aos profissionais e amigos: Helena Fagundes, Luciane Silva Martello, Márcia Saladini Salles e Saulo Luz e Silva

À equipe do Laboratório de Construções Rurais e Ambiência, pela colaboração e ajuda de todos, em especial, Zaqueu Freitas

As pesquisadoras Maria da Graça Pinheiro e Cláudia Cristina Paro Paz, do Pólo Regional de Desenvolvimento do Agronegócio Centro Leste, pelo incentivo, compreensão e apoio.

Aos professores, pelo apoio e colaboração fundamental, Paulo Roberto Leme, Albino Luchiari Filho, Evaldo Antonio Lencioni Titto, João Alberto Negrão e Rubens Nunes, em especial para José Bento Sterman Ferraz (diretor FZEA) e Marcus Antonio Zanetti (prefeito do Campus USP Pirassununga)

Aos meus companheiros de moradia estudantil: Mário Adriano Ávila Queiroz, Otaviano Carneiro Neto e Weber Vilas Boas Soares.

Aos meus amigos, pelo companheirismo, Adriano R. Lucheta, Alessandra T. Fidelis, Alexandre L. Najar, Anna Cecília Uieda, Daniel C. de Oliveira, Fernando Takahashi, Glauco Figueiredo, Maurício Uieda Sobrinho, Millor F. do Rosário, Rodrigo Bergamo.

Aos funcionários da Faculdade de Zootecnia e Engenharia de Alimentos e Prefeitura do Campus Administrativo da USP de Pirassununga, pela ajuda mais que necessária.

Ao Sr. Andrew Jones, da Agropecuária CFM, pelo apoio.

A FAPESP pelo apoio financeiro para execução deste trabalho.

A CAPES pela concessão da bolsa de estudos.

Á PCAPS, pelo investimento de confiança no projeto realizado.

E a todos que tenham contribuído direta e indiretamente com este trabalho. 


\section{SUMÁRIO}

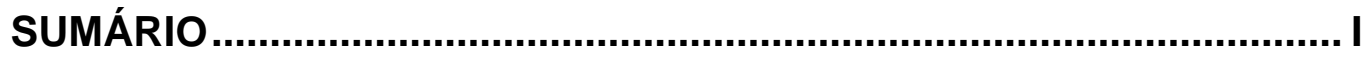

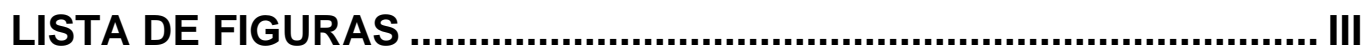

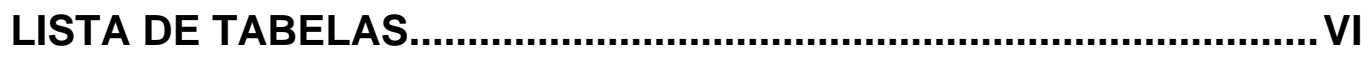

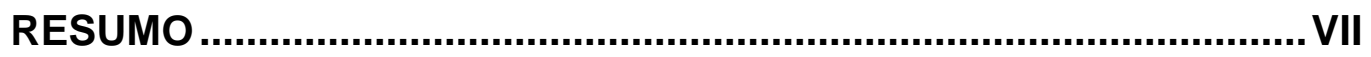

ABSTRACT

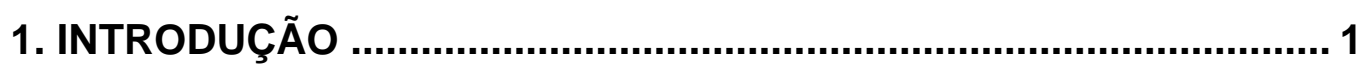

2. REVISÃO DE LITERATURA ......................................................... 4

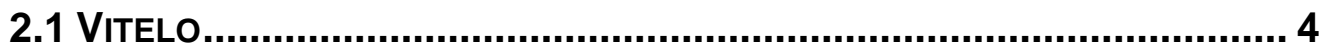

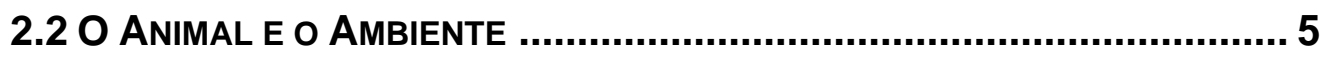

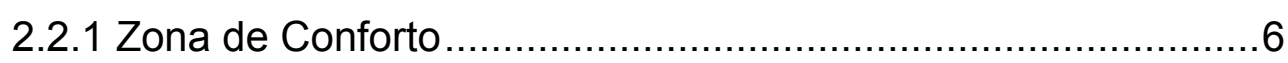

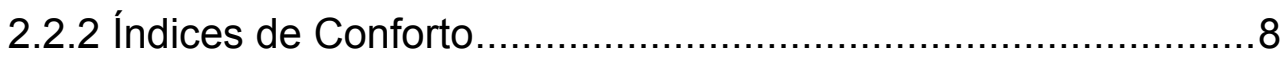

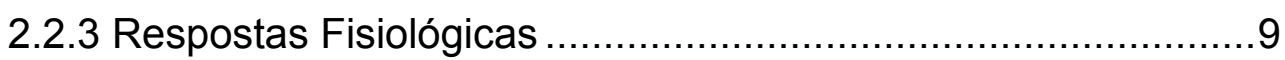

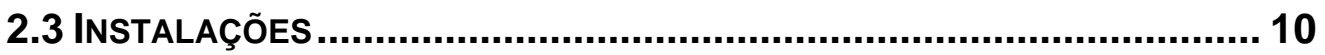

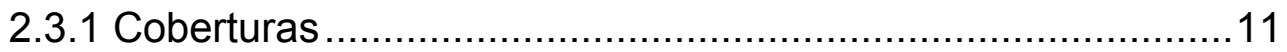

2.3.2 Modificações do Ambiente...................................................13

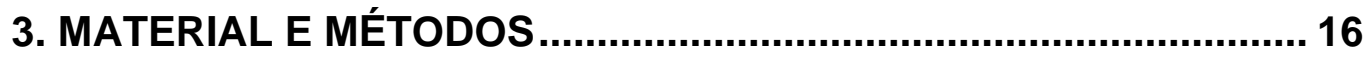

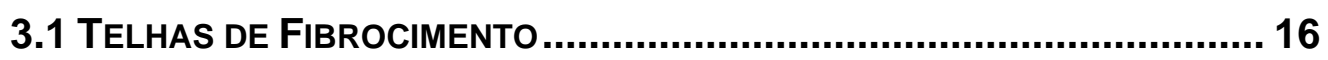

3.1.1 Produção das Telhas de Cimento Celulose ............................16

3.1.2 Caracterização das Telhas de Cimento Celulose ....................19

3.1.2.1 Propriedades Físicas ................................................ 19

3.1.2.2 Propriedades Mecânicas.............................................. 20

3.1.3 Avaliação do Desempenho Térmico das Telhas.....................21

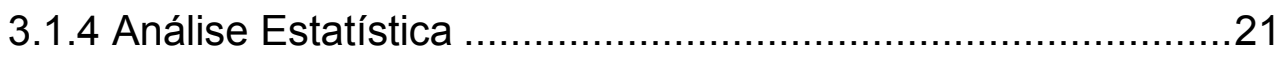

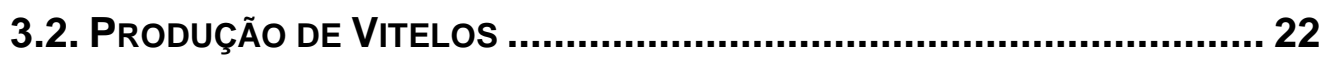

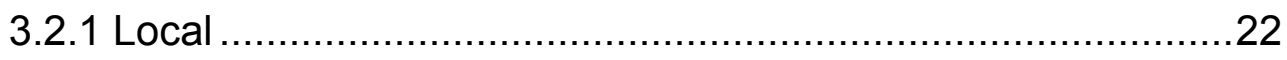




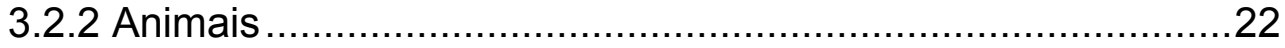

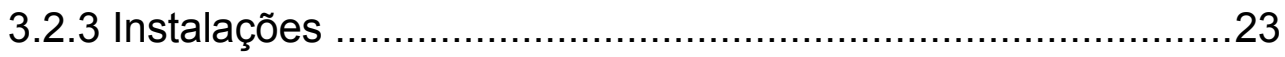

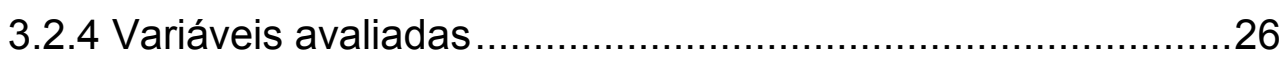

3.2.4.1 Variáveis climáticas.............................................. 26

3.2.4.2 Variáveis fisiológicas........................................... 28

3.2.4.3 Avaliação do Desempenho e Crescimento dos animais 30

3.2.4.4 Comportamento ................................................. 32

3.2.4.5 Variáveis qualitativas e quantitativas da carcaça........... 32

3.2.4.6 Indicativo Econômico .............................................. 36

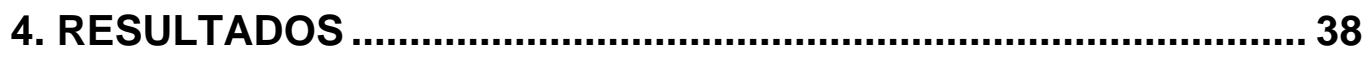

4.1 TELHA DE FiBRocimento............................................................ 38

4.1.1 Caracterização Física .................................................. 38

4.1.2 Caracterização Mecânica ............................................41

4.1.3 Desempenho Térmico ..............................................43

4.2 PROdUÇÃo DE VITELOS .............................................................. 44

4.2.1 Análise Física do Ambiente .........................................44

4.2.1.1 Gradiente Interno ............................................ 51

4.2.2 Desempenho Animal ................................................... 54

4.2.2.1 Desenvolvimento dos Animais ................................. 54

4.2.2.2 Variáveis Fisiológicas........................................ 57

4.2.2.3 Parâmetros Sangüíneos .......................................63 63

4.2.3 Variáveis Produtivas .......................................................64

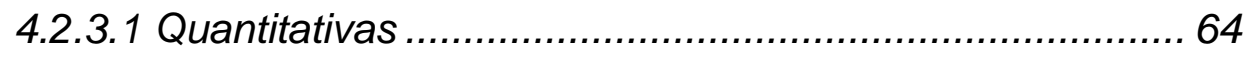

4.2.3.2 Qualitativas .................................................. 66

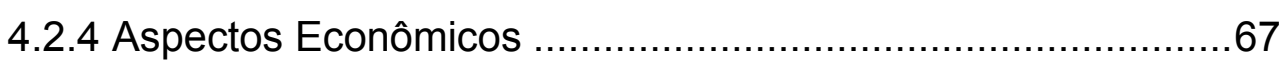

5. CONCLUSÕES ...................................................................... 70

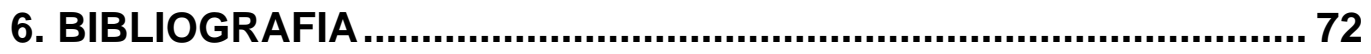




\section{LISTA DE FIGURAS}

FIGURA 1. Representação esquemática das zonas de sobrevivência, de bem-estar e homeotermia em condições ambientais para ruminantes. Adaptada de

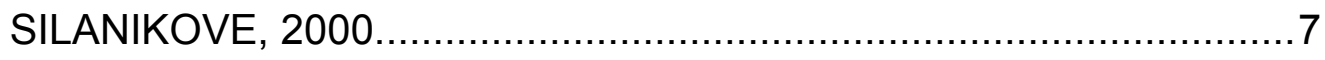

FIGURA 2. Telhas de fibrocimento sem amianto instaladas no sistema de cobertura.

FIGURA 3. Ensaio mecânico das telhas de fibrocimento reforçadas com fibra vegetal. 20

FIGURA 4. Sensor de temperatura instalado na superfície inferior da telha. .... 21

FIGURA 5. Representação esquemática das instalações estudadas .24

FIGURA 6. Animais utilizando o cocho de alimentação dotado do Sistema Calan Gate.

FIGURA 7. Esquema da disposição dos dataloggers instalados nas três alturas estudadas.

FIGURA 8. Coleta de sangue dos animais. 30

FIGURA 9. Coleta do perímetro torácico dos animais. 31

FIGURA 10. Pesagem dos animais.

FIGURA 11. Processo de abate dos animais. A - Evisceração; B - Divisão da carcaça; C - Pesagem e identificação das carcaças; D Armazenagem em câmara fria......

FIGURA 12. Carcaças protegidas com filme plástico.

FIGURA 13. Mensuração da área de olho de lombo (AOL), pelo método do plástico quadriculado.

FIGURA 14. Avaliação da cor apresentada pela carne de vitelo. 35 
FIGURA 15. Resultados da massa específica aparente $\left(\mathrm{g} / \mathrm{cm}^{3}\right)$ e erro-padrão das médias.

FIGURA 16. Resultados do volume aparente de vazios (\%) e erro-padrão das médias.

FIGURA 17. Resultado de absorção de água (\%) e erro-padrão das médias...... 41

FIGURA 18. Valores de força na ruptura $(N)$ e erro-padrão das médias. 42

FIGURA 19. Valores de energia específica $\left(\mathrm{J} / \mathrm{m}^{2}\right)$ e erro-padrão das médias. 43

FIGURA 20. Avaliação das médias da temperatura de superfície das telhas estudadas ao longo de 24 horas.

FIGURA 21. Médias da temperatura ambiente $\left({ }^{\circ} \mathrm{C}\right)$ e erro-padrão da média dos diferentes tratamentos.

FIGURA 22. Médias de umidade relativa (\%) e erro-padrão da média dos diferentes tratamentos.

FIGURA 23. Médias de temperatura de globo negro $\left({ }^{\circ} \mathrm{C}\right)$ e erro-padrão da média dos diferentes tratamentos.

FIGURA 24. Médias do índice de temperatura e umidade (ITG) e erro-padrão da média dos diferentes tratamentos.

FIGURA 25. Médias do índice de temperatura de globo e umidade (ITGU) e erropadrão da média dos diferentes tratamentos. .48

FIGURA 26. Média da carga térmica radiante $\left(\mathrm{W} / \mathrm{m}^{2}\right)$ e erro-padrão da média dos diferentes tratamentos. 50

FIGURA 27. Médias dos valores de entalpia (kJ/kg de ar seco) e erro-padrão da média dos diferentes tratamentos.

FIGURA 28. Médias da velocidade do vento $(\mathrm{m} / \mathrm{s})$ e erro-padrão da média dos diferentes tratamentos nas horas estudadas.

FIGURA 29. Gradiente de temperatura ambiente $\left({ }^{\circ} \mathrm{C}\right)$ no interior dos diferentes tratamentos estudados em função da altura em relação ao piso. 52

FIGURA 30. Gradiente de umidade relativa (\%) no interior dos diferentes tratamentos estudados, em função da altura em relação ao piso .53

FIGURA 31. Gradiente de temperatura de globo negro $\left({ }^{\circ} \mathrm{C}\right)$ no interior dos diferentes tratamentos estudados, em função da altura em relação ao piso. 
FIGURA 32. Gradiente de entalpia (kJ/kg de ar seco) no interior dos diferentes tratamentos estudados, em função da altura em relação ao piso.......54

FIGURA 33. Representação do comportamento ingestivo (\%IMS/período) dos animais por tratamento, durante os períodos avaliados.

FIGURA 34. Médias de temperatura retal $\left({ }^{\circ} \mathrm{C}\right)$ e erro padrão da média dos animais holandeses nos diferentes tratamentos nos horários avaliados. 58

FIGURA 35. Médias de temperatura retal $\left({ }^{\circ} \mathrm{C}\right)$ e erro padrão da média dos animais mestiços nos diferentes tratamentos nos horários avaliados. 58

FIGURA 36. Médias de temperatura de pele $\left({ }^{\circ} \mathrm{C}\right)$ e erro padrão da média dos animais holandeses nos diferentes tratamentos para os horários avaliados

FIGURA 37. Médias de temperatura de pele $\left({ }^{\circ} \mathrm{C}\right)$ e erro padrão da média dos animais mestiços nos diferentes tratamentos para os horários avaliados. 61

FIGURA 38. Médias de freqüência respiratória (mov/min) e erro padrão da média dos animais nos diferentes tratamentos em função dos horários avaliados.

FIGURA 39. Médias do peso de carcaça quente $(\mathrm{kg})$ e erro padrão da média dos grupos genéticos nos diferentes tratamentos.

FIGURA 40. Médias de porcentagem de carne na carcaça e erro padrão da média dos grupos genéticos nos diferentes tratamentos. 66

FIGURA 41. Médias dos valores de coloração na escala $a^{*}$ e erro padrão da média em função do grupo genético. 67 


\section{LISTA DE TABELAS}

TABELA 1. Composição química da escória de alto forno moída.

TABELA 2. Características físico-químicas da sílica ativa. .17

TABELA 3. Propriedades físicas das fibras celulósicas. 17

TABELA 4. Diferentes composições de fibras (em \%), para as diferentes séries estudadas. 18

TABELA 5. Descrição dos ingredientes presentes na ração. 23

TABELA 6. Análise bromatológica da ração utilizada no experimento. 23

TABELA 7. Índice de consistência encontrado para as diferentes séries. .38

TABELA 8. Dados meteorológicos do ambiente externo das instalações referentes ao período experimental. .44

TABELA 9. Investimentos realizados nos diferentes tratamentos. .68

TABELA 10. Custos de produção ( $R \$ / \mathrm{kg}$ de carne) por tratamento e por grupo genético. 69 


\section{RESUMO}

O objetivo deste estudo foi avaliar a influência de telhas de fibrocimento sem amianto e sistema de climatização, sobre a produção de vitelos mestiços e da raça holandesa. O experimento foi realizado de agosto de 2002 a março de 2003. Foram utilizados 16 animais mestiços Gir x Holandês, sem grau de sangue definido, e 11 animais da raça Holandês, P.O., com aproximadamente três meses de idade, no início do experimento, distribuídos em três tipos de instalação: com cobertura de telha de cimento amianto; com telha não convencional de cimento celulose, e com telha de cimento celulose e equipada com sistema de climatização. As variáveis coletadas dos animais, como altura de cernelha, perímetro torácico, ganho de peso, consumo alimentar individual e conversão alimentar, foram medidas a cada 14 dias para cada indivíduo. As variáveis fisiológicas, como temperatura de pele, temperatura retal e freqüência respiratória, foram mensuradas duas vezes ao dia, durante 23 dias. Ainda foram coletados registros dos parâmetros sangüíneos dos animais, bem como aspectos quantitativos e qualitativos das carcaças. Os dados climáticos de cada instalação foram registrados e posteriormente calculados os índices de conforto. Com relação aos índices de conforto, o efeito do tipo de cobertura foi significativo, mostrando como melhor ambiente aquele proporcionado pela cobertura de cimento celulose. Já para as variáveis temperatura ambiente e temperatura de globo negro, o que mais influenciou os resultados foi a presença ou não de climatização no ambiente; o melhor ambiente foi aquele com sistema de climatização. Os efeitos do ambiente nas repostas fisiológicas dos animais, mostraram que o melhor ambiente foi o climatizado, com menores valores para temperatura de pele, temperatura retal e freqüência respiratória. Apesar disso, não foram observadas diferenças no desempenho dos animais em relação ao tratamento, mas sim, em relação ao grupo genético. Com isso, comprovou-se um 
possível potencial de produção de vitelos a partir de animais mestiços. Esta resposta pode ser observada também na análise econômica, pela qual o custo de produção de carne de vitelo mestiço foi igual para todas as instalações. Os animais mestiços produzidos a partir das instalações cobertas com telhas de fibrocimento não convencional, tiveram custo de produção mais baixo que a carne de vitelos holandeses. 


\begin{abstract}
The aim of this study was to evaluate the influence of asbestos free fibercement tiles and cooling system for Holsteins and Crossbreeding veals. The experiment was carried out from August 2002 until March 2003. Sixteen crossbreeding Gyr x Holsteins veals, with undefined blood levels and eleven Holsteins veals were used in the work, all of them with approximately three months of age. The animals were studied into buildings with three different types of roofing: (i) asbestos corrugated sheet; (ii) fiber-cement tiles and (iii) fiber-cement tiles associated with cooling system. Height gain, heart girth gain, weight gain, dry matter intake and feed:gain ratio were measured in every 14 days. The physiological data such as skin surface temperature, rectal temperature and respiratory rate were measured twice a day during 23 days. Blood parameters, carcass quality and quantity data were also collected from each animal. Climatic data of each housing condition were recorded for the calculation of the comfort indexes. The physical analysis of the environment through out comfort index showed that the effect of the roofing type was significant and the best environment was the one with fiber-cement tiles. The presence or absence of the cooling system affected the air temperature and the black globe temperature. The best results were the ones associated with the cooling system. The cooled housing was the best environment for the physiological parameters of the animals, and it was connected with the lowest values for skin surface temperature, rectal temperature and respiration rate. Therefore, the animal performance did not show any difference in relation to the kind of housing. The difference in performance was significant between the two genetic groups, showing the potential of production of crossbreeding animals. Theses results can also be observed in the economical analysis. The production cost of the meat from crossbreeding veals was the same for all kinds of housing. In the case of housing
\end{abstract}


with fiber-cement tiles, the meat from crossbreeding veals had a lower production cost than the meat from Holstein veals. 


\section{INTRODUÇÃO}

A grande preocupação das pessoas com as elevadas taxas de colesterol no organismo, tem induzido a uma alimentação com carne bovina com menores índices de gordura. Essa possibilidade de atingir novos e promissores mercados, sobretudo o internacional, depende, porém, do empenho de todos os pecuaristas para a rápida modernização da criação nacional. O bezerro leiteiro representa um dos caminhos viáveis para isso.

Com a mudança no perfil do setor leiteiro no Brasil, bem como o emprego de tecnologias para aumentar a eficiência da exploração leiteira, cresce o número de animais machos, que podem ser destinados ao abate e cuja carne entra como fonte alternativa de renda para o produtor (RIBEIRO, 1997).

Nos países de pecuária leiteira desenvolvida, o aproveitamento dos bezerros de rebanhos leiteiros para a produção de carne é uma realidade e representa parcela significativa da carne consumida pela população (BOER, 1991). Na Holanda, na França e na Itália, principalmente, e, em menor escala, nos Estados Unidos da América e no Canadá, bezerros, predominantemente de raças leiteiras, são abatidos com 16 a 18 semanas de idade e 160 a $170 \mathrm{~kg}$ de peso vivo.

Anualmente, nas principais bacias leiteiras do Brasil, milhares de bezerros machos são sacrificados ao nascer, eliminando-se assim, uma fonte de renda em potencial. Os machos de raças leiteiras mais apuradas são sacrificados logo após o nascimento, pois, apesar de seu potencial para ganhar peso, não conseguem se adaptar às condições rústicas de um sistema de criação extensivo (ALLEONI et al., 1980; LUCCl, 1989). Quando não são sacrificados logo após o nascimento, são vendidos a preços irrisórios para abate. Esses animais resultam de uma ou mais inseminações ao custo médio 
de $R \$ 12,00$ e concorrem com as fêmeas por área, alimento e manejo (TOLEDO, 2001a).

A comercialização do sêmen sexado deverá estar disponível nos próximos 12 a 18 meses, porém, esta realidade terá viabilidade para produtores altamente especializados. O custo, segundo GILBERT (2004), será próximo de $\mathrm{R} \$ 140,00(\mathrm{U} \$ 50,00)$ a $\mathrm{R} \$ 165,00(\mathrm{U} \$ 60,00)$ a mais do custo de sêmen convencional.

Portanto, em termos gerais, o aproveitamento do macho leiteiro apresenta-se potencialmente como uma atividade adicional para o produtor de leite, sobretudo para médios e pequenos produtores, com geração de maior rentabilidade para a atividade.

A produção de vitelos deve estar relacionada à utilização racional de recursos, bem como com o oferecimento de condições adequadas para a expressão do seu potencial produtivo. Para isso, são desejáveis manejos e instalações que propiciem estas características (SAVASTANO, 1994).

A maior rentabilidade da atividade de criação do vitelo depende do oferecimento de instalações e manejo adequados para o animal, em especial nas regiões de clima tropical, principalmente ao se tratar de raças leiteiras especializadas, originárias da Europa. Para tanto, são desejáveis instalações adequadas que propiciem conforto térmico, além de estarem relacionadas a princípios de sustentabilidade da construção e serem economicamente viáveis.

Com a exigência de produtos saudáveis e de qualidade, além da criação dentro dos padrões de bem-estar animal, ressalta-se a importância da carne de vitelo (TOLEDO, 2001b). Trata-se de carne praticamente isenta de cobertura de gordura, macia e com moderado grau de marmorização.

O Brasil possui grande potencial para a produção de vitelo. Sendo assim, pesquisas que envolvam a produção de vitelos provenientes de rebanhos mestiços se fazem necessárias, já que a maioria do rebanho leiteiro nacional é de origem mestiça.

Diante do exposto, este trabalho teve como objetivos:

- Investigar e comparar o conforto térmico de instalações com diferentes tipos de coberturas, com e sem climatização, por meio de índices de conforto;

- Avaliar a possível influência do conforto proporcionado pelas diferentes instalações nos parâmetros produtivos e fisiológicos de vitelos; 
- Comparar a produção de vitelos da raça Holandesa com vitelos mestiços Holandês X Zebu;

- Apresentar indicativos relacionados à viabilidade econômica de cada tipo de instalação. 


\section{REVISÃO DE LITERATURA}

\subsection{Vitelo}

A busca pela melhoria da eficiência da produção de carne tem mudado o perfil da pecuária, partindo da posição de empreendimento extrativista, para patamares de intensificação total (EUCLIDES FILHO et al., 1996)

A utilização de machos leiteiros para a produção de carne é comum nos mercados da América do Norte e principalmente da Europa. O vitelo pode ser caracterizado pelo sistema de alimentação: (i) exclusivamente leite e sucedâneos até o abate, para produção de carne branca, e (ii) alimentação com leite e posteriormente com concentrados e fenos, com teores mínimos de ferro presentes na dieta, para produção do vitelo róseo (LUCCI, 1989).

De acordo com ALVES \& LIZIERE (2001), nos países de pecuária leiteira desenvolvida, a produção de vitelos cresce a cada ano, principalmente na Europa, na busca por carnes de coloração mais clara, tenra e própria para preparo de pratos sofisticados.

Porém, aspectos relacionados com o sistema de criação definem o vitelo e, por conseqüência, o preço. De acordo com MCKEITH \& WILSON (1994), os valores pagos às carcaças de vitelos dependem principalmente da sua coloração.

O vitelo com carne branca é abatido com $140 \mathrm{~kg}$ em média. Por outro lado, o vitelo com coloração de carne mais escura (vitelo róseo), também denominado vitelo tropical, é abatido com média de 170 a $220 \mathrm{~kg}$ e alimentado com predominância de sólidos, portanto, com custo de produção inferior (TOLEDO, 2001b).

Já USDA (1995) define o vitelo como o bovino imaturo destinado à produção de carne e apresenta uma classificação constituída por quatro grupos divididos de acordo com a faixa de peso vivo, que varia de 70 a $250 \mathrm{~kg}$. 
$\mathrm{Na}$ Europa, os sistemas de criação de vitelos normalmente incluem o animal de "carne branca", "carne rósea" e bezerros de engorda intensiva, com pesos de abate de 100 a $450 \mathrm{~kg}$ e idade de 3 a 12 meses (PEREZ REDONDO citado por RIBEIRO et al., 2001). Na sistemática americana, uma das classes, o vitelo não especial, recebe como alimentos o sucedâneo de leite, volumosos diversos e concentrados, podendo ser abatido com até $200 \mathrm{~kg}$. O correspondente no sistema europeu - o vitelo de carne rósea - é abatido aos 56 meses de idade, com 225 a $250 \mathrm{~kg}$ de peso vivo.

HEDRICK et al. (1994) relatam que a coloração é um fator importante para a seleção da carne a ser consumida. Com isso, a cor da carcaça é fundamental na criação de vitelos e os preços podem variar de até $30 \%$ de acordo com a sua tonalidade (MCKEITH \& WILSON, 1994). Porém, em termos gerais, o preço dos cortes de carne de vitelos é superior ao de outros tipos de carne, o que afeta diretamente a difusão e o consumo de vitelo (MCNEILL et al., 1998).

As indústrias de vitelo são importantes segmentos da economia agrícola em diversas áreas dos Estados Unidos. Aproximadamente 800.000 bezerros são utilizados anualmente em sistema de criação de vitelos róseos (SMITH et al., 1999). Apesar do grande número, o consumo de carne de vitelo nos Estados Unidos encontra-se em torno de $0,55 \mathrm{~kg} / \mathrm{habitante} / \mathrm{ano}$ em relação à carne de bovino adulto com consumo de $28,9 \mathrm{~kg} / \mathrm{habitante} /$ ano (USDA, 1996).

Já no caso do Brasil, a CODEAGRO (2002) relata que existe um potencial para produção de bezerros machos nas bacias leiteiras do Estado de São Paulo de 169.940 animais/ano.

\subsection{O Animal e o Ambiente}

$\mathrm{Na}$ Europa, a grande pressão pública está relacionada com o bem-estar na criação animal (BROOM, 1992). Pesquisas recentes na área de instalações e práticas de manejo, em propriedades rurais, intensificaram a discussão sobre o bem-estar animal. Os efeitos do estresse térmico sobre o manejo intensivo de bovinos têm sido demonstrados (YOUNG, 1993; JACOBSEN, 1996). De acordo com SILANIKOVE (1992), existe interação entre produtividade em sistemas intensivos e extensivos de criação de bovinos e estresse calórico. $O$ calor é o 
fator de redução da produtividade em regiões tropicais e também em regiões áridas.

Para o Brasil, o efeito do estresse térmico torna-se mais um agravante da produção animal, pois o país possui cerca de dois terços do seu território na faixa tropical do planeta com predomínio de altas temperaturas, conseqüência da elevada radiação solar incidente (TITTO, 1998). A temperatura média do ar se situa, em geral, acima dos $20^{\circ} \mathrm{C}$, e a temperatura máxima apresenta-se acima de $30^{\circ} \mathrm{C}$, na maior parte do ano, muitas vezes entre 35 e $38^{\circ} \mathrm{C}$. De acordo com SILVA et al. (1990), em climas tropicais e subtropicais, os valores de temperatura e umidade relativa do ar têm-se mostrado limitantes ao desenvolvimento, à produção e à reprodução de animais homeotermos.

Os animais homeotermos mantêm a temperatura corporal relativamente constante por meio de mecanismos fisiológicos e comportamentais ligados a termorregulação. Sob condições térmicas adequadas, a maioria dos ruminantes consegue manter equilíbrio entre produção e dissipação de calor. No entanto, sob condições de estresse térmico, o número de respostas fisiológicas e comportamentais varia em intensidade e duração, dependendo da genética e dos fatores ambientais (DAS et al., 1999). Estes limites são conhecidos e com eles é possível caracterizar a zona de conforto térmico para o animal em questão.

\subsubsection{Zona de Conforto}

A zona de conforto térmico é a faixa de temperatura na qual o animal homeotermo praticamente não utiliza seu sistema termorregulador, seja para fazer termólise ou termogênese, situação em que o gasto de energia para mantença é mínimo, e na qual ocorre a maior eficiência produtiva (TITTO, 1998). ROSENBERG et al., citados por BAÊTA \& SOUZA (1997), definiram essa faixa de temperatura como zona de indiferença térmica (zona de termoneutralidade), em que apenas o metabolismo normal fornece a energia necessária para manter a temperatura corporal no nível normal.

SILANIKOVE (2000) descreve esquematicamente a relação entre o animal e o ambiente, situando a zona de termoneutralidade, bem como os estágios relacionados com o bem-estar do animal (Figura 1). No estágio 1 é encontrada temperatura acima ou abaixo da temperatura ideal, porém, os 
mecanismos de termorregulação do animal são utilizados de forma eficiente, não apresentando efeitos sobre a produção. No estágio 2, os animais se tornam vulneráveis para interações negativas entre nutrição e estresse térmico como, por exemplo, diminuição do consumo de matéria seca e aumento da ingestão de água, quando a temperatura excede o limite superior (condição de estresse por calor). Para o estágio 3 , também denominado "estágio nocivo", a manutenção da homeotermia já não pode ser considerada eficiente. Há alterações na produção de calor metabólico e na temperatura corporal, atingindo diretamente a produção animal. Por fim, o estágio 4 (estágio extremo), em que podem ser encontradas mortes por estresse, seja por frio ou por calor.

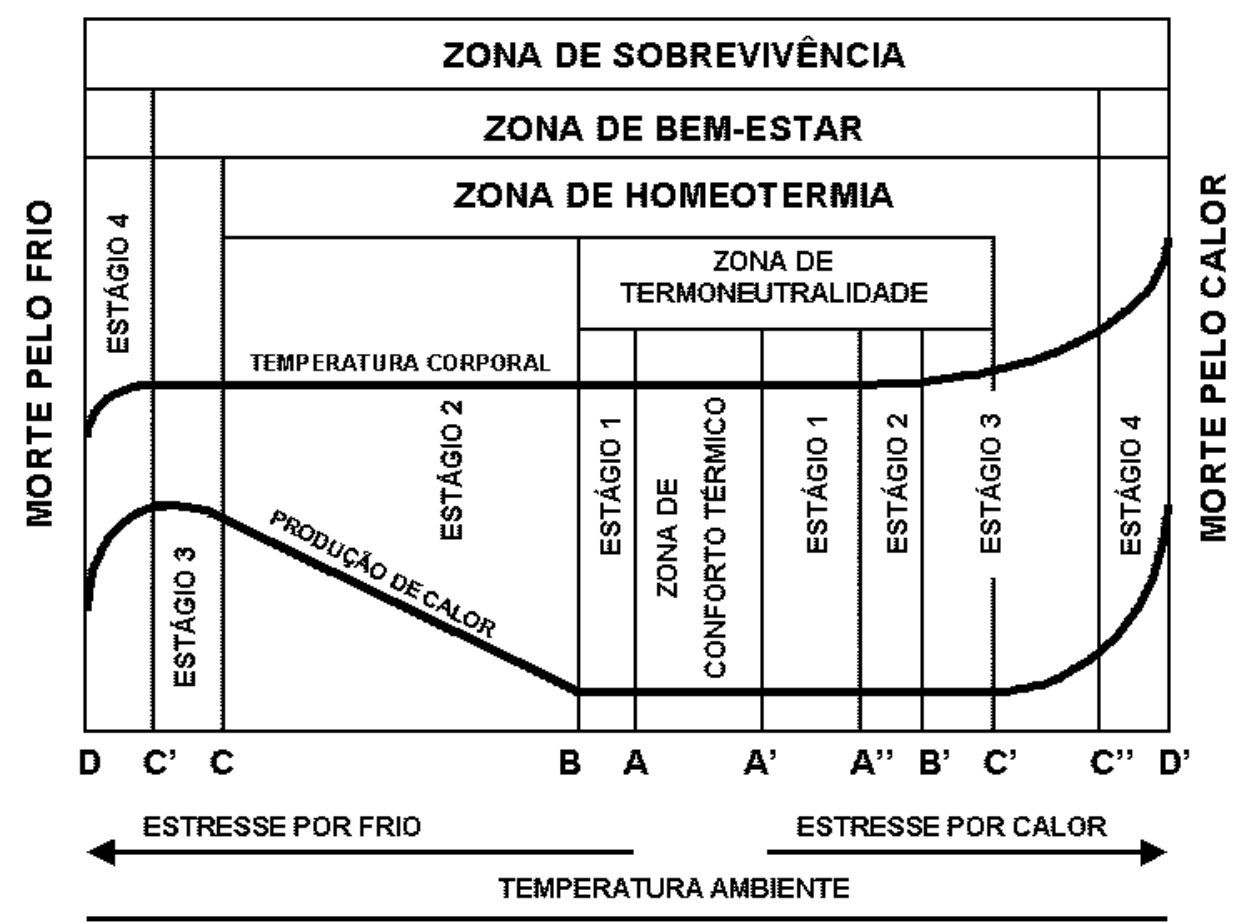

FIGURA 1. Representação esquemática das zonas de sobrevivência, de bemestar e homeotermia em condições ambientais para ruminantes. Adaptada de SILANIKOVE, 2000.

CURTIS (1983) e HAFEZ (1986), citados por BAÊTA \& SOUZA (1997), indicaram como zona de conforto para bovinos jovens, a faixa de 18 a $21^{\circ} \mathrm{C}$ (região ótima). BIANCA (1970); HAHN (1976), SALEM et al. (1982) adaptados 
por SILVA (2000), relatam a temperatura efetiva crítica inferior para bezerros de $13^{\circ} \mathrm{C}$, e temperatura efetiva crítica superior de $25^{\circ} \mathrm{C}$.

Com isso, alguns índices têm sido utilizados para predizer o conforto ou o desconforto das condições ambientais.

\subsection{2 Índices de Conforto}

CLARK (1981), afirmou que o objetivo dos índices de conforto térmico, tanto para humanos como para animais domésticos, era apresentar, em uma única variável, a síntese de diversos fatores que caracterizam o ambiente térmico e o estresse que possam causar.

Em climas quentes, as temperaturas elevadas, ação direta ou indireta da radiação solar, da velocidade do vento e da umidade relativa do ar, são fatores ambientais que podem provocar desconforto térmico para os animais ( $\mathrm{FINCH}$, 1984 citado por SILANIKOVE, 2000).

Os índices de conforto térmico, podem variar de uma simples mensuração de temperatura do ar, até equações de predição para quantificar a influência destes fatores no conforto térmico. A temperatura de globo negro combina os efeitos de radiação incidente do sol, do ambiente circundado, do solo e de outros objetos, com a temperatura do ar e a velocidade do vento (BOND \& KELLY, 1955).

$\mathrm{Da}$ associação da temperatura de globo negro com a temperatura de ponto de orvalho, BUFFINGTON et al. (1981) desenvolveram o índice de temperatura de globo e umidade - ITGU (Black Globe Humidity Index - BGHI). BAÊTA (1985) relata estudos realizados pelo National Weather Service - USA (1976), que mostram que valores de ITGU até 74 definem situação de conforto para os bovinos; de 74 a 78 , situação de alerta; de 79 a 85 , situação perigosa; e acima de 85 , emergência.

MCDOWELL et al. (1976) sugeriram o índice de temperatura e umidade - ITU (Temperature Humidity Index - THI) como outro indicador adequado de condições de estresse térmico. Esse índice foi desenvolvido THOM (1959) como indicativo de conforto térmico humano. Utilizando para descrever desconforto térmico em animais, CARGILL \& STEWART (1966) observaram quedas na produção de leite de vacas, associadas ao aumento no valor de ITU. 
ARMSTRONG \& WELCHERT (1994) descreveram que valores de ITU abaixo de 72 são considerados situação confortante para bovinos; entre 72 a 78, estresse ameno; de 79 a 88, estresse moderado; e de 89 a 98, estresse severo. Valores do índice acima de 98 são considerados situação desconfortante, sendo associados a mortes no rebanho.

Segundo SILANIKOVE (2000), o índice ITU é amplamente utilizado na maioria dos países, pela fácil aquisição de dados para seu cálculo, por meio de estações meteorológicas regionais.

ESMAY (1979) pesquisou outro índice de conforto térmico denominado Carga Térmica Radiante - CTR, que quantifica a radiação total pelo globo negro, de todo o espaço circundante. Para o cálculo deste índice, existe o envolvimento da temperatura radiante média (TRM). Para BOND \& KELLY (1955), TMR é a temperatura do ambiente circundante, considerado uniformemente negro para eliminar o efeito da reflexão, com o qual o corpo (globo negro) troca tanta quantidade de energia, quanto a do ambiente atual considerado.

\subsubsection{Respostas Fisiológicas}

A habilidade de regular a temperatura corporal, é uma adaptação evolutiva que os animais homeotermos possuem, em função da variação da temperatura ambiente (BAKER, 1989).

Segundo ARMSTRONG (1994), quando animais homeotermos, por exemplo os bovinos, têm esta habilidade prejudicada pelo desconforto térmico, respondem de várias maneiras, como redução do consumo de alimento, alteração da taxa metabólica e dos requerimentos para mantença, aumento da taxa respiratória, alteração da concentração de hormônios circulantes e aumento da temperatura corporal. YOUSEF (1985) citou ainda o incremento na freqüência respiratória. BLAZQUEZ et al. (1994) observaram ofegação, salivação excessiva e alta taxa de sudação.

A temperatura alta crônica age sobre o sistema endócrino e leva à hipofunção da tireóide, que influi no crescimento, na eficiência reprodutiva e na conversão alimentar (MÜLLER, 1989).

No Brasil, HISSATUGUE \& MACHADO (1977) citaram MILAGRES et al. (1971), que trabalharam com novilhas zebu e mestiças holandesas, e 
constataram ganhos de peso mais baixos durante os meses de temperatura ambiente elevada, principalmente para as novilhas holandesas de alto grau de sangue. CHIQUILOFF (1964) e BACCARI et al. (1971), citados por HISSATUGUE \& MACHADO (1977), informaram que o aumento de temperatura ambiente induz ao aumento de temperatura retal e freqüência respiratória.

HANCOCK \& PAYNE (1955) observaram que os bovinos europeus, se criados em regiões tropicais, apresentam crescimento mais lento e maturidade sexual retardada, o que reduz, conseqüentemente, a produção de leite e de carne.

VEIGA et al. (1964) relataram que, em bovinos das raças Holandesa, Jersey, Zebu e mestiços, a temperatura retal, a freqüência cardíaca e os movimentos respiratórios são mais elevados sob condições de calor, enquanto o número de glóbulos vermelhos e a taxa de hemoglobina são inferiores.

Quanto à composição sanguínea, BRODY (1949), BLINCOE \& BRODY (1951) e YOUSEF \& JOHNSON (1965) constataram diminuição da taxa de uréia e aumento dos níveis de creatinina sérica para vacas da raça Holandesa à temperatura de $32^{\circ} \mathrm{C}$. No entanto, Segundo BOSE (1964) e MENON et al. (1969), os valores de uréia sanguínea de bovinos estão relacionados com o tipo de alimentação. Para LUCCI (1989), temperaturas elevadas implicam desconforto e maior taxa de mortalidade, maiores concentrações de corticóides e menores teores de imunoglobulinas séricas, em comparação aos valores associados a animais sob temperaturas confortáveis.

Vários trabalhos com bovinos (DAVIS \& MERILAN, 1960; WELDI et al., 1964 e MODDY et al., 1967) descreveram o efeito do calor sobre o consumo de alimentos. MISRA et al. (1963) compararam algumas reações fisiológicas dos animais sob condições de sol e sombra, e observaram declínio do consumo de alimento para temperatura acima de $33^{\circ} \mathrm{C}$.

\subsection{Instalacões}

As instalações têm por objetivo, oferecer conforto ao animal e permitir que ele expresse seu potencial de produção. Devem ser construídas e planejadas com a finalidade principal de diminuir a ação direta do clima, que pode agir negativamente nos animais (SEVEGNANI et al., 1994). 
NÄÄS (1998) citou que as limitações dos índices zootécnicos, em países de clima quente, decorrem das dificuldades de animais, geneticamente desenvolvidos para produção em climas mais amenos, serem alojados em um clima diferente, como o clima tropical, sob condições ou conceitos provenientes de regiões temperadas. Daí a necessidade de instalações adaptadas, com características construtivas que garantam o máximo possível de conforto, e que permitam ao animal abrigado desenvolver todo seu potencial genético.

Um dos grandes problemas para a falta de adaptação das instalações, refere-se à influência dos tipos de cobertura sobre o conforto térmico de abrigos. De acordo com COSTA (1982), a insolação (radiação solar) é a principal geradora do desconforto térmico nas edificações. Além disso, ressalta que as causas do desconforto térmico em habitações, estão relacionadas basicamente, a temperatura e umidade relativa.

BAÊTA \& SOUZA (1997), reforçam o fato de que vários parâmetros do ambiente, podem favorecer ou prejudicar o desempenho animal, e assim, facilitar ou inibir os processos produtivos e reprodutivos. Atualmente, o manejo do ambiente tem sido amplamente difundido. Os mesmos autores discutem as várias estratégias para remediar os problemas existentes na relação animalambiente. Isto significa a modificação do ambiente, para atenuar a ação de fatores danosos aos animais.

\subsubsection{Coberturas}

SILVA et al. (1990) estudaram a influência dos telhados no conforto térmico das instalações.

TOLEDO (1970), citado por SILVA et al. (1990), pesquisou as causas do desconforto térmico em construções residenciais, e concluiu que, o fluxo de calor através das coberturas, juntamente com as temperaturas elevadas na face inferior das telhas, pode vir a ser a causa principal do desconforto térmico no interior das residências.

De acordo com COSTA (1982), a proteção contra a insolação direta sob coberturas, pode ser feita pelo uso de coberturas com poder refletivo elevado, forros, isolantes térmicos e materiais de grande inércia térmica.

ROSA (1984) observou a influência de três materiais de cobertura no conforto térmico de instalações em condições de verão. Concluiu que as 
melhores condições de conforto térmico foram obtidas em ambiente sob cobertura de cerâmica, seguido por ambiente sob cobertura de alumínio. O pior desempenho esteve associado ao ambiente sob cobertura de cimento amianto.

Porém, apesar do desempenho inferior, o cimento amianto é ainda amplamente utilizado, sendo empregado em 56\% das caixas d'águas e 49\% dos telhados brasileiros, segundo informação da Associação Brasileira das Indústrias e Distribuidores de Fibrocimento (Abifibro) de 2001. Seu manuseio pode causar problemas pulmonares, inclusive câncer. Além disso, tem grande capacidade de poluir o ambiente (CAMPANILLI, 2003).

No que se refere à preocupação com o meio ambiente, a geração de resíduos se torna um componente obrigatório. No entanto, quando o resíduo passa a ser valorizado, este se torna matéria-prima para obtenção de novos produtos. Neste caso, o resíduo passa a ser tratado como subproduto do processo produtivo (VALLE, 1995). Em países tropicais, os resíduos gerados pela agroindústria da fibra vegetal, podem constituir importante fonte de matéria-prima para a produção de componentes construtivos, dependendo das quantidades disponíveis e da dispersão geográfica, haja vista os custos de coleta e transporte (JOHN, 1997).

GUIMARÃES (1990) e AGOPYAN (1991) relataram diversas experiências sobre o uso de matrizes à base de cimento reforçado com fibras naturais, no Brasil, para produção de componentes construtivos, como telhas, painéis de vedação vertical, caixas d'água e pias de cozinha. Em todo o mundo, esses fibrocimentos alternativos já fazem parte de programas de transferência tecnológica, especialmente para sistemas de cobertura de baixo custo, como reportado por SAXENA et al. (1992), GRAM \& GUT (1994) e DELVASTO et al. (1995).

Trabalhos conduzidos no Instituto de Pesquisas Tecnológicas do Estado de São Paulo (IPT), mostraram que, as temperaturas efetivas de casas cobertas com telhas de fibrocimento, com áticos ventilados, foram menores do que em casas com telha de barro tipo francesa sem forro (ETERNIT, 1981).

A fabricação de telhas de fibrocimento sem amianto, a partir de matérias-primas de custo reduzido e por meio de processo alternativo e em pequena escala, tem sido desenvolvida pelo Grupo de Construções Rurais da FZEA (CUNHA et al., 2001 e SAVASTANO JÚNIOR, 2000). Esses estudos 
empregaram escória de alto-forno como aglomerante alternativo, e fibras residuais de sisal, coco e eucalipto como reforço. O desempenho físico e mecânico das telhas demonstraram seu potencial para construção rural, como moradias e abrigos para animais. Experimentos aplicados, em escala real, constituem etapa importante da transferência tecnológica do sistema construtivo como um todo. Estudos relacionados à durabilidade das telhas ainda estão em andamento.

LEE (2000) afirma que é considerável o uso de fibrocimentos nas coberturas de instalações pelo seu custo reduzido em comparação a outras soluções disponíveis para substituição de coberturas de cimento amianto.

\subsubsection{Modificações do Ambiente}

Segundo BACCARI JÚNIOR (1998), para a redução dos efeitos do estresse térmico e, assim, para a melhora da produção e do desempenho reprodutivo, recomendam-se algumas estratégias de manejo ambiental, entre as quais a provisão de sombra e de ventilação, bem como o resfriamento pela água, além de sistemas conjugados.

Em trabalho realizado por WIERENGA (1987), a redução do espaço disponível para bovinos em crescimento reduz o tempo em que o animal se encontra deitado, além de se observar maior incidência de comportamento agressivo dos animais.

A preocupação com o sombreamento de produção animal a pasto, em confinamento ou em regime semi-estabulado, aumenta à medida que esse sistema de criação é acompanhado da utilização de animais altamente especializados, que são muito sensíveis a altas temperaturas ambientes. A melhor sombra é proporcionada pelas árvores, isoladas ou em grupos (SILVA, 1988 citado por BACCARI JÚNIOR, 1998). Porém, na ausência dessas, lançase mão de sombras artificiais, que podem ser do tipo móvel ou permanente. A móvel, como a tela de fibra sintética (polietileno), em conjunto com estruturas simples de metal ou de madeira, pode prover de 30 a $90 \%$ de sombra, de acordo com a abertura da rede. Já a permanente pode utilizar telha cerâmica, de chapa de aço galvanizado ou de alumínio. HEAD (1995), afirmou que, a construção da estrutura permanente apresentava-se com custo mais elevado, comparada à móvel, e que esta última, por sua vez, possuía durabilidade entre 
cinco e dez anos. Para regimes de semi-estabulação, pode-se usar cobertura fixa sobre a área de cocho.

A ventilação adequada é de extrema importância numa instalação, pois é responsável por remoção da umidade, dispersão dos gases e do excesso de calor. Para épocas frias, quando se deseja manter o calor dentro das instalações, a ventilação deve ser adequada apenas para renovação do ar, para eliminação de gases e umidade (SILVA, 1998). O mesmo autor relata que, nas situações em que a temperatura ambiente for superior à ótima, é necessário aumentar a taxa de ventilação, a fim de eliminar o calor produzido pelos animais e evitar temperatura excessiva dentro das instalações.

Porém, recomenda-se cautela quanto à ventilação, pois, de acordo com MULLER (1989), a velocidade máxima do vento perto dos animais confinados não deve ultrapassar $0,2 \mathrm{~m} / \mathrm{s}$. Se ultrapassar esse valor, problemas pulmonares surgirão. De acordo com SILVA (1998), a localização dos ventiladores deve ser adequada para a maior eficiência do sistema.

LUCCI (1989) observa que, na ausência de boas condições para troca de ar em ambientes para criação de bezerros leiteiros, deve-se adotar a ventilação forçada, sempre que o espaço for inferior a $7,3 \mathrm{~m}^{3}$ por cabeça.

A associação de baixa umidade relativa do ar com alta temperatura, bem como de alta umidade relativa do ar com baixa temperatura, aumenta a susceptibilidade dos bezerros a moléstias respiratórias (LUCCI,1989).

O uso da água como alternativa de modificação do ambiente, e para oferecimento de conforto aos animais, é de grande importância. BACCARI JÚNIOR (1998) citou o uso da água como excelente agente resfriador, em razão da sua alta capacidade calórica. Ao passar do estado líquido para o gasoso, a água retira do ambiente cerca de $584 \mathrm{kcal} / \mathrm{kg}$ de água evaporada, dependendo da temperatura do ambiente (LEE \& SEARS, 1992).

Existem vários métodos para o uso da água, como nebulização, aspersão, lagoas de resfriamento, entre outros, citados por BRAY et al. (1992). Porém muito do uso da água está relacionado à ventilação, em sistemas conjugados, denominados sistemas de resfriamento evaporativo. Para WHITAKER (1979), citado por SILVA (1998), a eficiência da aplicação do sistema de resfriamento evaporativo depende da diferença entre as temperaturas de bulbo seco e úmido típicas de cada região. WHITAKER 
(1979), citado por SILVA (1998), relatou que o uso desse sistema permitiu queda de 4 a $7^{\circ} \mathrm{C}$ na temperatura em uma região dos Estados Unidos Unidos, o que correspondia à diferença entre as temperaturas de bulbo seco e úmido, ao meio dia, de 7 a $9^{\circ} \mathrm{C}$. Em outra região, a redução da temperatura foi de 8 a $11^{\circ} \mathrm{C}$, o que corresponde à diferença entre as temperaturas de bulbo seco e úmido de 14 a $17^{\circ} \mathrm{C}$.

SILVA (1998), relatou que, a eficiência dos sistemas de resfriamento evaporativo é maior nas regiões de clima quente e seco. Devem ser tomados os cuidados necessários com diferentes manejos, principalmente em regiões úmidas.

Em relação ao sistema de resfriamento evaporativo, SILVA (1998) destaca exemplos como a nebulização associada à ventilação, a aspersão de água sobre a cobertura, ou ainda, o uso de chuveiros para as vacas no campo ou na pós ordenha.

O sistema de nebulização associado com a ventilação, acelera a evaporação, também evita que a pulverização ocorra em um só local e molhe a cama (SILVA, 1998). Neste sistema há um gasto menor de água que cai sobre a vaca ou diretamente no chão. Todavia, a nebulização constante tende a manter a atmosfera saturada de vapor, o que dificulta as trocas térmicas por evaporação nos animais. Isso reitera a importância da intermitência do sistema de nebulização colocado na instalação.

ROMA JÚNIOR et al. (2001), ao avaliarem o efeito do sistema de nebulização de alta pressão sobre o ambiente físico de um free-stall, concluíram que a temperatura de globo negro do ambiente, com sistema de nebulização, foi de 1 a $1,5^{\circ} \mathrm{C}$ inferior em relação à instalação controle, sem alteração significativa da umidade relativa.

A aplicação de água, de diferentes formas, como agente resfriador, para aliviar o estresse térmico das vacas e aumentar a sua produção, é recomendada nas horas mais quentes do dia, à sombra; se a temperatura do ar ultrapassar $26-27^{\circ} \mathrm{C}$ e a umidade relativa do ar não for elevada (abaixo de 70\%). A intermitência de acionamento do sistema é variável e deve ser economicamente viável. Assim, seu uso deve ser controlado, para que se evite desperdício. (BACCARI JÚNIOR, 1998) 


\section{MATERIAL E MÉTODOS}

\subsection{Telhas de Fibrocimento}

\subsubsection{Produção das Telhas de Cimento Celulose}

Foram fabricadas, durante o experimento, 1500 telhas, com matriz à base de Cimento Portland CPII $32 Z$ (ABNT NBR-5735); escória de alto-forno (EAF) e sílica ativa, reforçadas com fibras de polpa celulósica de eucalipto (Eucalyptus grandis) residual e/ou sisal (Agave sisalana), de acordo com DEVITO (2003). As características químicas e físicas da EAF, da sílica ativa e das fibras são apresentadas nas Tabelas 1,2 e 3 respectivamente. A proporção dos componentes da matriz se manteve constante, para todas as telhas, a saber (\% em massa em relação ao total de sólidos do compósito): $59 \%$ de cimento CPII 32Z, 36\% de EAF e 5\% de sílica ativa. Em adicional ao total da massa sólida da matriz, foi acrescentado $3 \%$ de aditivo superplastificante. A relação água:aglomerante variou de 0,55-0,65 para a obtenção do índice de consistência (flow-table, ABNT NBR-7215) entre 210$250 \mathrm{~mm}$, para a massa recém misturada do compósito. Essa foi a faixa de valores considerados aceitáveis para facilitar a moldagem (DEVITO, 2003). 
TABELA 1. Composição química da escória de alto forno moída.

\begin{tabular}{lc}
\hline Composição & \% em massa \\
\hline Perda ao fogo & 1,67 \\
$\mathrm{SiO}_{2}$ & 33,78 \\
$\mathrm{Al}_{2} \mathrm{O}_{3}$ & 13,11 \\
$\mathrm{Fe}_{2} \mathrm{O}_{3}$ & 0,51 \\
$\mathrm{CaO}$ & 42,47 \\
$\mathrm{MgO}$ & 7,46 \\
$\mathrm{SO}^{3}$ & 0,15 \\
$\mathrm{Na}_{2} \mathrm{O}$ & 0,16 \\
$\mathrm{~K}_{2} \mathrm{O}$ & 0,32 \\
$\mathrm{~S}_{2}$ & 1,14 \\
CaO livre & 0,10 \\
Resíduo Insolúvel & 0,53 \\
\hline
\end{tabular}

Fonte: OLIVEIRA, 2000

TABELA 2. Características físico-químicas da sílica ativa.

\begin{tabular}{cr}
\hline Características Físicas & \\
\hline Diâmetro Médio $(\mu \mathrm{m})$ & 0,5 \\
Superfície Específica $\left(\mathbf{m}^{2} / \mathbf{g}\right)$ & 22,5 \\
Atividade Pozolânica $(\mathbf{m g} / \mathbf{g})$ & 813,83 \\
Densidade Real $\left(\mathbf{g} / \mathbf{c m}^{3}\right)$ & 2,65 \\
Fase & Amorfa \\
\hline Características Químicas & Concentração $(\%)$ \\
\hline $\mathrm{SiO}_{2}$ & 91,20 \\
$\mathrm{Al}_{2} \mathrm{O}_{3}$ & 0,22 \\
$\mathrm{Fe}_{2} \mathrm{O}_{3}$ & 0,56 \\
$\mathrm{Na}_{2} \mathrm{O}$ & 0,25 \\
$\mathrm{~K}_{2} \mathrm{O}$ & 0,68 \\
$\mathrm{CaO}$ & 0,22 \\
$\mathrm{H}_{2} \mathrm{O}$ & 0,30 \\
$\mathbf{P e r d a}$ ao fogo & 1,30 \\
\hline Fonte:
\end{tabular}

Fonte: Laboratório de Microestrutura, Escola Politécnica/USP.

TABELA 3. Propriedades físicas das fibras celulósicas.

\begin{tabular}{lcc}
\hline CARACTERÍSTICAS & $\begin{array}{c}\text { Eucalipto } \\
\text { (Eucalytpus grandis) }\end{array}$ & $\begin{array}{c}\text { Sisal } \\
\text { (Agave sisalana) }\end{array}$ \\
\hline Comprimento Médio $(\mathbf{m m}){ }^{*}$ & 0,660 & 1,660 \\
Espessura $(\mu \mathrm{m}){ }^{*}$ & 10,900 & 13,500 \\
Relação de Aspecto $* *$ & 61,000 & 123,000 \\
Coarseness $(\mathrm{mg} / \mathrm{m}) * * *$ & 0,107 & 0,163 \\
\hline
\end{tabular}

Fonte: SAVASTANO JÚNIOR, 2000

${ }^{*}$ ) Erro padrão equivalente a $50 \%$ da média dos valores.

$\left({ }^{* *}\right)$ Média do comprimento:espessura.

$\left.{ }^{* * *}\right)$ Massa por unidade de comprimento.

A Tabela 4, mostra os diferentes teores de fibra usados no preparo do compósito: 3 a $5 \%$ em relação à massa total de sólidos, equivalente a aproximadamente 2 a 3,5\% em volume do compósito. Foi seguida uma ordem para a mistura das matérias-primas, para a obtenção de ótima homogeneidade 
da massa, a saber: (i) dispersão da sílica ativa na quantidade total de água a ser utilizada, por um período de $60 \mathrm{~min}$ em agitador de eixo vertical com rotação de 1700 RPM, (ii) mistura do cimento CP ॥ $32 Z$ e da EAF em betoneira por $5 \mathrm{~min}$, (iii) adição da mistura líquida preparada no passo "i" e então misturada a massa por $10 \mathrm{~min}$, (iv) introdução das fibras e mistura por $5 \mathrm{~min}$. A produção das telhas utilizou equipamento com base no processo Parry Associates (Reino Unido), para moldagem e compactação por vibração. As dimensões para as telhas são $487 \times 263 \times 6 \mathrm{~mm}$ (medidas da fôrma) e de formato parecido com telhas cerâmicas estilo Romana (SAVASTANO JÚNIOR \& PIMENTEL, 2000 e GRAM \& GUT, 1994). Aproximadamente 24 h após a moldagem, as telhas eram tiradas dos moldes e submetidas a cura saturada por imersão em água durante 7 dias. Todo 0 processo produtivo aqui apresentado, faz parte de pedido de patente depositado por SAVASTANO JÚNIOR (2002). Para as séries testadas aos 28 dias de idade, as telhas foram mantidas em ambiente laboratorial até a caracterização física e mecânica. As telhas avaliadas aos 155 dias de idade foram transferidas para um sistema de cobertura imediatamente após o processo de cura. O sistema de cobertura, ilustrado na Figura 2, foi utilizado durante 148 dias, entre dezembro de $2002 \mathrm{e}$ março de 2003, até a realização dos testes físicos e mecânicos. Todas as telhas foram saturadas em água por $24 \mathrm{~h}$ antes da realização dos testes mecânicos.

TABELA 4. Diferentes composições de fibras (em \%), para as diferentes séries estudadas.

\begin{tabular}{llccc}
\hline Série & & E & ES & S \\
\hline \multirow{2}{*}{ Fibra } & Eucalipto & 5,0 & 2,0 & - \\
\cline { 2 - 5 } & Sisal & - & 1,0 & 3,0 \\
\hline
\end{tabular}




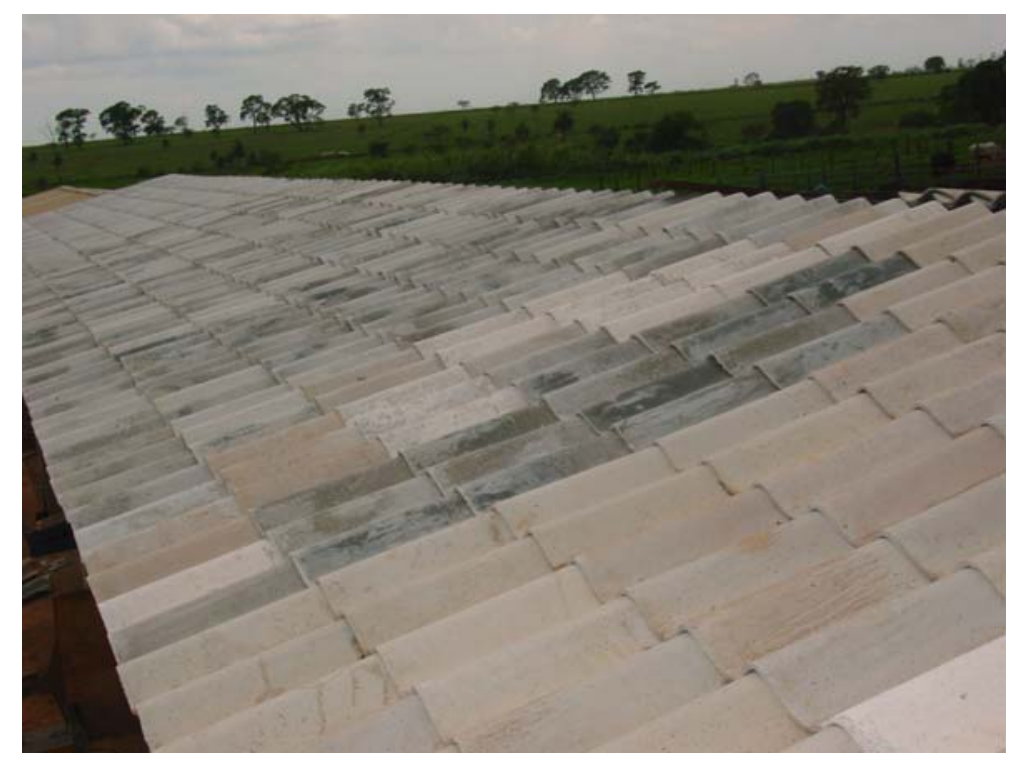

FIGURA 2. Telhas de fibrocimento sem amianto instaladas no sistema de cobertura.

\subsubsection{Caracterização das Telhas de Cimento Celulose}

As telhas foram caracterizadas no que se refere às suas propriedades físicas e mecânicas.

\subsubsection{Propriedades Físicas}

As propriedades físicas avaliadas foram: massa específica (Equação 1), absorção de água da telha (Equação 2) e volume aparente de vazios (Equação 3 ), obtidas pela média dos valores de seis corpos-de-prova (fragmentos de telha).

Os fragmentos foram pesados em balança digital com dispositivo hidrostático e com sensibilidade de $0,01 \mathrm{~g}$. As propriedades físicas foram calculadas a partir das massas: (i) seca em estufa por $24 \mathrm{~h}$ a $105^{\circ} \mathrm{C}$ (MSE), (ii) saturada com superfície seca após imersão em água por 24 h (MSS) e (iii) imersa (MIM).

$$
\begin{aligned}
& \text { Massa específica }=\frac{\text { MSE }}{\text { MSE - MIM }} \\
& \text { Absorção }=\frac{\text { MSS - MSE }}{\text { MSE }}
\end{aligned}
$$


Volume aparente de vazios $=\frac{\text { MSS }- \text { MSE }}{\text { MSS }- \text { MIM }}$

onde: MSE: massa seca em estufa por $24 \mathrm{~h}$ a $105^{\circ} \mathrm{C}$;

MIM: massa imersa;

MSS: massa saturada com superfície seca.

\subsubsection{Propriedades Mecânicas}

As propriedades mecânicas foram determinadas pelo ensaio de flexão com três cutelos (vão inferior de $350 \mathrm{~mm}$ ), para determinação do carregamento máximo e da energia específica dos compósitos. Foi utilizado máquina universal de ensaios EMIC DL 30000, com velocidade de carga (deslocamento do braço da prensa) de $0,5 \mathrm{~mm} / \mathrm{min}$ (Figura 3). A média de cada série foi calculada a partir dos resultados de seis corpos-de-prova (telhas).

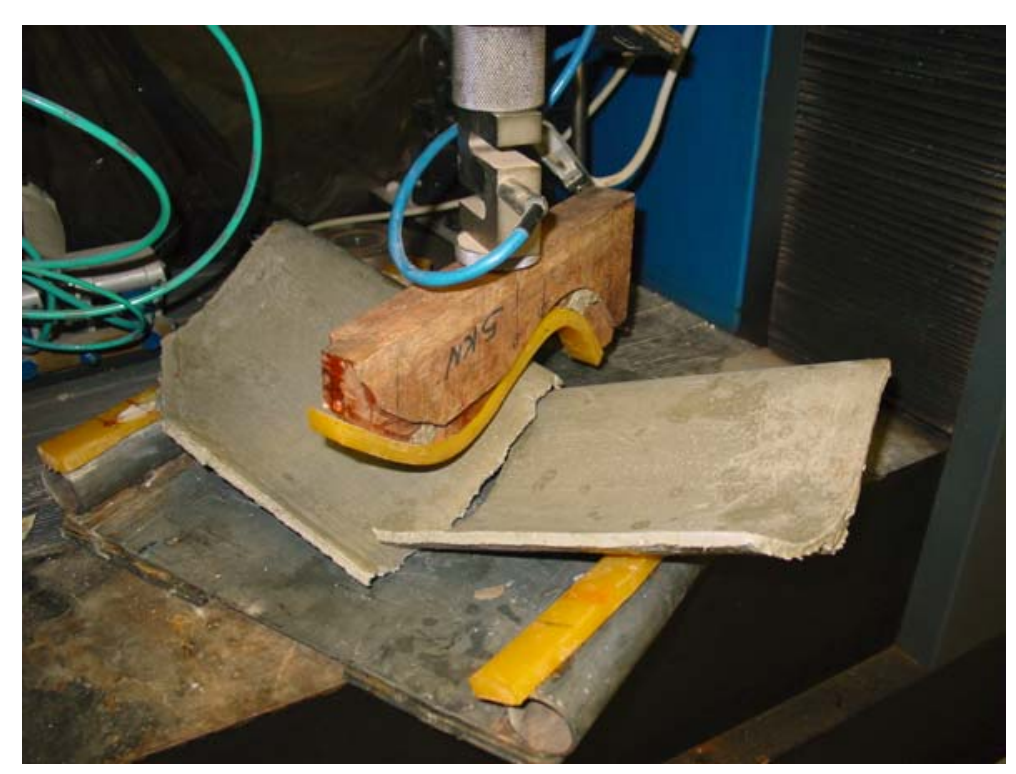

FIGURA 3. Ensaio mecânico das telhas de fibrocimento reforçadas com fibra vegetal.

Um computador munido do software M-Test (versão 1.01/96) foi utilizado para aquisição dos dados. Utilizou-se célula de carga com capacidade de $5 \mathrm{kN}$.

A energia específica do compósito, foi obtida pela relação entre a energia de fratura e a área da seção transversal da telha na região da fratura, conforme Equação 4. A energia de fratura é obtida da integração da área 
abaixo da curva carga versus deslocamento, até o ponto de redução de $50 \%$ da carga máxima aplicada.

$$
\text { Energia específica }=\frac{\text { Energia }}{\text { Área da secção transversal }}
$$

\subsubsection{Avaliação do Desempenho Térmico das Telhas}

Foram coletados valores da superfície inferior das telhas em um período de 23 dias não consecutivos, durante o verão, com auxílio de um sensor Onset HOBO, modelo TMC1 - HA, com faixa de leitura entre $-40^{\circ} \mathrm{C}$ a $+100^{\circ} \mathrm{C}$, acoplado em um datalogger da marca Onset $\mathrm{HOBO}^{\circledR}$, modelo $\mathrm{H} 8$, programado para coletar os dados a cada $15 \mathrm{~min}$, durante as 24 horas do dia. Teve-se o cuidado de proteger o sensor por uma camada de isopor para evitar a influência da temperatura ambiente (Figura 4). No experimento foram comparadas telhas de fibrociment,o reforçadas com fibra vegetal (série $S$ ) em relação à telha de cimento amianto.

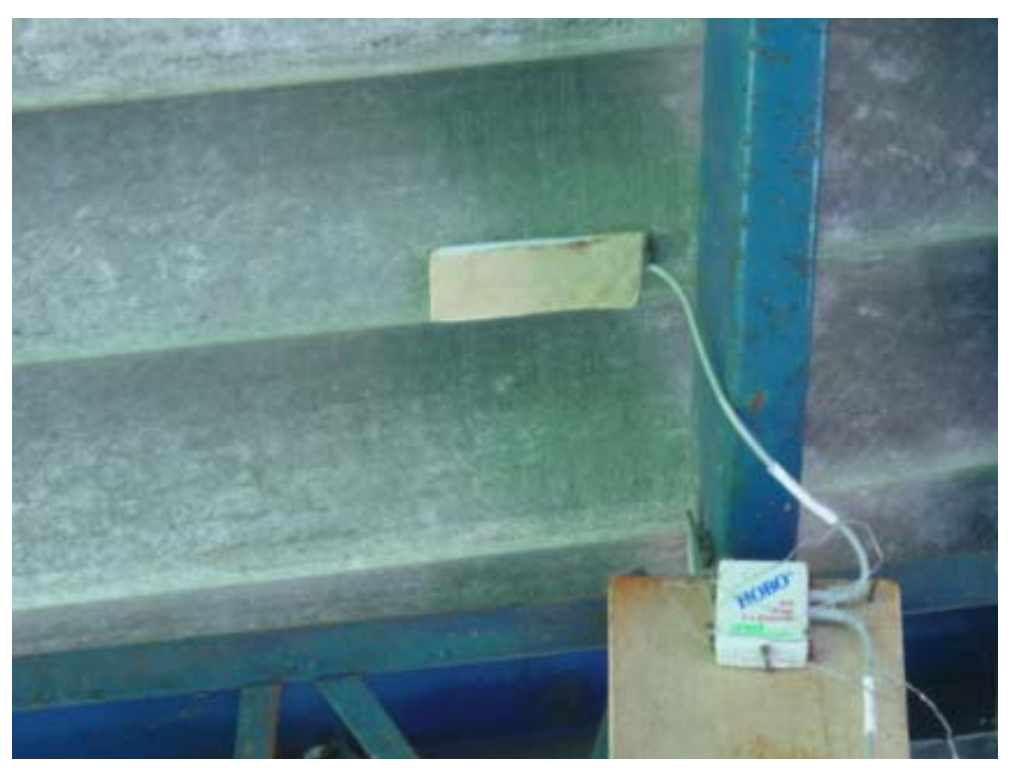

FIGURA 4. Sensor de temperatura instalado na superfície inferior da telha.

\subsubsection{Análise Estatística}

As propriedades físicas e mecânicas das telhas foram analisadas, com delineamento inteiramente casualizado, pelo procedimento GLM (General 
Linear Model), do programa $\mathrm{SAS}^{\circledR}$ (SAS, 1998), com a significância de $1 \%$ no teste Tukey.

\subsection{Produção de Vitelos}

\subsubsection{Local}

O trabalho foi realizado no setor de Bovinocultura de Corte da Prefeitura do Campus Administrativo da Universidade de São Paulo em Pirassununga (PCAPS), com início no dia 15 de dezembro de 2002 e término em 17 de março de 2003. O período de adaptação dos animais às instalações foi realizado entre 15 e 27 de dezembro de 2002. O município de Pirassununga encontra-se na altitude de $630 \mathrm{~m}$, e coordenadas $21^{\circ} 57^{\prime} 02^{\prime \prime}$ de latitude Sul e $47^{\circ} 27^{\prime} 50$ " de longitude Oeste. O clima da região é do tipo Cwa do Köeppen, tropical, sazonal, com duas estações bem definidas, verão chuvoso (outubro a março) e inverno seco (abril a setembro), com raras ocorrências de geadas. A temperatura média anual é de $22^{\circ} \mathrm{C}$ e a pluviosidade média anual é próxima a 1363 mm (SAVASTANO JÚNIOR, 2001).

\subsubsection{Animais}

Foram utilizados 16 bezerros mestiços Holandês x Zebu, sem grau de sangue definido e 11 bezerros da raça Holandês P.O., com idade aproximada de 100 dias no início do experimento. O peso inicial médio dos bezerros mestiços foi de $63,3 \mathrm{~kg}$ e dos bezerros holandeses, de $74,1 \mathrm{~kg}$. Para cada tratamento (instalação), foram distribuídos, por sorteio, animais das duas categorias, a saber:

- Instalação com cobertura de telhas de cimento amianto (controle): 5 Mestiços e 4 Holandeses. (ICA)

- Instalação com cobertura de telhas de fibrocimento alternativo (sem amianto): 6 Mestiços e 3 Holandeses. (IFB)

- Instalação com cobertura de telhas de fibrocimento alternativo (sem amianto e sistema de climatização: 5 Mestiços e 4 Holandeses. (IFC)

Houve oferecimento de ração ad libitum em todas as instalações, uma vez ao dia, às $7 \mathrm{~h}$ da manhã, durante todo o período do experimento. A 
composição da ração foi igual para todos os tratamentos, com relação volumoso:concentrado de 15:85, balanceada a partir dos dados recomendados pelo programa computacional Ração Lucro Máximo (RLM 2.0). A descrição e a composição do concentrado podem ser observadas na Tabela 5 e a análise bromatológica da ração, na Tabela 6.

TABELA 5. Descrição dos ingredientes presentes na ração.

\begin{tabular}{|l|r|}
\hline Ingredientes & \% da Matéria Seca \\
\hline Feno de Cynodon & 10,00 \\
\hline Milho (grão seco) & 33,57 \\
\hline Casca de soja & 38,09 \\
\hline Farelo de soja (49\%) & 17,33 \\
\hline Sal mineral & 0,99 \\
\hline Rumensina & 0,02 \\
\hline Total & $\mathbf{1 0 0 , 0 0}$ \\
\hline
\end{tabular}

TABELA 6. Análise bromatológica da ração utilizada no experimento.

\begin{tabular}{|l|r|}
\hline Composição Bromatológica & \\
\hline Matéria Seca (\%) & 95,5 \\
\hline Proteína Bruta * & 17,4 \\
\hline Fibra Bruta * & 28,2 \\
\hline Fibra em Detergente Neutro * & 45,7 \\
\hline Extrato Etéreo * & 2,6 \\
\hline Cálcio * & 0,4 \\
\hline Fósforo * & 0,3 \\
\hline * resultados expresso com base na matéria seca a 100\%. \\
FONTE: Laboratório de Nutrição, FZEA/USP, Pirassununga - SP.
\end{tabular}

\subsubsection{Instalações}

Os três tipos de instalações estudados apresentavam características iguais no que se refere ao dimensionamento e à estrutura construtiva da área de cocho, a saber: pé-direito igual a 3,5 m, área de cocho coberta de 4,0 × 10,0 $\mathrm{m}$ acessível para os animais, telhado tipo duas águas e piso de concreto de cimento Portland. Encontrava-se ainda acessível para os animais a área descoberta de 2,0 $\times$ 10,0 m, com piso de concreto. A Figura 5 apresenta de forma esquemática, o posicionamento e as dimensões das instalações utilizadas no experimento. Os cochos eram equipados com sistema de portão eletrônico, do tipo Calan Gate (Calan Gate Systems Inc.), que permitia a cada animal tivesse acesso somente a um determinado portão. 
O sistema de portões eletrônicos, consistia em que cada animal recebia um colar onde continha um dispositivo eletrônico, que, ao encostar no portão, acionava a trava somente daquele portão, permitindo o acesso do animal ao alimento. Esse sistema, presente nos três tratamentos, permitiu o controle do consumo alimentar individual, conforme demonstrado na Figura 6.

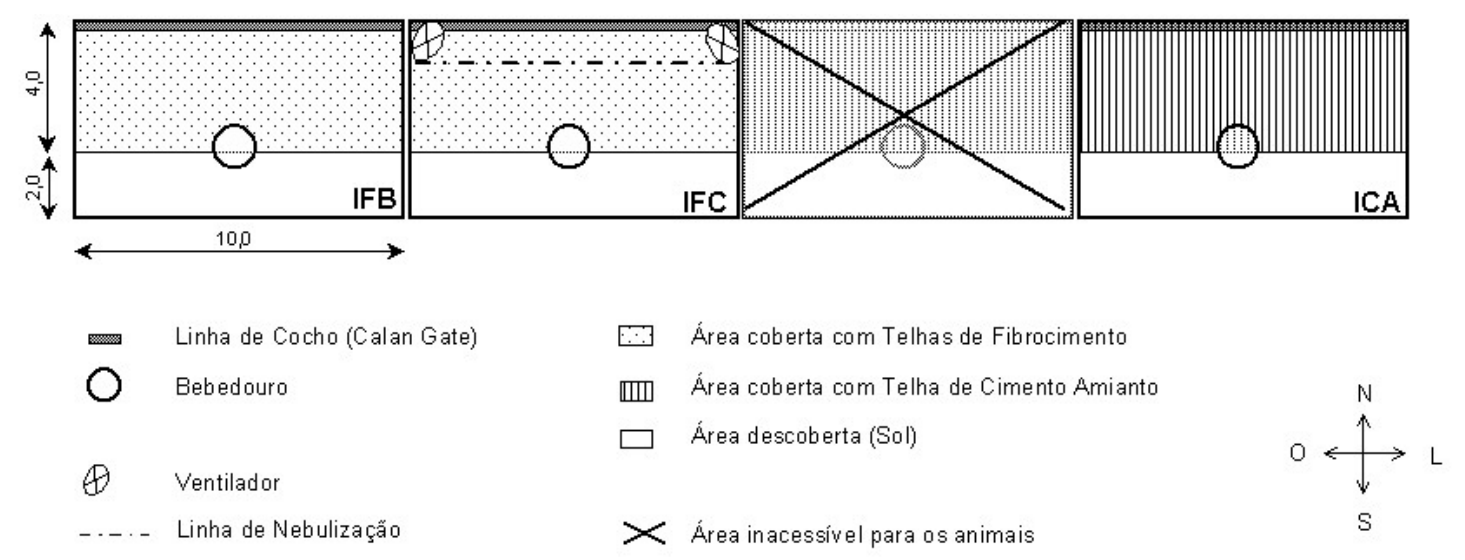

FIGURA 5. Representação esquemática das instalações estudadas

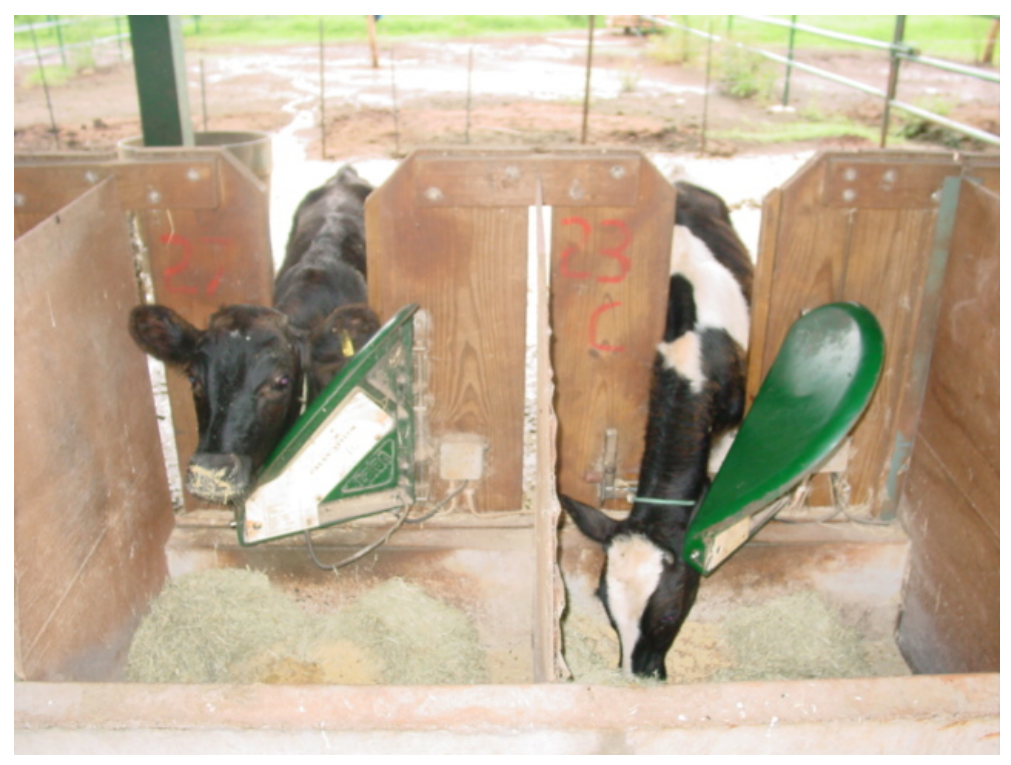

FIGURA 6. Animais utilizando o cocho de alimentação dotado do Sistema Calan Gate. 


\section{Instalação Cimento Amianto (ICA)}

Essa unidade contou com área coberta por telhas onduladas de cimento amianto com área coberta de $40 \mathrm{~m}^{2}$. Estas telhas possuíam as dimensões de 0,92 x 1,83 m, com $6 \mathrm{~mm}$ de espessura, com distância entre cavas (região mais baixa na onda de uma telha) de $0,18 \mathrm{~m}$ e distância entre cava e crista (região mais alta na onda de uma telha) de 0,05 m.

\section{Instalação Fibrocimento (IFB)}

Neste tratamento, foram instaladas telhas fabricadas durante $\mathrm{O}$ experimento, com matriz de cimento reforçada por fibras vegetais, e área coberta de $40 \mathrm{~m}^{2}$.

\section{Instalação Fibrocimento Climatizada (IFC)}

Para este tratamento foram também instaladas telhas com matriz de cimento reforçada por fibras vegetais e área coberta de $40 \mathrm{~m}^{2}$. Sob esta cobertura, instalaou-se dois ventiladores e um nebulizador de alta pressão (fog). Os ventiladores eram do tipo Clímax, da empresa Big Dutchman ${ }^{\circledR}$, com três pás, motor de $0,5 \mathrm{cv}(367,8 \mathrm{~W})$, diâmetro de $91,4 \mathrm{~cm}$, rotação de 1130 RPM e vazão de $5 \mathrm{~m}^{3} / \mathrm{s}$. O seu acionamento era realizado por meio de sensor de temperatura, instalado no centro da área coberta da instalação, à altura de 1,80 $\mathrm{m}$ do piso, para evitar que os animais tivessem acesso. Esse sensor era monitorado por painel de controle do tipo Climatec IV, da empresa Big Dutchman $^{\circledR}$. Os ventiladores foram instalados a $1,90 \mathrm{~m}$ do piso (medida a partir do centro do equipamento) e com inclinação, em relação à vertical, de $20^{\circ}$ para baixo. Esses ventiladores permaneciam ligados ininterruptamente sempre que a temperatura do ambiente excedia $24^{\circ} \mathrm{C}$. $\mathrm{O}$ equipamento de nebulização era composto de 13 bicos, eqüidistantes $0,80 \mathrm{~m}$ um do outro, com vazão de 3,3 l/h $\left(1,0 \times 10^{-6} \mathrm{~m}^{3} / \mathrm{s}\right)$ por bico, equipado com bomba da marca Kohlbach ${ }^{\circledR}$, modelo $56 \mathrm{H}-07 / 42$, de $1,5 \mathrm{cv}(1,1 \mathrm{~kW})$ e motor monofásico. O acionamento da nebulização também era feito com sensor de temperatura, instalado juntamente com o sensor que controlava os ventiladores, no centro da instalação. $O$ sistema de nebulização, propriamente dito, instalado na linha de cocho a 2,5 m do piso, era acionado a partir da temperatura do ar de $25^{\circ} \mathrm{C}$ e desligado 
sempre que a temperatura do ar se encontrava abaixo desse limite. A nebulização ainda possuía intermitência de operação, durante o seu funcionamento, permanecendo ligada durante $40 \mathrm{~s}$ e desligada por $20 \mathrm{~s}$.

A escolha para as temperaturas de acionamento da ventilação e da nebulização foi de acordo com BIANCA (1970); HAHN (1976) e SALEM et al. (1982), adaptados por SILVA (2000), que indicaram temperatura efetiva crítica superior de $25^{\circ} \mathrm{C}$. Portanto, os ventiladores eram ligados à temperatura de $24^{\circ} \mathrm{C}\left(1^{\circ} \mathrm{C}\right.$ abaixo da temperatura efetiva crítica superior) e a nebulização, para temperatura ambiente com valor igual à temperatura crítica superior $\left(25^{\circ} \mathrm{C}\right)$. Nas laterais da área coberta, a partir do telhado até a altura de 1,60 m do piso, foram instaladas lonas plásticas azuis para bloquear a incidência dos ventos externos, com o objetivo de conter o efeito da nebulização dentro do ambiente.

\subsubsection{Variáveis avaliadas}

\subsubsection{Variáveis climáticas}

Foram coletadas as temperaturas de bulbo seco, umidade relativa e temperatura de globo negro. Para a obtenção dos dados, empregou-se dataloggers da marca Onset $\mathrm{HOBO}^{\circledR}$, modelo $\mathrm{H} 8$, com sensores de temperatura e umidade internos e dois canais para sensores externos. Sendo que, para a coleta da temperatura de globo, foi implantado um sensor da marca Onset $\mathrm{HOBO}$, modelo TMC1-HA, com escala variando de $-40^{\circ} \mathrm{C}$ a $+100^{\circ} \mathrm{C}$, no centro geométrico de bóia plástica esférica de $22,3 \mathrm{~cm}$ de diâmetro externo, pintada com tinta preta fosca (NÄÄS \& ARCARO JÚNIOR, 2001).

Os dataloggers estavam devidamente instalados em três alturas diferentes, a saber: 1,80 m, 2,40 m e 3,00 m, em relação ao piso. Sendo que estes foram colocados no centro da área de cada instalação (Figura 7). 


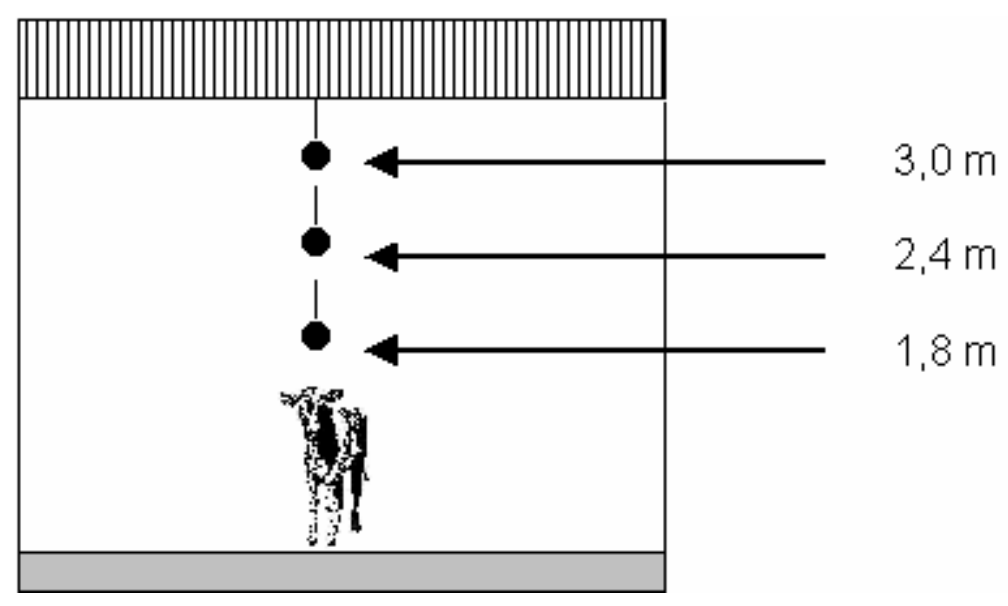

FIGURA 7. Esquema da disposição dos dataloggers instalados nas três alturas estudadas.

Para medir a velocidade do vento no ambiente externo (adjacente às instalações), foi utilizado um anemômetro totalizador da marca Hidrometria ${ }^{\circledR}$. A velocidade do vento, no interior das instalações (altura de 1,8 $\mathrm{m}$ em relação ao piso), foi mensurada com auxílio de anemômetro digital portátil da marca $1 O \mathrm{P}^{\circledR}$, com faixa de medição de 0,0 a $35,0 \mathrm{~m} / \mathrm{s}$.

O conforto térmico foi avaliado por meio do critério de dia crítico para bezerros. Entende-se por dia crítico aquele de entalpia elevada, a partir da qual começa a se acentuar o estresse térmico. Esse valor foi determinado como sendo $66,08 \mathrm{~kJ} / \mathrm{kg}$ ar de ar seco, obtido a partir da temperatura crítica superior de $25^{\circ} \mathrm{C}$ (SALEM et al., adaptado por SILVA, 2000) e da umidade relativa do ar de $75 \%$ (KELLY et al., 1984). A entalpia foi calculada por meio do programa computacional GRAPSI 4.0 (Universidade Federal de Viçosa), que considera a temperatura de bulbo seco $\left({ }^{\circ} \mathrm{C}\right)$, a umidade relativa (\%) e a pressão barométrica local, cujo valor adotado foi de $603,14 \mathrm{mmHg}$.

Posteriormente foram calculados os índices de ITU (Equação 5), ITGU (Equação 6) e CTR (Equação 7), determinados conforme descrito abaixo:

$$
I T U=T S+0,36 T o+41,2
$$

onde: Ts $=$ temperatura de bulbo seco $\left({ }^{\circ} \mathrm{C}\right)$;

To $=$ temperatura do ponto de orvalho $\left({ }^{\circ} \mathrm{C}\right)$. 


$$
\mathrm{ITGU}=\mathrm{Tg}+0,36 \mathrm{To}+41,5
$$

onde: $\mathrm{Tg}=$ temperatura de globo negro $\left({ }^{\circ} \mathrm{C}\right)$;

To $=$ temperatura do ponto de orvalho $\left({ }^{\circ} \mathrm{C}\right)$.

$$
\mathrm{CTR}=\delta(\mathrm{TMR})^{4}
$$

onde: $\mathrm{CTR}=$ carga térmica radiante $\left(\mathrm{Wm}^{-2}\right)$;

$\delta=5,67 \times 10^{-8} \mathrm{Wm}^{-2} \mathrm{~K}^{-4}$ (constante de Stefan-Boltzman);

$\mathrm{TMR}=$ temperatura média radiante.

$\mathrm{TMR}=100 \times\left[2,51 \times(\mathrm{Vv})^{0,5} \times(\mathrm{Tg}-\mathrm{Ta})+(\mathrm{Tg} / 100)^{4}\right]^{1 / 4}$

onde: $\mathrm{V} v=$ velocidade do vento $(\mathrm{m} / \mathrm{s})$

$\mathrm{Ta}=$ temperatura ambiente $(\mathrm{K})$

$\mathrm{Tg}=$ temperatura de globo negro $(\mathrm{K})$

Para caracterizar o ambiente na região do experimento, foi utilizada a estação meteorológica Campbell Scientific modelo $21 \mathrm{X}(\mathrm{L})$, existente junto ao Laboratório de Construções Rurais da FZEA, a cerca de $500 \mathrm{~m}$ do local do experimento, para a medida dos seguintes dados meteorológicos: temperatura ambiente, umidade relativa do ar, radiação global, precipitação e velocidade do vento. Para a análise estatística, empregou-se o delineamento inteiramente casualizado, pelo teste de Tukey $(p<0,01)$, no programa estatístico $S A S^{\circledR}$ (SAS, 1998).

\subsubsection{Variáveis fisiológicas}

As variáveis fisiológicas analisadas, relacionadas com o sistema termorregulador, foram temperatura retal (TR), temperatura de superfície da pele (TP) e freqüência respiratória ( $F R)$. A TR foi coletada diariamente, de todos os animais com o auxílio de termômetro clínico digital veterinário marca $\mathrm{BD}^{\circledR}$, modelo Accu-beep ${ }^{\mathrm{TM}}$ DIGITAL. Todas as medidas eram efetuadas às $6 \mathrm{e}$ às $14 \mathrm{~h}$, com o devido cuidado para se evitar o estresse dos animais. A coleta foi realizada na própria instalação, pela fácil contenção dos animais. Para a medida de TP foi utilizado termômetro de infravermelho da marca RAYTEK ${ }^{\circledR}$, modelo RAYST2PHC, na região do dorso, sempre nas manchas de coloração mais escuras de cada animal, à distância aproximada de $10 \mathrm{~cm}$. A freqüência 
respiratória foi tomada pela contagem dos movimentos respiratórios no flanco do animal, durante $15 \mathrm{~s}$, para depois ser calculada a FR por minuto. Para estas variáveis, fez-se a análise com delineamento em parcela sub-sub-dividida, com medidas repetidas duas vezes ao tempo, fazendo uso do procedimento GLM, do programa estatístico SAS ${ }^{\circledR}$ (SAS, 1998), com teste de Tukey $(p<0,05)$.

Em quatro dias, não consecutivos, típicos de estresse térmico (entalpia do ar as 12:00 acima de $66,08 \mathrm{~kJ} / \mathrm{kg}$ de ar seco), amostras de sangue da jugular foram coletadas de seis animais por tratamento (três mestiços e três holandeses), por meio de dois tubos para coleta de sangue da marca VACUETTE $^{\circledR}$. Um dos tubos era preparado sem anticoagulante e o outro com anticoagulante Heparina Sódica (Figura 8). As coletas foram feitas sempre nos mesmos animais, escolhidos aleatoriamente no primeiro dia de coleta. Após a coleta de sangue, a amostra no tubo com anticoagulante foi encaminhada ao Hospital Veterinário da Faculdade de Medicina Veterinária e Zootecnia (FMVZ) da USP, no Campus de Pirassununga, para mensuração do volume globular (hematócrito). As amostras nos tubos sem anticoagulante, permaneciam por um período de uma hora após a coleta, para a coagulação, e em seguida, encaminhadas ao Laboratório de Fisiologia Animal, Departamento de Ciências Básicas da Faculdade de Zootecnia e Engenharia de Alimentos (FZEA) da USP, Campus de Pirassununga. Essas amostras eram centrifugadas a 2200 RPM por $15 \mathrm{~min}$, à temperatura de $15^{\circ} \mathrm{C}$, para coleta do soro do sangue, a fim de se mensurarem os valores de creatinina e uréia. Para esta mensuração, empregou-se kits da marca LABORLAB ${ }^{\circledR}$. Na determinação dos valores de creatinina, foi utilizado o método cinético ou direto (BIGGS \& COOPER, $1961 \mathrm{e}$ MARTINEK, 1970). Na determinação dos valores de uréia, foi aplicado o método enzimático (HENRY, 1968 e HALLET \& COOK, 1971). Para a análise dos parâmetros sangüíneos, fez-se o uso do delineamento parcelas subdivididas (medidas repetidas no tempo), pelo teste de Tukey $(p<0,05)$, no programa estatístico SAS ${ }^{\circledR}$ (SAS, 1998). 


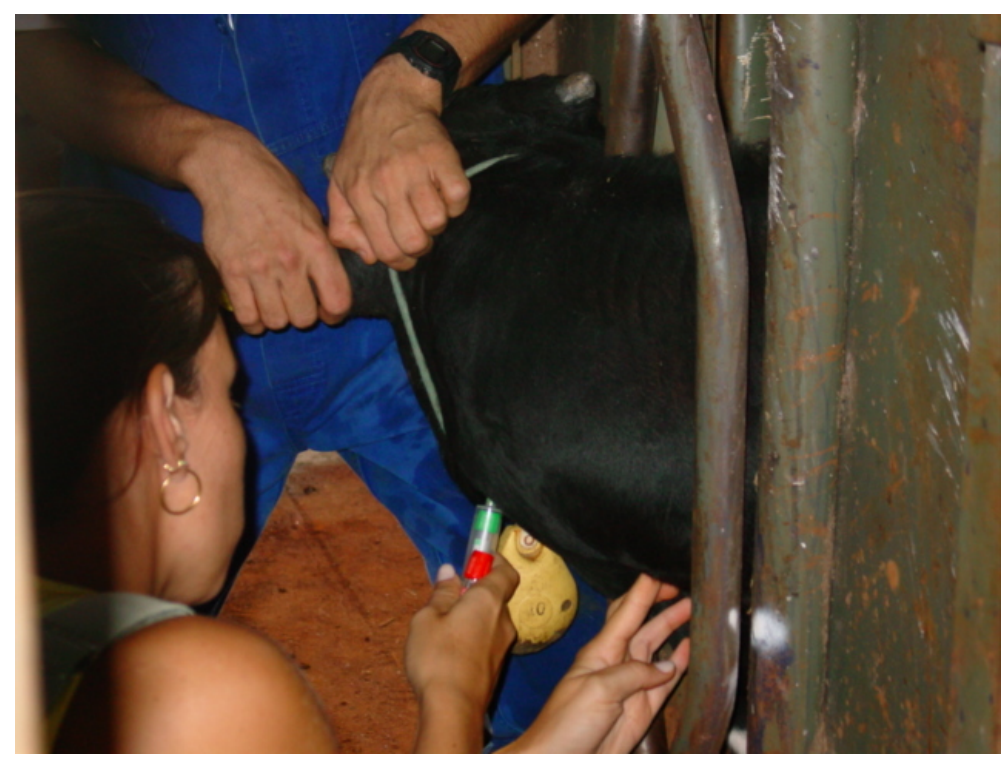

FIGURA 8. Coleta de sangue dos animais.

\subsubsection{Avaliação do Desempenho e Crescimento dos animais}

A cada 14 dias coletou-se peso vivo, altura e perímetro torácico para avaliação do desenvolvimento de todos os animais. Previamente a cada pesagem, os animais eram submetidos a um período de jejum de 12 horas. Antes da pesagem, com o animal já posicionado na balança, foi coletado, o perímetro torácico na região posterior do dianteiro, por meio de fita métrica (Figura 9). A balança utilizada era da marca FILIZOLA ${ }^{\circledR}$, com capacidade de $1500 \mathrm{~kg}$ e sensibilidade de $500 \mathrm{~g}$ (Figura 10). Ao saírem da balança, os animais eram contidos individualmente para mensuração da altura na cernelha, com o auxílio de um bastão marcado em centímetros. Os animais eram conduzidos sempre a um mesmo lugar, plano, para tomada das medidas. 


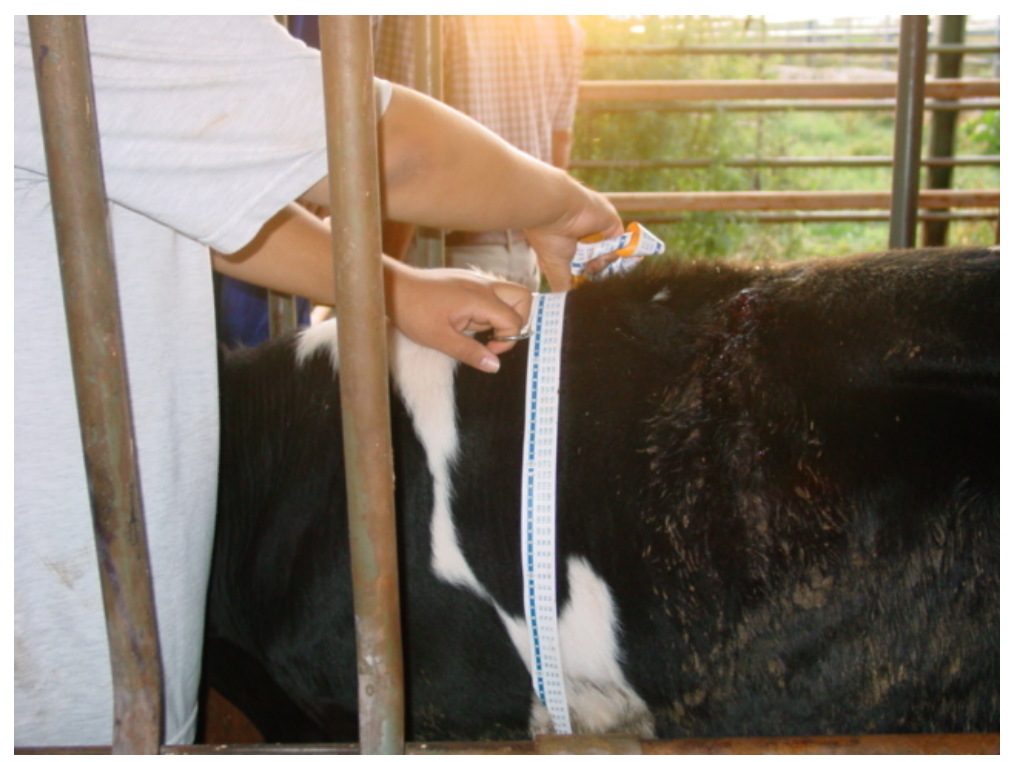

FIGURA 9. Coleta do perímetro torácico dos animais.

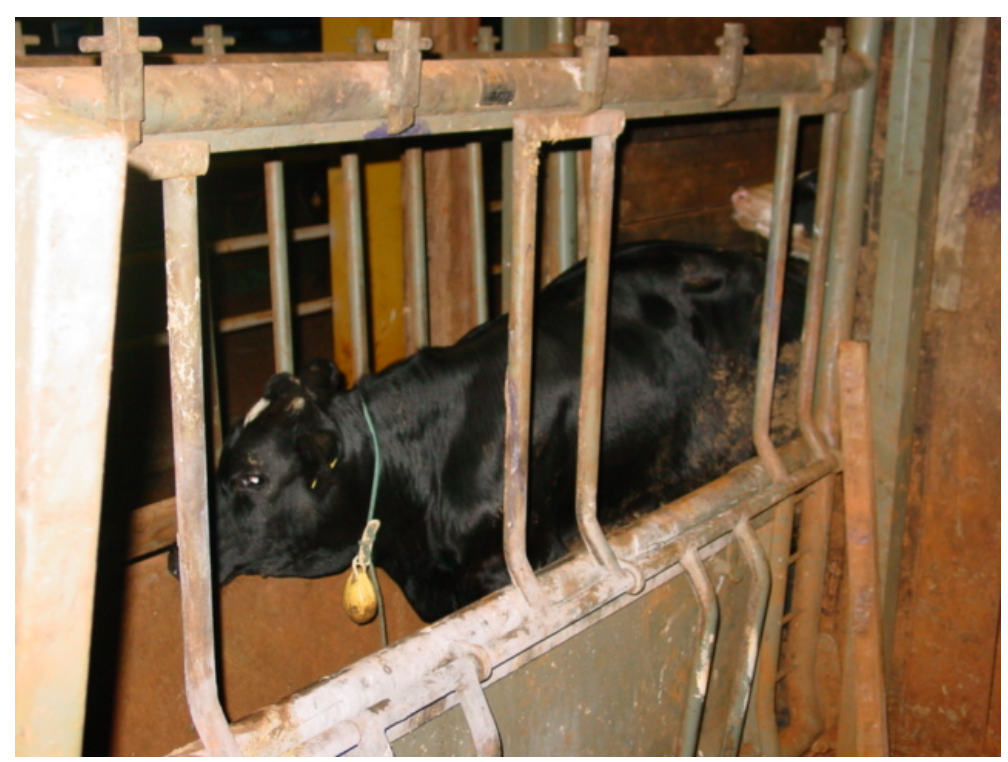

FIGURA 10. Pesagem dos animais.

Outra variável mensurada foi o consumo alimentar (ingestão de matéria seca, IMS), em que a ração era pesada diariamente no momento do fornecimento aos animais. A cada dois dias, eram retiradas e pesadas as sobras e, por diferença, calculava-se o consumo diário. Semanalmente se determinava a matéria seca (MS) da sobra.

Em conjunto com o valor de IMS e com o ganho de peso dos animais (GP), foram calculados os valores de conversão alimentar (CA). Os dados foram analisados por delineamento inteiramente casualizado, utilizando 0 
programa estatístico SAS ${ }^{\circledR}$ (SAS, 1998), com $5 \%$ de significância para o teste de Tukey.

\subsubsection{Comportamento}

Foi realizada a análise do comportamento ingestivo dos animais, durante duas séries de três dias consecutivos (típico de estresse térmico, com entalpia acima de $66,08 \mathrm{~kJ} / \mathrm{kg}$ de ar seco), durante 24 horas. O dia foi dividido em períodos: das 6 às $10 \mathrm{~h}$ (período 1), das 10 às $14 \mathrm{~h}$ (período 2), das 14 às $18 \mathrm{~h}$ (período 3) e das 18 às 6 h (período 4). Ao término de cada período, foi medido o consumo individual de cada animal, com a determinação do valor de consumo de matéria seca pela diferença de pesagem entre os períodos.

\subsubsection{Variáveis qualitativas e quantitativas da carcaca}

Aos 80 dias de experimentação, deixou-se os bezerros em jejum durante 12 horas, pesados e abatidos no Abatedouro Escola da Prefeitura do Campus Administrativo da USP em Pirassununga (PCAPS). Os animais foram sacrificados por sangria por meio de punção do músculo cardíaco, precedida de dessensibilização com pistola de dardo cativo. Logo após, se retirou cabeça, patas, testículos, couro e vísceras; a carcaça foi serrada ao meio e pesada, para obtenção do peso da carcaça quente (PCQ), seguida de sua lavagem. Após 1 hora do abate de cada animal foram determinados os parâmetros $\mathrm{pH}$ e temperatura no músculo Longissimus dorsi da meia carcaça esquerda, na altura da $12^{\mathrm{a}}$ costela, usando-se pHmetro e termômetro digital, com sondas de penetração (modelo HI8314, marca Hanna Instruments). O rendimento da carcaça $(R C)$ foi expresso pela porcentagem de PCQ em relação ao PV (Figura 11). 

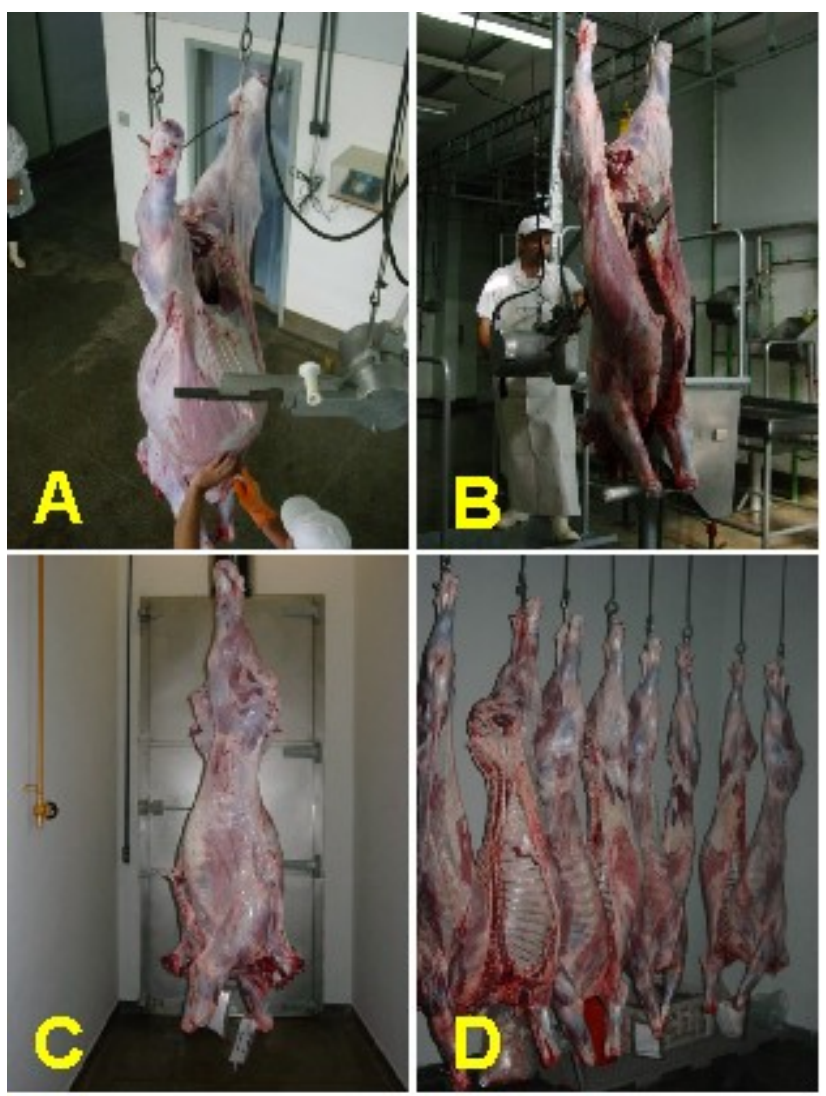

FIGURA 11. Processo de abate dos animais. A Evisceração; B - Divisão da carcaça; C - Pesagem e identificação das carcaças; D - Armazenagem em câmara fria.

Na seqüência conduziu-se, as duas meias carcaças de cada animal a uma câmara fria a $0^{\circ} \mathrm{C}$ por 24 horas. Porém, por problemas técnicos do abatedouro, estas carcaças somente foram expostas ao resfriamento após 24 horas, por um período de apenas 6 horas, a $0^{\circ} \mathrm{C}$. No intuito de evitar possíveis queimaduras por frio (Figura 12) envolveu-se as carcaças em filme plástico. 


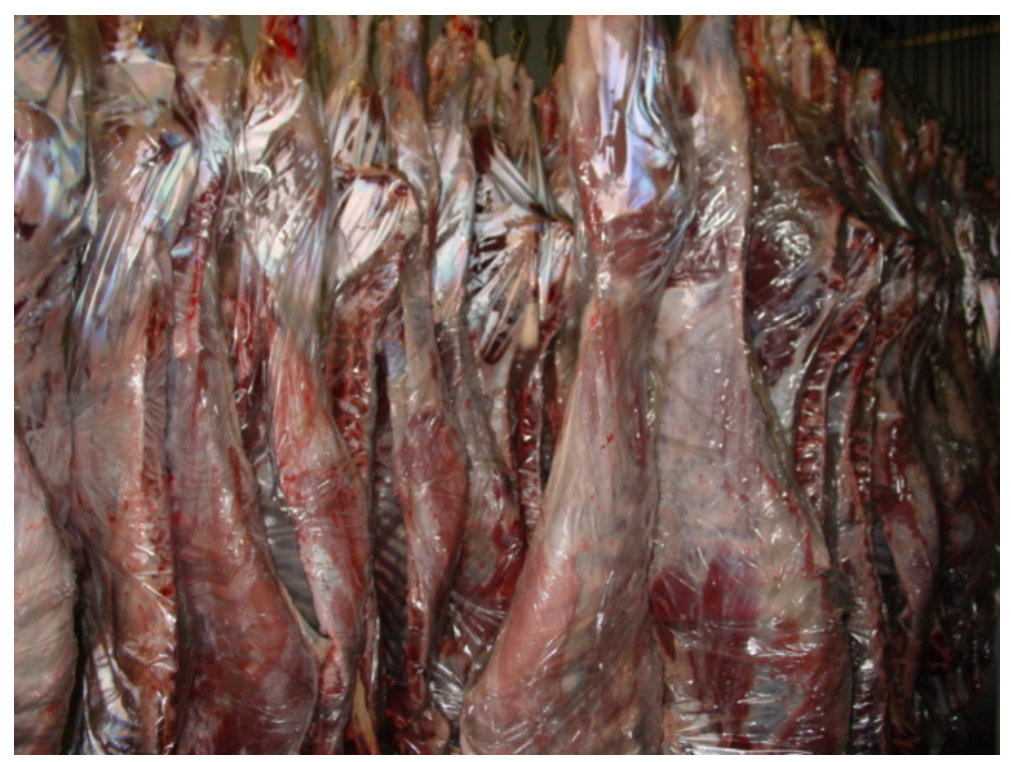

FIGURA 12. Carcaças protegidas com filme plástico.

Após 30 horas do abate, coletou-se novamente o pH e a temperatura da meia carcaça esquerda pelo procedimento descrito anteriormente. Em seguida, todas as meias carcaças esquerdas dos 18 animais submetido à coleta de sangue, divididas em dianteiro, ponta de agulha e traseiro. Em continuação, foi feita a desossa e a pesagem da porção comestível e de osso.

Após a desossa dessas 18 meias carcaças esquerdas, foi realizada a desossa de todas as outras meias carcaças, esquerdas e direitas, para cálculo da produção total de carne.

Foi avaliada a área de olho de lombo, por meio da contagem em $\mathrm{cm}^{2}$ pelo método do plástico quadriculado (Figura 13). As mensurações de espessura de gordura foram realizadas com a utilização de paquímetro, sendo a medida tomada na terça parte da porção superior proximal da curvatura do músculo Longissimus dorsi.

A análise da coloração foi feita em amostras do músculo Longissimus dorsi com o auxílio de um colorímetro portátil (modelo MiniScan XE, marca Hunter Lab), com fonte de luz D65, ângulo de observação de $10^{\circ}$ (em relação à normal do plano de medição) e abertura da célula de medida de $30 \mathrm{~mm}$. Utilizaram-se as escalas $L^{*}$, $a^{*}$ e $b^{*}$ do sistema CIELab, onde $L^{*}$ é o croma associado à luminosidade ( $\mathrm{L}^{*}=0$ preto, 100 branco), $\mathrm{a}^{*}$ é o croma que varia do verde (-) ao vermelho (+); e $b^{*}$, que varia do azul (-) ao amarelo (+). As amostras foram deixadas em repouso, com a superfície exposta ao ambiente, 
por 30 min, para oxigenação da mioglobina (ABULARACH et al., 1998). As medidas, então, realizadas em três posições diferentes, na superfície de interesse, para cálculo de um valor médio (Figura 14).

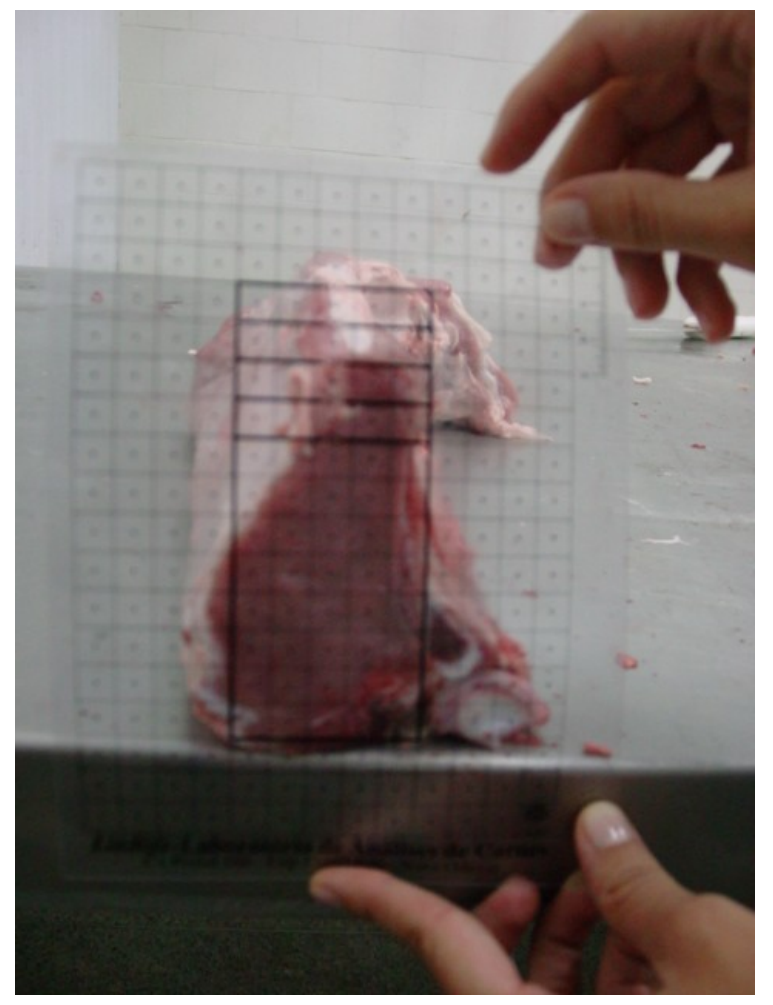

FIGURA 13. Mensuração da área de olho de lombo (AOL), pelo método do plástico quadriculado.

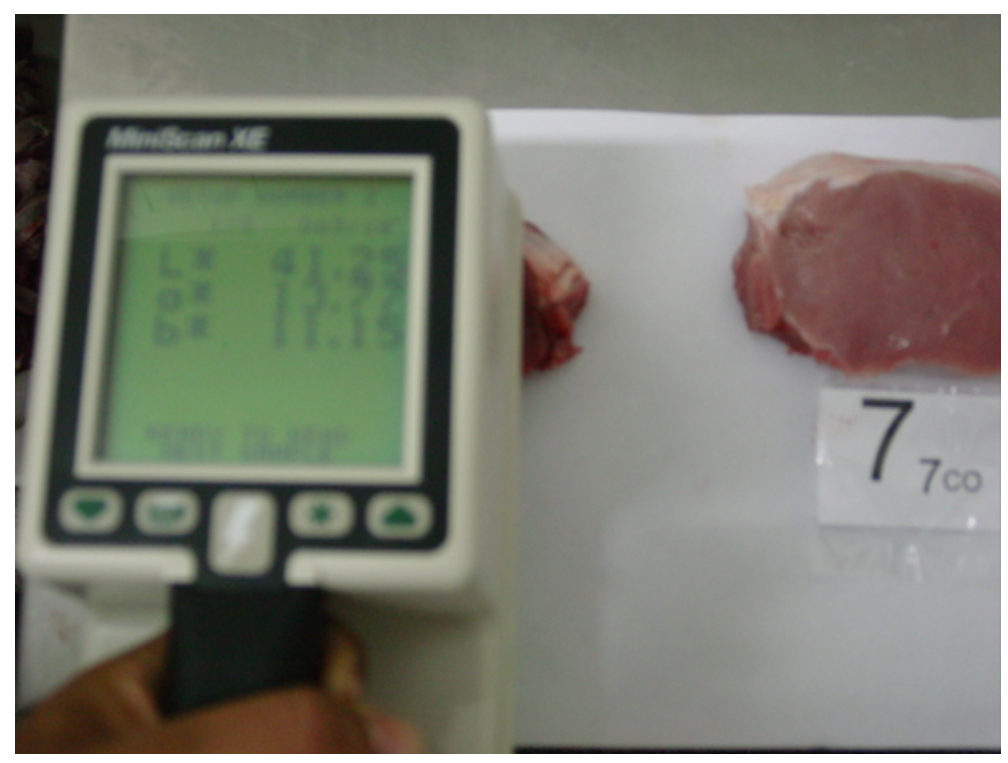

FIGURA 14. Avaliação da cor apresentada pela carne de vitelo. 
Após a avaliação da coloração das carnes, as amostras foram embaladas a vácuo e seguiram para câmara fria a $8^{\circ} \mathrm{C}$ durante 7 dias (período de maturação). Ao final desse período, as amostras submeteram-se à análise da textura objetiva com o aparelho Warner-Bratzler, de acordo com os procedimentos propostos por WHEELER et al. (1995) .

Para análise das variáveis relacionadas com carcaça, foi utilizado o delineamento inteiramente casualizado, pelo teste de Tukey $(p<0,05)$ com o programa estatístico SAS ${ }^{\circledR}$ (SAS, 1998).

\subsubsection{Indicativo Econômico}

$\mathrm{Na}$ implantação dos três tipos de tratamentos, levantou-se dados dos investimentos com instalações. Além disso, ainda foi levantado o custo por grupamento genético, dentro das diferentes instalações.

A metodologia para estabelecimento do custo de produção de vitelo foi a do custo total de produção, que envolve custos fixos e variáveis, conforme descrita por SAVASTANO JR. et al. (1995). No item custo fixo, considerou-se a depreciação calculada pelo método linear. Com relação aos custos variáveis, foram considerados os gastos com materiais de consumo, mão-de-obra, reparos e manutenção de equipamentos e instalações, com base em trabalho apresentado por PINHEIRO et al. (2003).

Para a determinação dos custos relativos a mão-de-obra, considerou-se a sua utilização para manejo dos animais. O custo hora da mão-de-obra determinado a partir do salário médio da região de Pirassununga, no período de dezembro de 2002 a março de 2003 para as diferentes funções.

No item instalações, fez-se uma extrapolação para atingir a lotação ideal de seis animais por grupamento genético, por instalação. Isso foi necessário porque a instalação estava subutilizada, isto é, poderia comportar mais animais do que o número de fato empregado.

Quanto à alimentação, adotou-se dieta balanceada com alta proporção concentrado:volumoso. Foram empregados os preços comerciais dos ingredientes vendidos na região de Pirassununga, para o período do experimento. 
O cálculo do valor dos animais, foi considerado pelo preço médio para bezerros com 90 dias de idade, na região de Pirassununga entre os meses de outubro e novembro de 2002.

Todos os valores monetários referem-se ao período de 17 de dezembro de 2002 a 17 de março de 2003, sendo que a taxa média de câmbio do dólar norte-americano (comercial para compra), neste período, foi de $\mathrm{R} \$ 3,51$.

Foi calculada a produção de carne por tipo de instalação e por grupamento genético, a fim de se obter o custo de produção por quilo de carne de vitelo $(R \$ / \mathrm{kg})$. 


\section{Resultados}

\subsection{Telha de Fibrocimento}

Antes da moldagem das telhas, foram feitos os testes com a massa recém-produzida, para determinação do índice de consistência, sendo que o valor aceitável varia de 220 a $250 \mathrm{~mm}$ (DEVITO, 2003). Os resultados de todas as séries seguem na Tabela 7. Não foi realizada análise estatística para estes valores, por serem utilizados apenas na definição do grau de facilidade de moldagem (trabalhabilidade) da massa recém-fabricada.

\begin{tabular}{cc} 
TABELA 7. & $\begin{array}{l}\text { Índice de consistência } \\
\text { encontrado para as } \\
\text { diferentes séries. }\end{array}$ \\
\hline Séries & $\begin{array}{c}\text { Índice de } \\
\text { Consistência (mm) }\end{array}$ \\
\hline E & 220 \\
ES & 223 \\
S & 228 \\
\hline
\end{tabular}

Todas as telhas apresentaram espessura média \pm erro-padrão de 9,0 \pm $0,7 \mathrm{~cm}$, sem diferença significativa $(p<0,01)$ entre as séries.

\subsubsection{Caracterização Física}

Absorção de água, massa específica e volume aparente de vazios estão apresentados nas Figuras 15 a 17 . Os melhores resultados para massa específica (Figura 15), aos 28 dias de idade, obtidos pelas séries ES e S, com valores de 1,35 e $1,36 \mathrm{~g} / \mathrm{cm}^{3}$, respectivamente. Tais valores foram maiores $(p<0,01)$ que o resultado apresentado pela série $E$, com valor igual a 1,17 $\mathrm{g} / \mathrm{cm}^{3}$. Para a avaliação aos 155 dias de idade, os resultados de massa específica apresentaram o mesmo comportamento. Os valores de massa específica para os tratamentos ES e $S\left(1,43\right.$ e $1,39 \mathrm{~g} / \mathrm{cm}^{3}$, respectivamente) 
não diferiram entre si e apresentaram desempenho superior $(p<0,01)$ ao da massa específica apresentada pela série $E\left(1,33 \mathrm{~g} / \mathrm{cm}^{3}\right)$. Apenas a série $E$ mostrou aumento significativo para a massa específica com a idade, que pode ser parcialmente explicado pela carbonatação da matriz cimentícia. A alta porosidade deste compósito parece facilitar a rápida carbonatação da cal livre presente nos produtos de hidratação (TAYLOR, 1997).

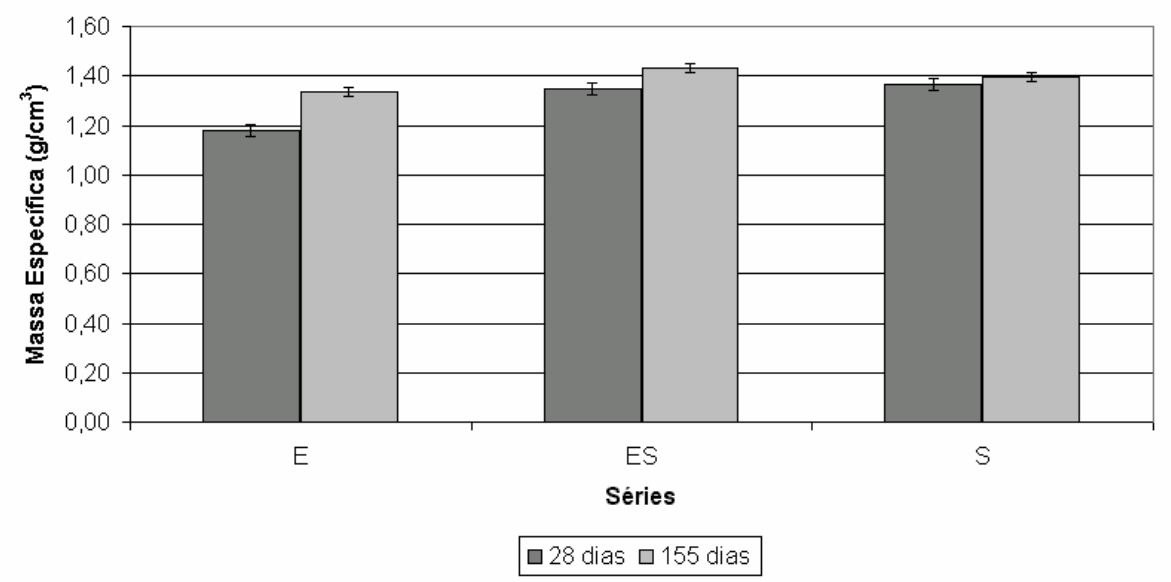

FIGURA 15. Resultados da massa específica aparente $\left(\mathrm{g} / \mathrm{cm}^{3}\right)$ e erropadrão das médias.

A Figura 16 mostra, aos 28 dias de idade, o maior $(p<0,01)$ valor de volume aparente de vazios registrado para a série $E(50,3 \%)$, que foi diferente significativamente $(p<0,01)$ das séries ES $(44,0 \%)$ e $S(42,3 \%)$, as quais não diferiram entre si.

Para a idade de 155 dias, a série $E$ manteve-se com o desempenho menos favorável $(49,5 \%)$, porém, sem diferença significativa para a série ES $(47,7 \%)$. O volume aparente de vazios para a série $S$ foi igual a $44,8 \%$, não diferindo apenas da série ES. O efeito do envelhecimento não foi significante para nenhuma das séries, embora tenha-se observado uma tendência de aumento no volume aparente de vazios para as séries ES e $S$, fato este, que pode ser explicado pela alta degradação da fibra de sisal, conforme apresentado por GRAM (1988). 


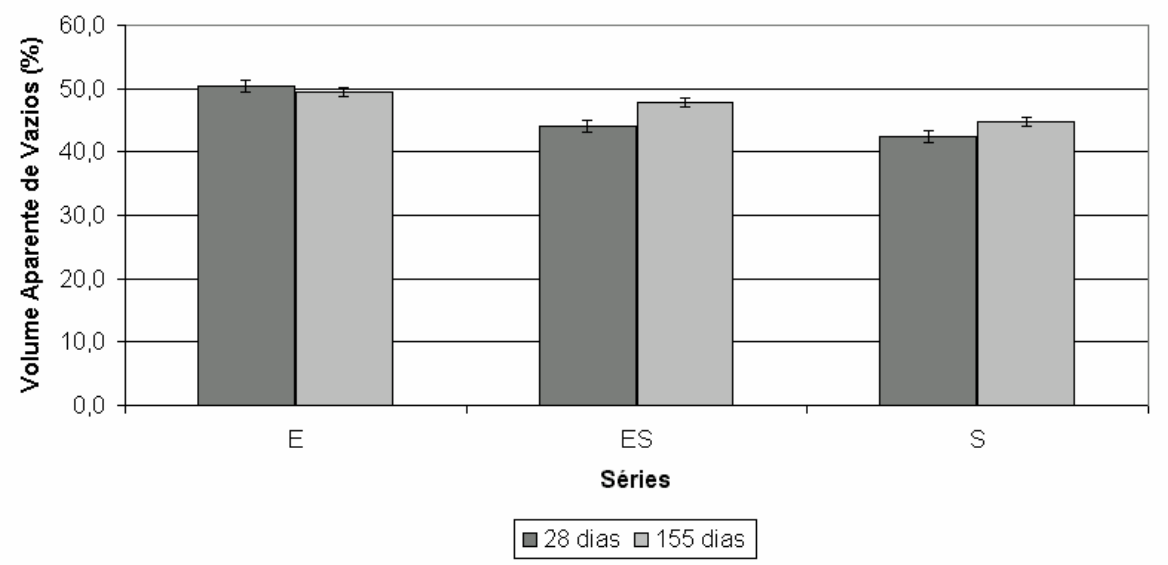

FIGURA 16. Resultados do volume aparente de vazios (\%) e erro-padrão das médias.

Os melhores resultados de absorção de água (AA) aos 28 dias de idade estão relacionados com as séries ES e $S(32,1$ e $31,0 \%$ em massa, respectivamente) que não diferiram entre si (Figura 17). Para a série E, a absorção de água atingiu $42,7 \%$, resultado considerado maior $(p<0,01)$ que os demais. Este fato pode ser entendido pela alta proporção de fibra na série $\mathrm{E}$ ( $5 \%$ em massa) em comparação as outras ( $3 \%$ em massa). Adicionalmente, é esperado um maior número de filamentos de fibra de eucalipto, por causa do baixo comprimento médio desta fibra (Tabela 3), fato esse que, aliado à hidrofilicidade da fibra celulósica, contribuiu para a alta absorção da série $E$.

Após 155 dias de idade, a série $E$ apresentou o valor de $37,1 \%$ de absorção de água, sendo considerado ligeiramente acima do limite de $37 \% \mathrm{em}$ massa, conforme recomendado pela ABNT (NBR-7581). Esta série apresentouse com pior desempenho em relação às séries $\operatorname{ES~}(33,4 \%)$ e $S(32,1 \%)$, que não diferiram entre si. $O$ envelhecimento não influenciou a absorção de água para as séries ES e $\mathrm{S}$, que mantiveram valores similares para as duas idades avaliadas (28 e 155 dias). 


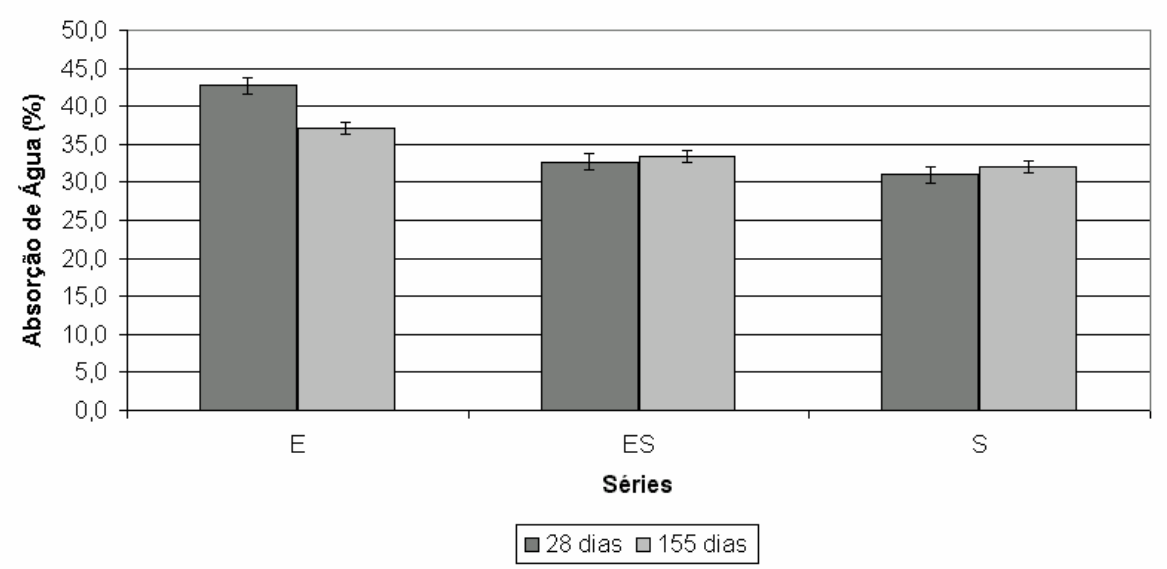

FIGURA 17. Resultado de absorção de água (\%) e erro-padrão das médias.

\subsubsection{Caracterização Mecânica}

Aos 28 dias de idade, os resultados de força na ruptura foram de $533 \mathrm{~N}$ para a série $\mathrm{E}, 761 \mathrm{~N}$ para ES e $1111 \mathrm{~N}$ para a série $\mathrm{S}$ (Figura 18). As espessuras das telhas devidamente coletadas na seção da ruptura depois dos testes mecânicos (três determinações com paquímetro). A média dos valores para as series foram: $8 \mathrm{~mm}$ para as telhas da série $E, 9 \mathrm{~mm}$ para a série ES e $10 \mathrm{~mm}$ para a série $S$. $O$ melhor resultado $(p<0,01)$ foi obtido pela série com $3 \%$ em massa de fibra de sisal (S). Os resultados indicam a melhor capacidade de reforço com fibras de sisal em razão da alta relação de aspecto (Tabela 3), como previamente discutido por COUTTS (1988). Todos os resultados estão presentes dentro dos limites aceitáveis de força na ruptura, conforme descritos por GRAM \& GUT (1994). Os limites aceitáveis relacionados com a espessura da telha, são apresentados com os seguintes valores: $425 \mathrm{~N}(8 \mathrm{~mm}), 553 \mathrm{~N}(9$ $\mathrm{mm})$ e $680 \mathrm{~N}(10 \mathrm{~mm})$.

Aos 155 dias de idade, as séries mostraram os seguintes resultados: $297 \mathrm{~N}$ para a série E, $348 \mathrm{~N}$ para a série ES e $640 \mathrm{~N}$ para a S, sendo que todas as séries se apresentaram abaixo do limite proposto por GRAM \& GUT (1994). O melhor resultado $(p<0,01)$ foi novamente relacionado com a série $S$.

Todas as séries mostraram redução drástica $(p<0,01)$ de até $55 \%$ no valor de força na ruptura, para a avaliação aos 155 dias de idade. Mesmo com a substituição do cimento amianto por escória e adição pozolânica na formulação da matriz cimentícia, a degradação das fibras vegetais foi rápida, 
devido ao ambiente alcalino combinado com clima quente e úmido. TOLÊDO FILHO et al. (2000), ao usar processo similar para a produção de fibrocimento, encontraram degradação considerável das fibras de sisal como reforços da matriz cimentícia, com $40 \%$ em massa de escória de alto forno como substituto do cimento amianto.

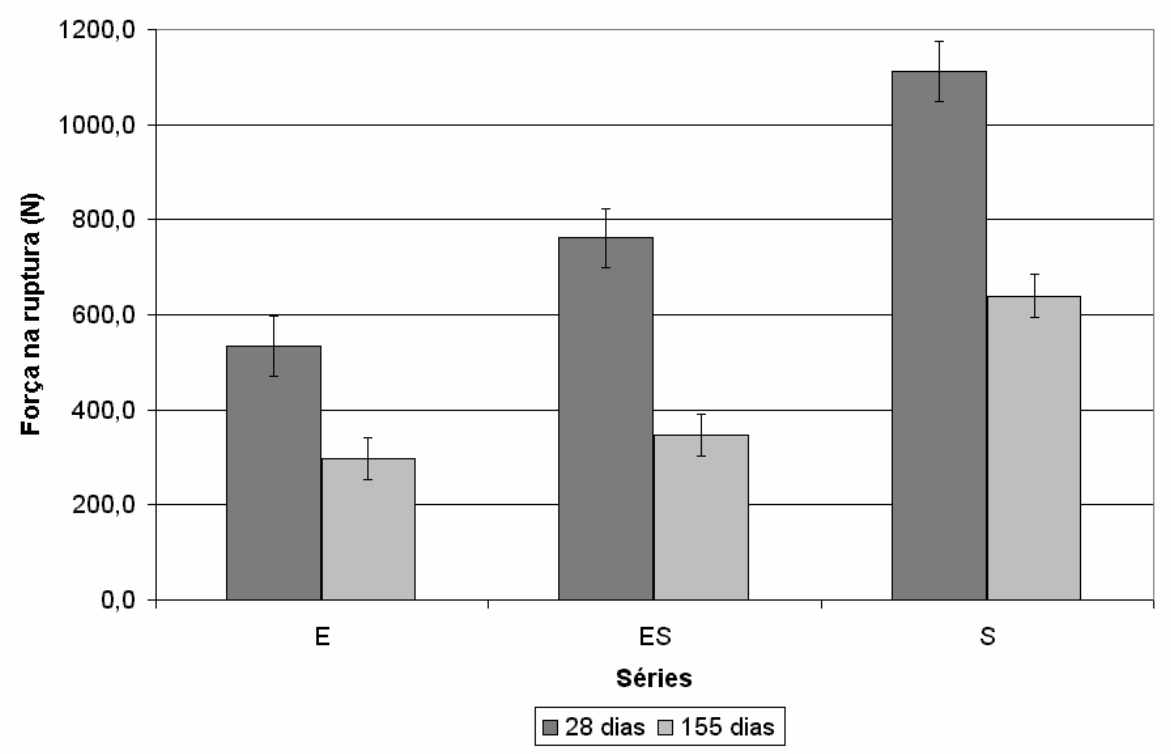

FIGURA 18. Valores de força na ruptura (N) e erro-padrão das médias.

Os resultados de Energia Específica $\left(\mathrm{J} / \mathrm{m}^{2}\right)$, demonstrados na Figura 19, seguiram o mesmo comportamento que os resultados de força na ruptura. $A$ série com reforço somente de fibra de sisal (S) apresentou melhor desempenho $(p<0,01)$ para as idades de 28 e 155 dias (1152 e $612 \mathrm{~J} / \mathrm{m}^{2}$, respectivamente), comparado com a série ES (464 e $316 \mathrm{~J} / \mathrm{m}^{2}$ aos 28 e 155 dias) e a série $E$ (453 e $243 \mathrm{~J} / \mathrm{m}^{2}$ aos 28 e 155 dias). Para o período de envelhecimento, somente a série $S$ apresentou redução significativa $(p<0,01)$ de Energia Específica. TOLÊDO FILHO et al. (2000) e BENTUR \& AKERS (1989), notaram redução similar da tenacidade em compósitos de cimento Portland reforçados com fibras vegetais. Esses autores atribuíram esse fato à mineralização da fibra, pela migração dos produtos hidratados para os poros existentes na fibra. A decomposição das fibras em ambiente alcalino e microfissuração da matriz são 
mecanismos de degradação igualmente importantes (GRAM, 1988 e SAVASTANO JÚNIOR et al., 2001).

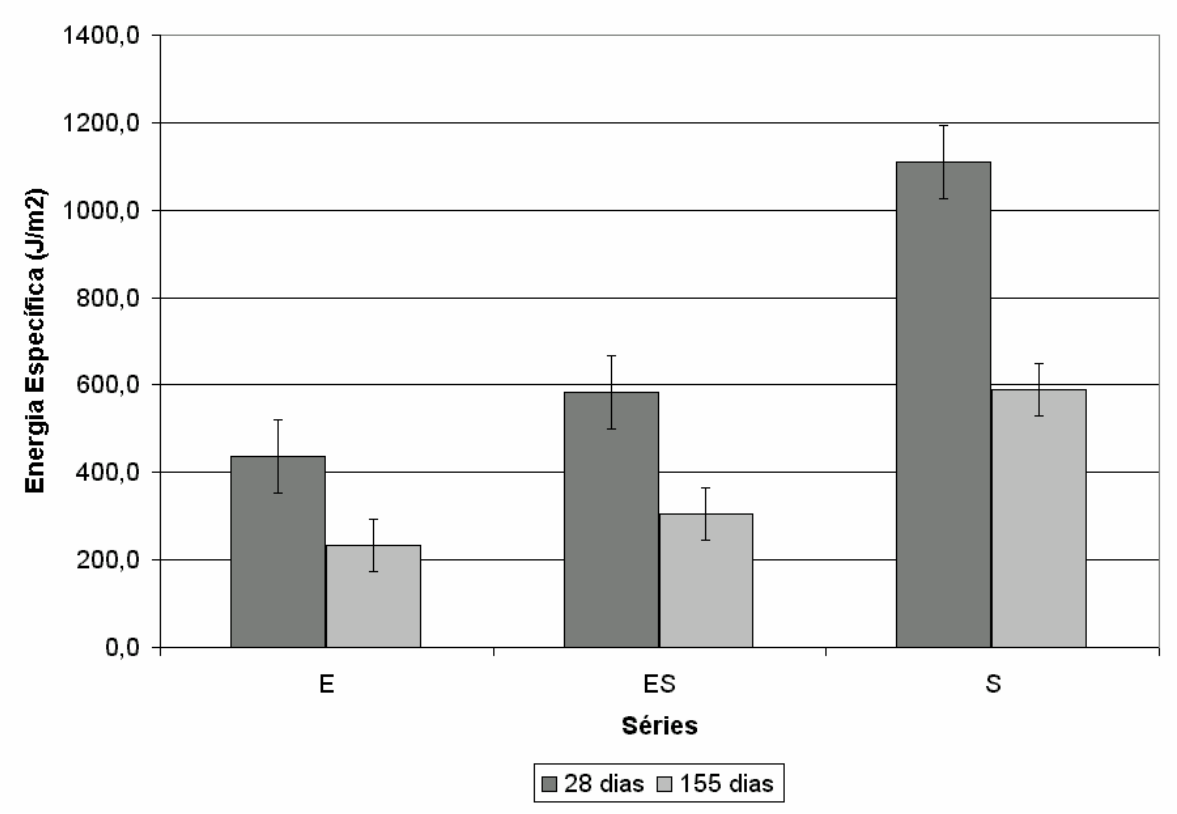

FIGURA 19. Valores de energia específica $\left(\mathrm{J} / \mathrm{m}^{2}\right)$ e erro-padrão das médias.

\subsubsection{Desempenho Térmico}

Para a análise do desempenho térmico, através da temperatura da superfície inferior da telha, dividiu-se o dia em dois períodos: o primeiro entre as 17 e 7 h e o segundo das 8 às 16 h (Figura 20). Para o primeiro período, ambas as telhas tiveram comportamento térmico semelhante, sem diferença significativa entre as temperaturas da superfície inferior das telhas. Já no segundo período (horas mais quentes do dia), observou-se diferença $(p<0,01)$ nas temperaturas de superfície entre os tipos de cobertura. A telha de cimento celulose apresentou-se com temperatura menor $(p<0,01)$ do que a de cimento amianto. Às $12 \mathrm{~h}$, observou-se diferença média de $11,5^{\circ} \mathrm{C}$, entre as temperaturas da superfície inferior das duas telhas. Cabe ressaltar que, segundo TOLEDO (1970), citado por SILVA et al. (1990), as temperaturas elevadas na face inferior das telhas podem vir a ser a causa principal do desconforto térmico, no interior das instalações. 


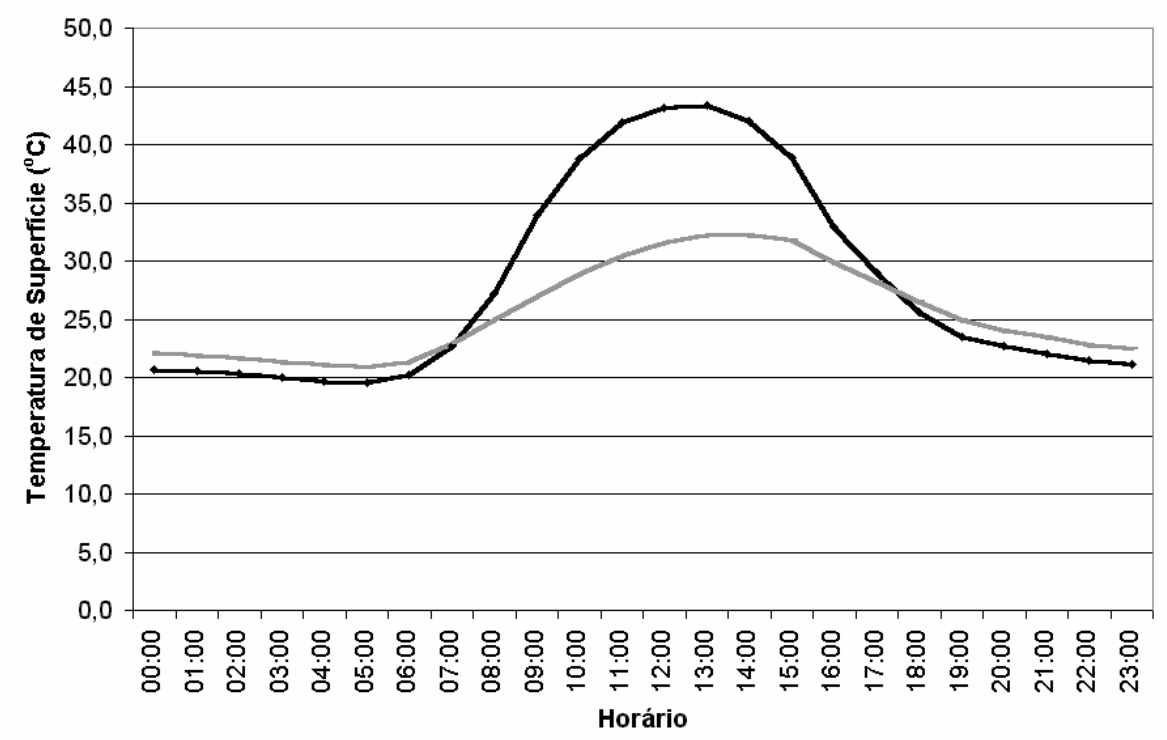

$\rightarrow$ Cimento Amianto - Cimento Celulose

FIGURA 20. Avaliação das médias da temperatura de superfície das telhas estudadas ao longo de 24 horas.

\subsection{Produção de Vitelos}

\subsubsection{Análise Física do Ambiente}

São apresentados, na Tabela 8 , os valores de temperatura ambiente (máxima e mínima), umidade relativa do ar e pluviosidade acumulada do período, do ambiente externo às instalações.

TABELA 8. Dados meteorológicos do ambiente externo das instalações referentes ao período experimental.

\begin{tabular}{|c|c|c|c|c|c|}
\hline & \multicolumn{4}{|c|}{ Período } & \multirow[b]{2}{*}{ Média } \\
\hline & dez/02 & $\mathrm{jan} / 03$ & fev/03 & mar/03 & \\
\hline & $15-31$ & $01-31$ & $01-28$ & $01-17$ & 92 dias \\
\hline Temperatura Máxima $\left({ }^{\circ} \mathrm{C}\right)$ & 30,7 & 29,5 & 32,0 & 30,1 & 30,6 \\
\hline Temperatura Mínima $\left({ }^{\circ} \mathrm{C}\right)$ & 20,4 & 19,9 & 19,6 & 19,2 & 19,8 \\
\hline Umidade Relativa Média (\%) & 84,7 & 90,8 & 83,3 & 88,3 & 86,8 \\
\hline Chuvas (mm no período) & 55,2 & 266,2 & 111,3 & 130,7 & $563,4^{*}$ \\
\hline
\end{tabular}

* chuva acumulada no período

Foi realizada a análise estatística $(p<0,01)$ para o estudo das variáveis físicas do ambiente interno, para os seguintes horários 8, 11, 14 e $17 \mathrm{~h}$. Nas Figuras 21 a 28, são apresentados os resultados para temperatura ambiente, umidade relativa, temperatura de globo, índice de temperatura e umidade, 
índice de temperatura de globo e umidade, carga térmica radiante, entalpia e velocidade do vento.

Para todas as variáveis analisadas, com exceção da velocidade do vento, foi encontrado o efeito da hora, apresentando sempre valores diferentes significativamente maiores para os horários das 11 e das $14 \mathrm{~h}$, em relação as horários das 8 e das $17 \mathrm{~h}$.

Em relação a temperatura ambiente, foi observada diferença significativa entre os tratamentos sem climatização, ICA $\left(29,3^{\circ} \mathrm{C}\right)$ e IFB $\left(28,8^{\circ} \mathrm{C}\right)$, para o tratamento climatizado, IFC $\left(28,0^{\circ} \mathrm{C}\right)$, mostrando uma melhoria do ambiente físico de instalação aberta através do uso do sistema de resfriamento, conforme explícito na Figura 21. Esses resultados estão de acordo com trabalhos relacionados ao uso de sistema de climatização composto por nebulização e ventilação. MARTELLO (2002) apresentou redução de $4,5^{\circ} \mathrm{C}$, enquanto ROMA JÚNIOR et al. (2001) relataram redução de $1,5^{\circ} \mathrm{C}$ para ambientes climatizados.

No entanto, para todos os tratamentos, a temperatura ambiente permaneceu acima daquela indicada para bezerros em crescimento, que é de $27^{\circ} \mathrm{C}$, de acordo com BIANCA (1970); HAHN (1976) e SALEM et al. (1982), adaptados por SILVA (2000).

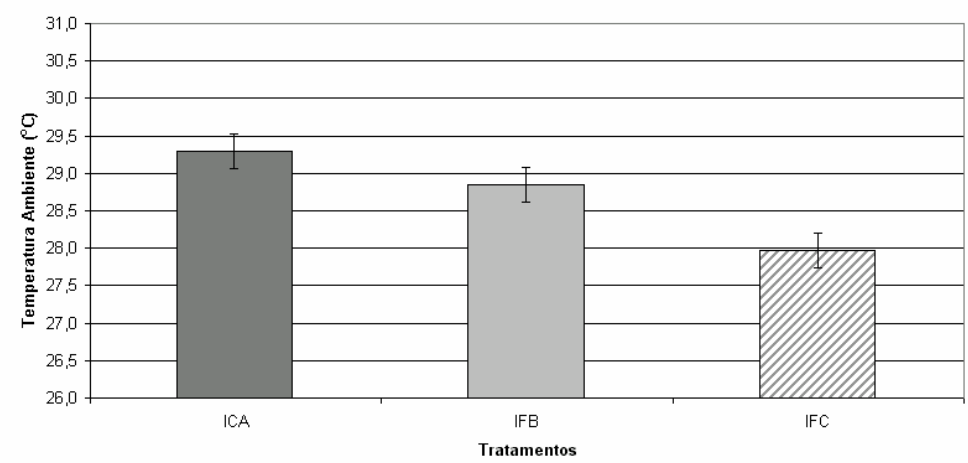

FIGURA 21. Médias da temperatura ambiente $\left({ }^{\circ} \mathrm{C}\right)$ e erropadrão da média dos diferentes tratamentos.

O tratamento com menor valor de umidade relativa (Figura 22) foi o IFB $(61,8 \%)$, não diferindo do tratamento ICA $(65,0 \%)$, porém com diferença significativa $(p<0,01)$ em relação ao tratamento IFC $(67,7 \%)$. Os tratamentos ICA e IFC também não diferiram entre si. 
Em trabalho realizado por ROMA JÚNIOR et al. (2001), o uso de sistema de climatização composto por nebulização associada com ventilação, não alterou significativamente a umidade relativa. Tal fato não é coincidente com o resultado do presente trabalho, em que a climatização aumentou a umidade relativa na instalação climatizada (IFC), apresentando sempre o maior valor entre os três tratamentos. Mesmo assim, todos os tratamentos permaneceram dentro dos limites aceitáveis de umidade relativa para bezerros, que é de até $75 \%$ (KELLY et al., 1984).

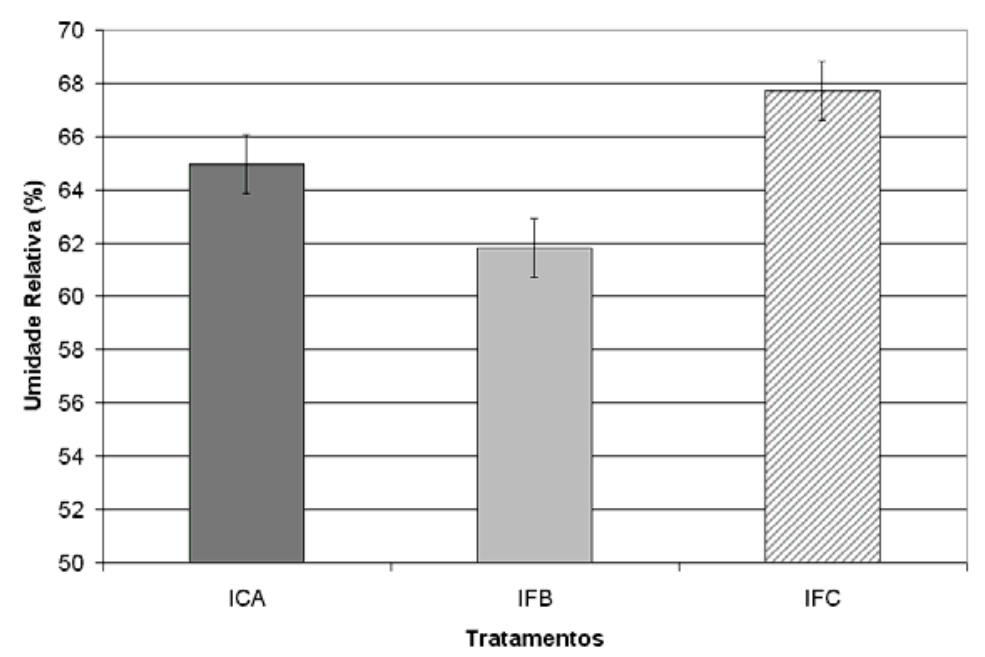

FIGURA 22. Médias de umidade relativa (\%) e erro-padrão da média dos diferentes tratamentos.

Para a temperatura de globo negro (Figura 23), o tratamento IFC $\left(28,5^{\circ} \mathrm{C}\right)$ apresentou valor inferior $(p<0,01)$ do que os tratamentos IFB $\left(29,6^{\circ} \mathrm{C}\right)$ e ICA $\left(29,9^{\circ} \mathrm{C}\right)$. Sendo que os tratamento IFB e ICA não diferiram entre si.

Com isso, a temperatura de globo negro teve comportamento semelhante ao da temperatura ambiente, apresentando somente diferença para o uso da climatização no ambiente. Essa tendência está de acordo com ROMA JÚNIOR et al (2001), que apresentaram resultados de redução da temperatura de globo negro em função do uso da climatização. 


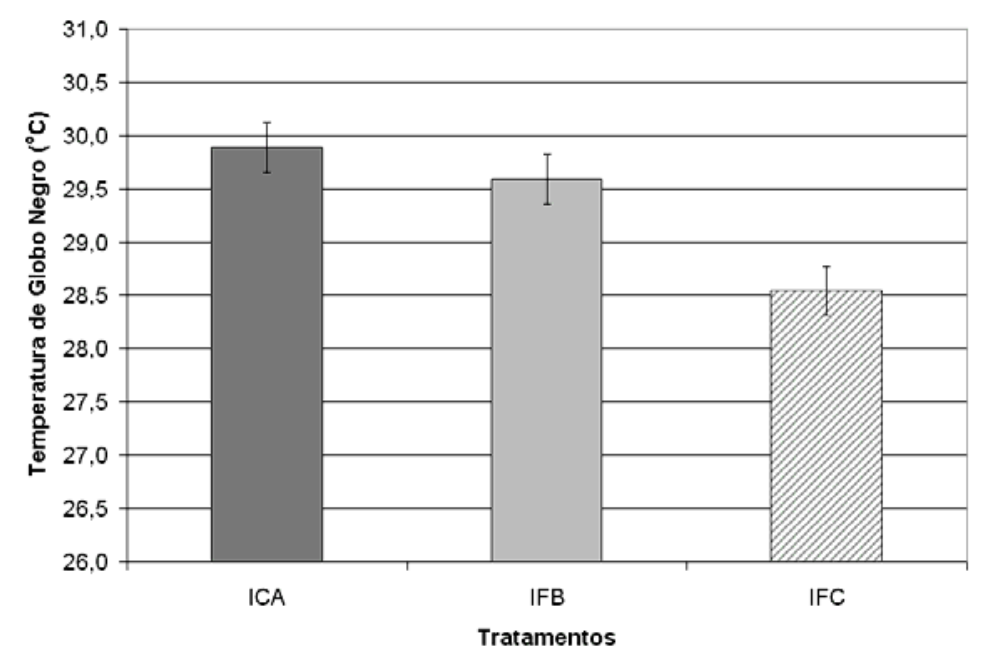

FIGURA 23. Médias de temperatura de globo negro $\left({ }^{\circ} \mathrm{C}\right)$ e erro-padrão da média dos diferentes tratamentos.

Com relação ao índice de temperatura e umidade os tratamentos IFB e IFC não apresentaram diferença entre si, com valores de 77,4 e 76,8 respectivamente.

O tratamento ICA teve valor $(78,3)$ significativamente maior $(p<0,01)$ do que os outros dois tratamentos, conforme pode ser observado na Figura 24. 0 fator que se mostrou efetivo para a diferença do ITU entre os ambientes foi o tipo de cobertura utilizado e não o sistema de climatização. No entanto, quando comparados os dois sistemas de cobertura (ICA e IFB) o melhor desempenho está associado com o tratamento coberto por telhas de cimento celulose.

A explicação para este fato, pode estar relacionada com a temperatura da superfície inferior da telha de cimento celulose, que se apresentou mais baixa que a telha de amianto. De acordo com TOLEDO (1970), citado por SILVA et al. (1990), a temperatura da telha pode influenciar e muito as condições climáticas dentro da instalação, conforme observado na Figura 20.

Para o índice de temperatura de globo e umidade (ITGU), o tratamento ICA $(79,1)$ não diferiu do tratamento IFB $(78,4)$, mas, apresentou diferença significativa $(p<0,01)$ em relação ao tratamento IFC $(77,7)$ (Figura 25). O resultado ainda mostra que, não houve diferença entre os tratamentos com telhas de fibrocimento reforçadas com fibra vegetal (IFB e IFC). Para este índice de conforto (ITGU), apenas o uso de cobertura não mostrou diferença significativa. Mas quando a cobertura de fibrocimento foi associada à 
climatização (IFC), o valor para o ITGU foi significativamente menor, se comparado ao ICA. Esses resultados estão de acordo com os obtidos para temperatura de globo negro (Figura 23), cujo menor valor de temperatura foi observado no tratamento IFC, em relação ao ambiente coberto com telha de cimento amianto (ICA).

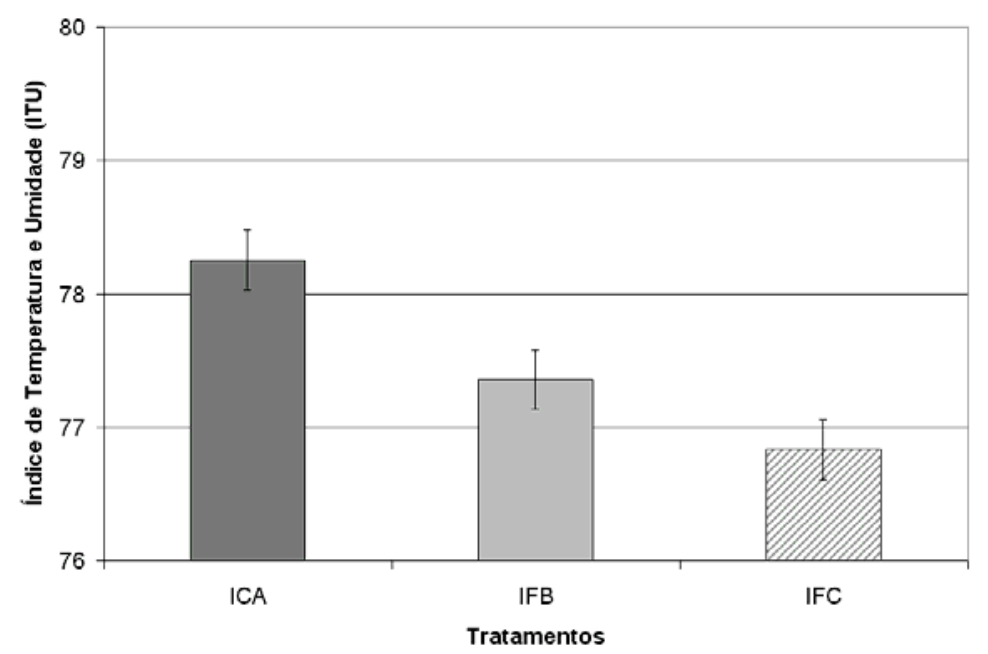

FIGURA 24. Médias do índice de temperatura e umidade (ITG) e erro-padrão da média dos diferentes tratamentos.

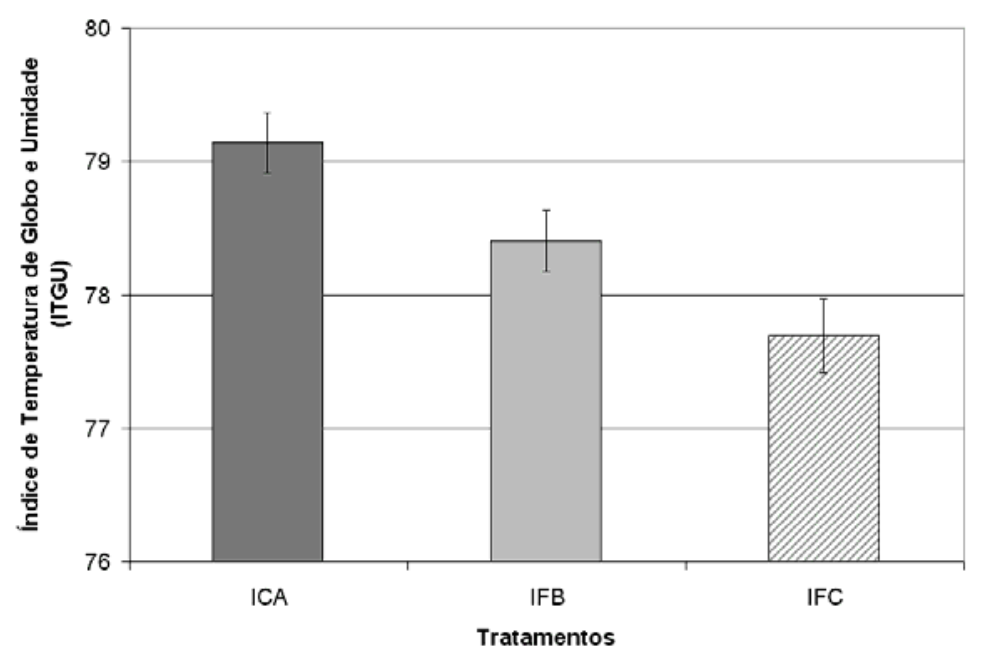

FIGURA 25. Médias do índice de temperatura de globo e umidade (ITGU) e erro-padrão da média dos diferentes tratamentos.

A Figura 26 mostra a Carga Térmica Radiante $\left(\mathrm{W} / \mathrm{m}^{2}\right)$ para os diferentes tratamentos. Como resultado, o tratamento ICA teve o valor de 488,6, o IFB de 491,5 e o IFC de $506,3 \mathrm{~W} / \mathrm{m}^{2}$. Com isso, o tratamento climatizado é indicado 
como o menos favorável, com diferença significativa em relação aos outros dois tratamentos, os quais não diferiram entre si. Isto pode ser explicado pelo uso de ventilação forçada somente neste tratamento, o que refletiu diretamente sobre o valor da carga térmica radiante. Portanto, a comparação entre ambientes com e sem ventilação forçada pode ser questionada para este parâmetro.

A entalpia presente no ambiente pode ser observada na Figura 27, sendo que os valores para ICA, IFB e IFC foram respectivamente 74,2, 70,4 e $71,7 \mathrm{~kJ} / \mathrm{kg}$ de ar seco. Os tratamentos IFB e IFC não apresentaram diferença entre si, porém, mostraram desempenho significativamente $(p<0,01)$ melhor em relação ao tratamento ICA. Este resultado demonstra o efeito do tipo de cobertura para da entalpia nas instalações. Todos os tratamentos apresentaram média da entalpia acima do valor considerado aceitável, para as condições deste trabalho, para bovinos jovens em crescimento, que é de 66,08 $\mathrm{kJ} / \mathrm{kg}$ de ar seco. Este valor está relacionado com os valores de temperatura crítica do ar e umidade relativa crítica para bovinos jovens, que são respectivamente de $25^{\circ} \mathrm{C}$ (SALEM et al., adaptado por SILVA, 2000) e $75 \%$ (KELLY et al., 1984), como descrito anteriormente no item 3.2.4.1.

A velocidade do vento apresentou interação horário $x$ tratamento, conforme observado na Figura 28, apresentando em todos os horários avaliados, o tratamento IFC com velocidade do vento no interior da instalação superior $(p<0,01)$ em relação às velocidades apresentadas nos outros dois tratamentos (ICA e IFB). Esta diferença pode ser explicada pelo presença de ventilação forçada apenas na instalação IFC. 


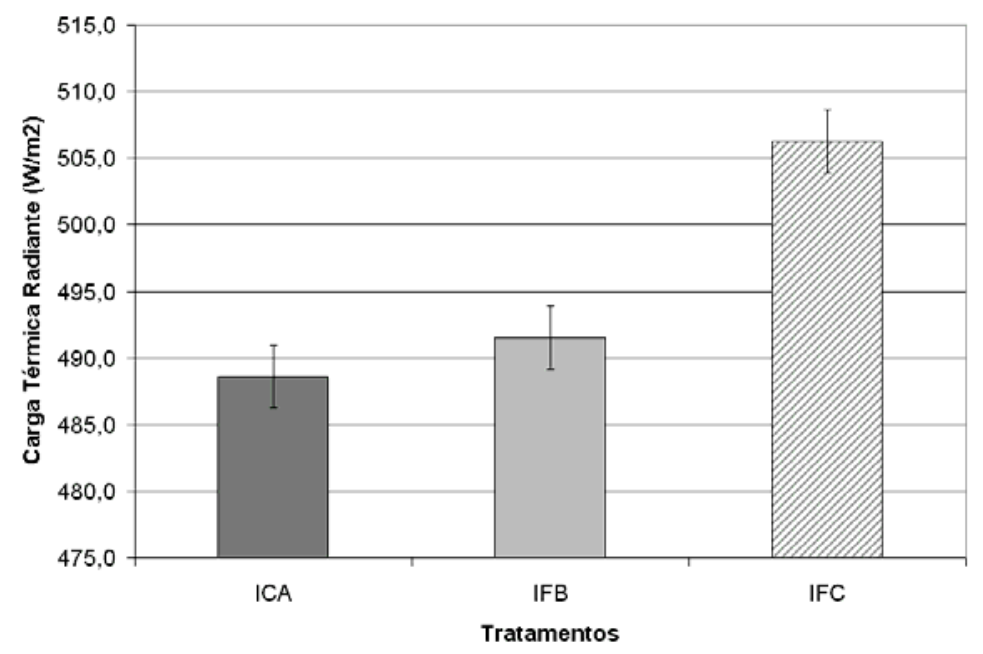

FIGURA 26. Média da carga térmica radiante $\left(\mathrm{W} / \mathrm{m}^{2}\right)$ e erropadrão da média dos diferentes tratamentos.

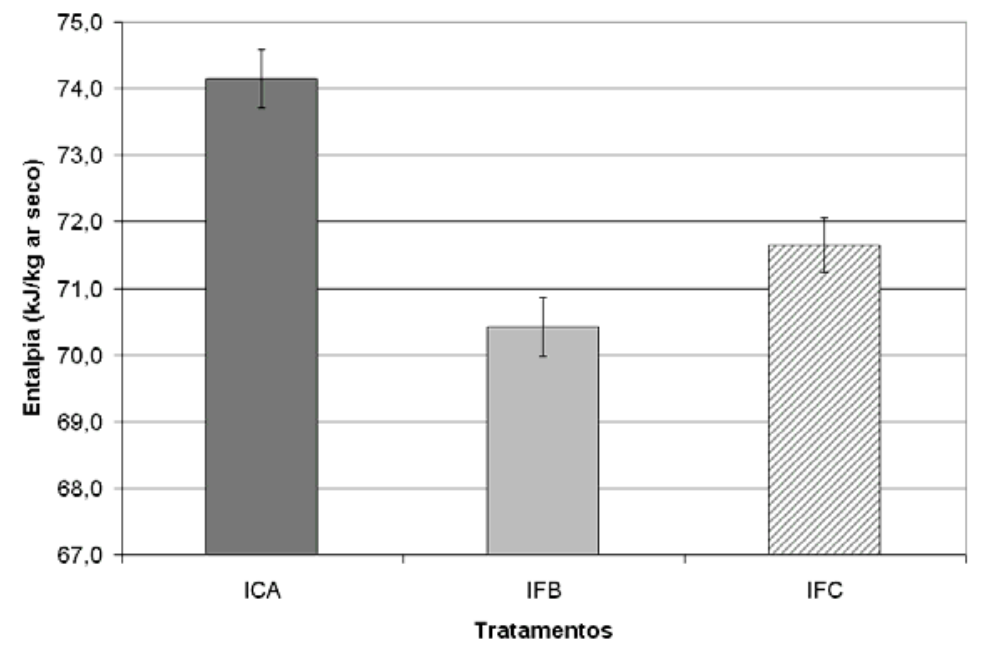

FIGURA 27. Médias dos valores de entalpia $(\mathrm{kJ} / \mathrm{kg}$ de ar seco) e erro-padrão da média dos diferentes tratamentos. 


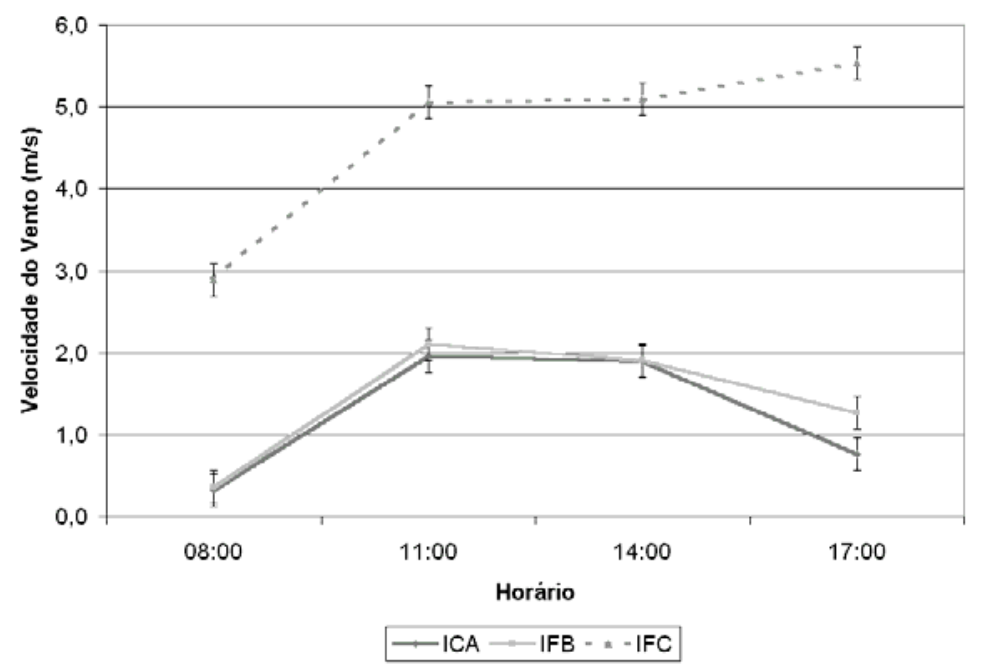

FIGURA 28. Médias da velocidade do vento $(\mathrm{m} / \mathrm{s})$ e erropadrão da média dos diferentes tratamentos nas horas estudadas.

\subsubsection{Gradiente Interno}

Para a análise dos gradientes internos numa mesma linha vertical (Figura 7), são apresentados os resultados de temperatura ambiente, umidade relativa, temperatura de globo negro e entalpia nas Figuras 29 a 32. A diferença entre os valores para a avaliação do gradiente é apresentada pela mudança de cores nas figuras. Cada alteração de cor eqüivale a uma diferença com $1 \%$ de significância.

Com relação à Temperatura Ambiente (Figura 29), pode-se observar o efeito negativo da cobertura de telha de amianto, apresentando em todas as alturas temperatura superior $(p<0,01)$ às outras instalações (IFB e IFC), porém, com diferença $(p<0,01)$ na avaliação do ambiente em relação à altura de 2,4 e $3,0 \mathrm{~m}$. O tratamento IFB não apresentou diferença em relação à altura. $O$ tratamento IFC foi diferente significativamente $(p<0,01)$ dos tratamentos ICA e IFB, para as alturas 1,8 e 2,4 m. No entanto, na altura de 3,0 m, não houve diferença entre os tratamentos IFC e IFB. Estes valores podem ser explicados pela presença da linha de nebulização a $2,4 \mathrm{~m}$ do piso. Deste ponto até a altura de $1,8 \mathrm{~m}$, o tratamento climatizado apresentou os menores valores de temperatura.

A umidade relativa para as alturas de 3,0 e $2,4 \mathrm{~m}$ se apresentou com valores mais baixos significativamente $(p<0,01)$ para o tratamento ICA, em 
relação aos tratamentos IFB e IFC (Figura 30). Para a altura de 1,8 m, foram observadas diferenças significativas entre todos os tratamentos: o tratamento IFB apresentou o menor valor, seguido do tratamento ICA e, por fim, pelo tratamento IFC, com o maior valor de umidade, em razão da climatização do ambiente.

O resultado do gradiente de temperatura de globo negro, mostra evidentemente o efeito da climatização sobre o ambiente, pois, o tratamento IFC apresentou diferença significativa em relação aos demais, para todas as alturas. A altura de 2,4m apresentou menor valor de temperatura de globo negro, conforme demonstrado na Figura 31, sendo este fato, justificado pela disposição da linha de nebulização, instalada nesta altura.

A entalpia também foi influenciada pela altura de instalação da linha de nebulização, apresentando, a 2,4 $\mathrm{m}$ de altura, diferença significativa para o tratamento IFC em relação à altura e em relação aos demais tratamentos, assim mostrado pela Figura 32.

Temperatura

Ambiente $\left({ }^{\circ} \mathrm{C}\right)$

$32-33$

$32-33$
$31-32$
$30-31$

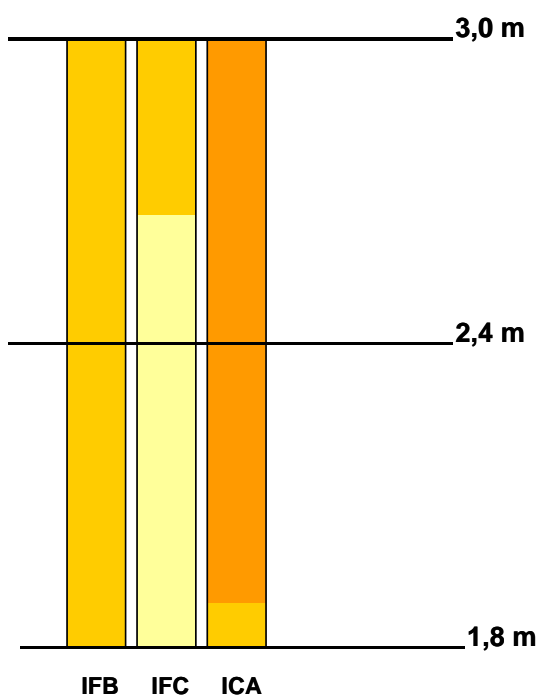

FIGURA 29. Gradiente de temperatura ambiente $\left({ }^{\circ} \mathrm{C}\right)$ no interior dos diferentes tratamentos estudados em função da altura em relação ao piso. 
Umidade Relativa (\%)

$57-61$
$53-57$

$49-53$

$49-53$
$45-49$

$45-49$

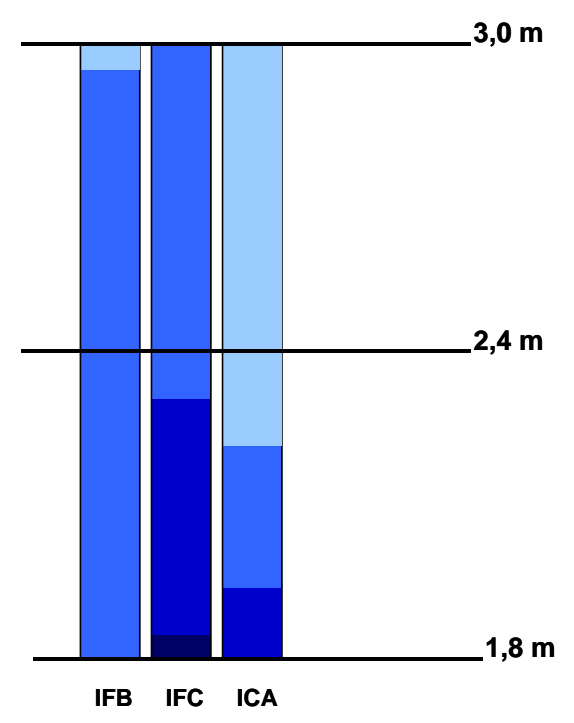

FIGURA 30. Gradiente de umidade relativa (\%) no interior dos diferentes tratamentos estudados, em função da altura em relação ao piso.

Temperatura de Globo Negro $\left({ }^{\circ} \mathrm{C}\right)$

$31,6-32,8$

$30,4-31,6$

$29,2-30,4$

$28,0-29,2$

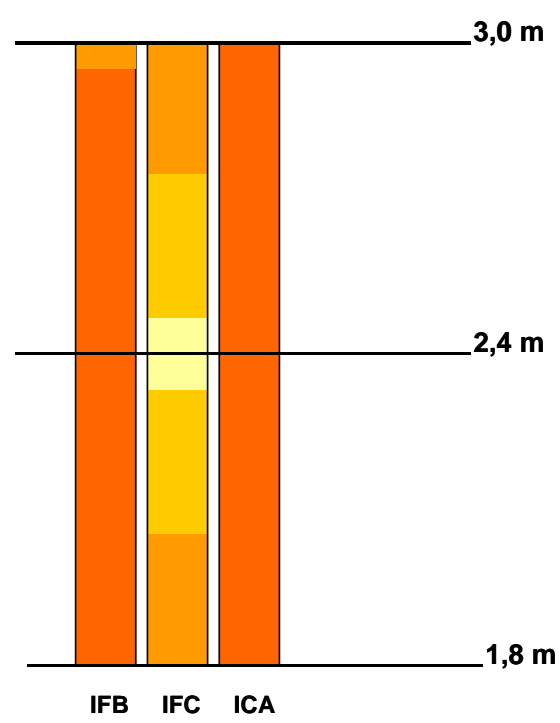

FIGURA 31. Gradiente de temperatura de globo negro $\left({ }^{\circ} \mathrm{C}\right)$ no interior dos diferentes tratamentos estudados, em função da altura em relação ao piso. 


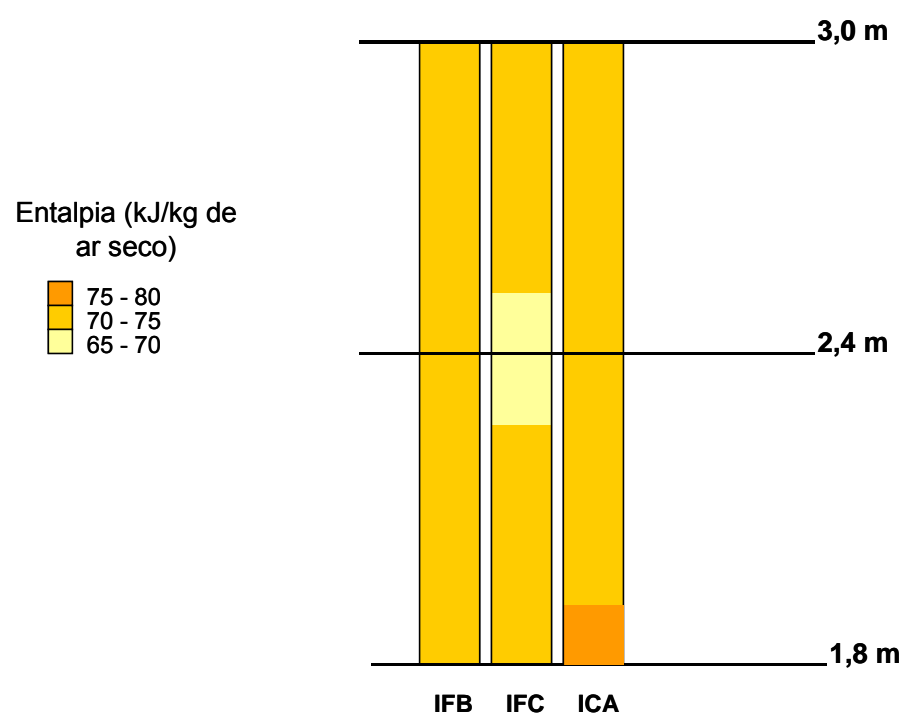

FIGURA 32. Gradiente de entalpia (kJ/kg de ar seco) no interior dos diferentes tratamentos estudados, em função da altura em relação ao piso.

\subsubsection{Desempenho Animal}

\subsubsection{Desenvolvimento dos Animais}

\section{Altura de Cernelha e Perímetro Torácico}

O cálculo de ganho de altura de cernelha durante o experimento, não apresentou nenhuma diferença entre tratamento, nem entre grupo genético. $O$ valor médio de ganho para o período foi igual a $11,5 \pm 2,4 \mathrm{~cm}$, para todos os tratamentos.

TOLEDO (2001a) demonstrou o potencial de vitelos de bezerros holandeses. Porém, os resultados do presente trabalho evidenciaram, em termos de ganho de altura de cernelha, que bezerros mestiços possuem o desempenho semelhante aos holandeses. BUVANENDRAN et al. (1982), salientaram que, por causa da impossibilidade de contenção correta dos animais, os erros de medida da altura de cernelha podem ser maiores.

O ganho em perímetro torácico apresentou diferença $(p<0,05)$ somente em relação ao grupo genético avaliado. Os animais mestiços mostraram melhor desempenho, com ganho médio de $23,3 \pm 2,8 \mathrm{~cm}$, em comparação aos animais 
holandeses com valor médio de 18,5 $\pm 2,1 \mathrm{~cm}$. Esses valores mostram que os vitelos mestiços encontraram condições mais favoráveis para o crescimento.

Segundo SINGH et al. (1978); McRAE (1986) e RIBEIRO FILHO (1991), o perímetro torácico é a medida que melhor correlaciona-se com o peso vivo dos animais, e pode evidenciar um melhor ganho de peso por parte de bezerros mestiços. A utilização de animais mestiços em rebanhos leiteiros já foi indicada por WILCOX (1992) para a melhoria na eficiência na produção de carne.

\section{Ganho de Peso e Consumo de Matéria Seca}

Para as variáveis ganho de peso e consumo de matéria seca, não forma encontradas diferenças entre os tratamentos, entretanto a diferença encontrada está relacionada com os grupos genéticos estudados.

Para o ganho de peso, foi observada superioridade significativa $(p<0,05)$ dos animais mestiços com valor de 1,71 \pm 0,2 kg/dia, em relação aos animais holandeses com ganho de peso igual a 1,32 $\pm 0,3 \mathrm{~kg} / \mathrm{dia}$. Segundo LUCCI (1989), o ganho de peso médio para animais leiteiros jovens seria de 0,861 $\mathrm{kg} /$ dia, valor este, abaixo do encontrado no presente trabalho. Uma possível explicação seria o emprego de uma dieta com alto nível de concentrado (85\% de concentrado e $15 \%$ de volumoso).

O consumo médio de matéria seca não apresentou diferença significativa em relação ao grupo genético e nem em conseqüência do tratamento, com valor médio de 3,57 $\pm 0,6 \mathrm{~kg} \mathrm{MS/dia.} \mathrm{Para} \mathrm{LUCCI} \mathrm{(1989),} \mathrm{o}$ consumo médio de matéria seca para animais leiteiros jovens seria de 4,07 kg MS/dia, valor este, condizente com o valor encontrado no presente trabalho. No entanto, é amplamente conhecido o efeito negativo do estresse calórico sobre o consumo de matéria seca (ARMSTRONG,1994; DAVIS \& MERILAN, 1960; WELDI et al., 1964 e MODDY et al., 1967). Para tentar explicar a ausência do efeito do estresse térmico sobre o consumo de matéria seca, em termos de uma possível adaptação dos animais para não ter sido observada diferença entre os tratementos, foi realizada a análise do comportamento ingestivo, com resultados apresentados na Figura 33. 
O comportamento ingestivo demonstrou que os animais de todos os tratamentos alimentaram-se principalmente entre as 6 e as $10 \mathrm{~h}$ (período de que encontrava-se o horário de oferecimento da ração, as $7 \mathrm{~h}$ ). Em torno de $50 \%$ da ingestão encontrava-se neste período. Nos períodos seguintes, o comportamento dos animais presentes no tratamento IFC não foi alterado, com média de $17 \%$ de ingestão de matéria seca (IMS) em cada um dos demais períodos. Para os tratamentos ICA e IFB, estes mostraram valores baixos (14\%) para o período das 10 às $14 \mathrm{~h}$ (horas mais quentes do dia). Na tentativa de compensar a diminuição da ingestão para o período das 10 às $14 \mathrm{~h}$, os animais dos tratamentos ICA e IFB apresentaram maior ingestão de matéria seca nos horários seguintes.

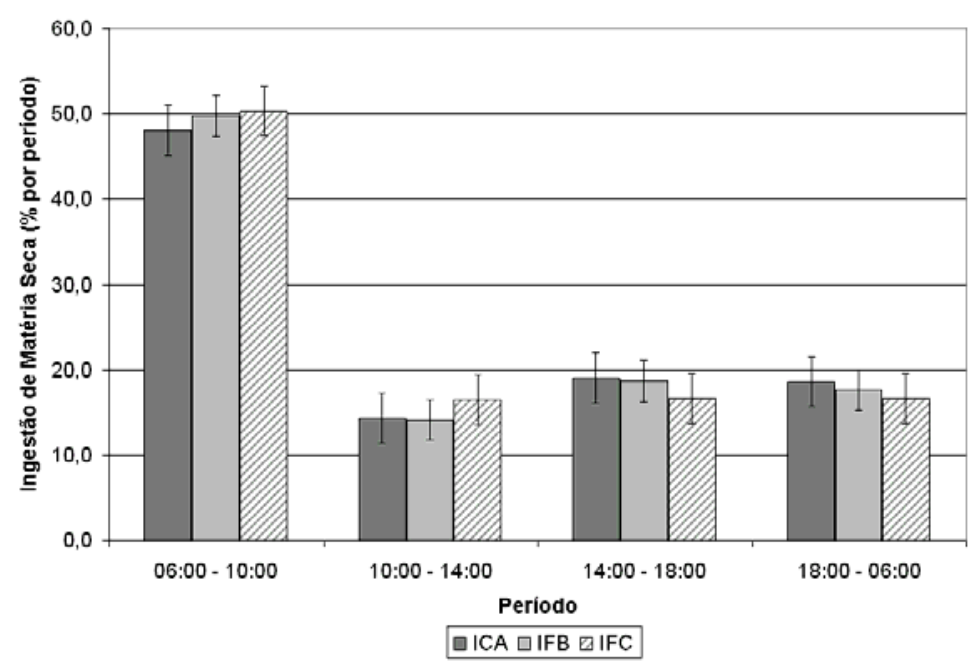

FIGURA 33. Representação do comportamento ingestivo (\%IMS/período) dos animais por tratamento, durante os períodos avaliados.

\section{Conversão Alimentar}

Os resultados de conversão alimentar não apresentaram diferenças, em relação ao tratamento, nem em razão do grupo genético, com resultados médios de 2,41 $\pm 0,86 \mathrm{~kg} \mathrm{MS} / \mathrm{kg}$ de ganho de peso. O valor referência para criação de animais jovens leiteiros para abate, segundo LUCCI (1989), seria de $4,73 \mathrm{~kg} \mathrm{MS} / \mathrm{kg}$ de ganho de peso. Portanto, os resultados apresentados pelo presente trabalho, mostram que os animais atingiram valores favoráveis, expressando seu potencial produtivo. 


\subsubsection{Variáveis Fisiológicas}

\section{Temperatura Retal}

Os resultados para a temperatura retal apresentaram interação tratamento $\mathrm{x}$ grupo genético $\mathrm{x}$ horário $\mathrm{e}$, assim, foram separados por grupos genéticos para melhor demonstração.

Para os animais holandeses, não houve diferenças entre os tratamentos, dentro de cada um dos horários avaliados, apresentando valores de temperatura retal como 39,0 (ICA), 38,9 (IFB) e $39,0^{\circ} \mathrm{C}$ (IFC) para o horário das $6 \mathrm{~h}$. Enquanto que o horário das $14 \mathrm{~h}$, os resultados foram 39,8 (ICA), 39,9 (IFB) e $39,9^{\circ} \mathrm{C}$ (IFC). Porém, quando foram comparados os valores de temperatura retal, nos horários das 8 e $14 \mathrm{~h}$ houve aumento significativo $(p<0,05)$ da temperatura retal para todos os tratamentos às $14 \mathrm{~h}$, conforme apresentado na Figura 34.

No horário das $6 \mathrm{~h}$, para os animais mestiços (Figura 35), os valores de temperatura retal foram $38,9, \quad 39,0$ e $38,8{ }^{\circ} \mathrm{C}$ para ICA, IFB e IFC respectivamente. Para o horário das $14 \mathrm{~h}$, os valores de temperatura foram $39,6,39,7$ e $39,4^{\circ} \mathrm{C}$ para ICA, IFB e IFC respectivamente. Para o horário das 6 $h$ foi apresentada diferença $(p<0,05)$ do tratamento IFB em relação aos tratamentos ICA e IFC, porém não houve diferença entre ICA e IFC. No entanto, para o horário das $14 \mathrm{~h}$, o tratamento IFB continuou apresentando maiores valores $(p<0,5)$ de temperatura retal, em relação aos outros tratamentos (IFC e ICA). Mas, no horário das $14 \mathrm{~h}$, também foi encontrada diferença $(p<0,05)$ entre os dois tratamentos (IFC e ICA), mostrando menores valores para o tratamento IFC. 


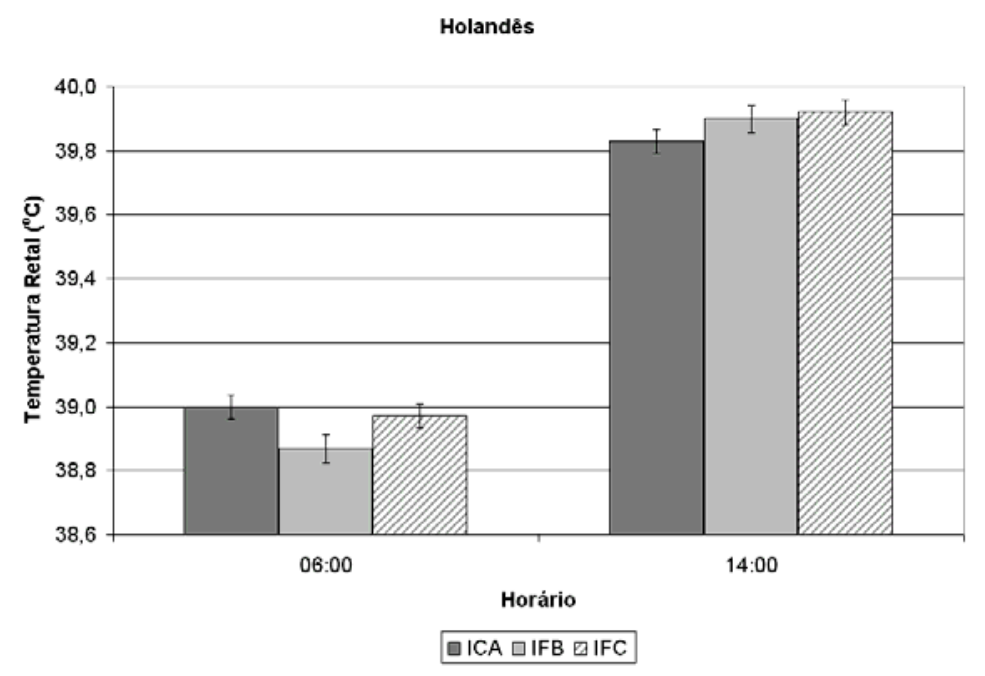

FIGURA 34. Médias de temperatura retal $\left({ }^{\circ} \mathrm{C}\right)$ e erro padrão da média dos animais holandeses nos diferentes tratamentos nos horários avaliados.

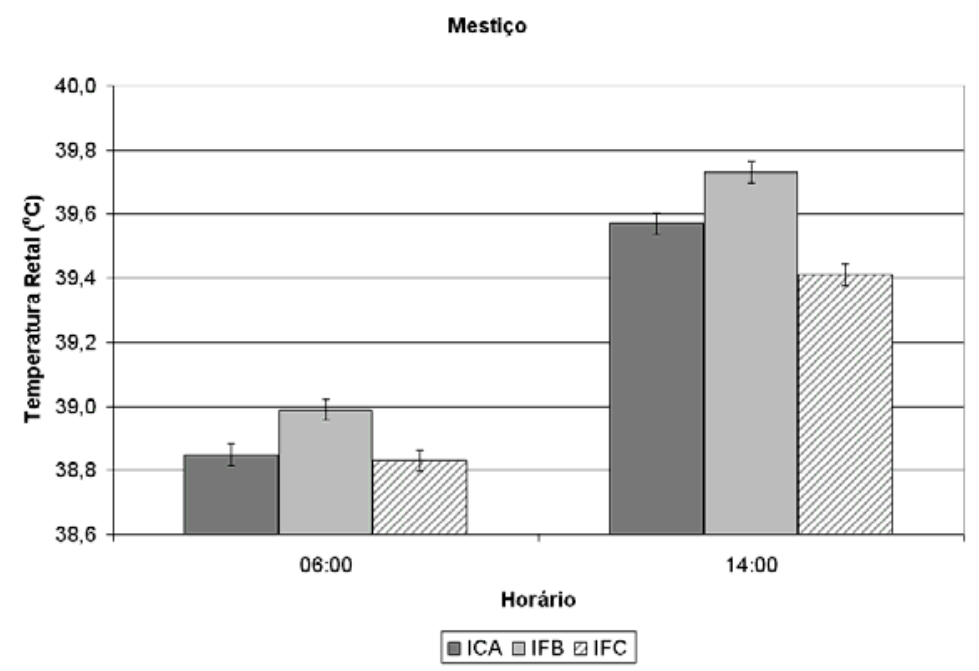

FIGURA 35. Médias de temperatura retal $\left({ }^{\circ} \mathrm{C}\right)$ e erro padrão da média dos animais mestiços nos diferentes tratamentos nos horários avaliados.

De acordo com SANTOS et al. (1975), a temperatura retal de bovinos com até 12 meses de idade pode variar de 38,5 a 40,0 $0^{\circ} \mathrm{C}$. Assim, para nenhum horário e tratamento estudado neste experimento, os animais apresentaram valores de temperatura retal anormais.

SOUZA et al. (1992) apresentaram diferenças entre temperatura retais para bezerros, em conseqüência de diferentes tipos de cobertura para instalações, bem como do horário das coletas. Porém, mesmo com esta diferença significativa, as temperaturas retais dos animais permaneceram 
dentro da faixa normal. Com isso, apresentaram as mesmas repostas encontradas no presente trabalho.

KAWABATA (2003) apresentou resultados de temperatura retal de bezerros holandeses jovens, em que não foram observadas diferenças, em razão dos diferentes tipos de cobertura utilizados em bezerreiros individuais. No presente trabalho, o tipo de cobertura também não apresentou influência sobre a temperatura retal, mas sim o uso da climatização, que obteve a influência maior sobre esta variável.

SOUZA et al (1992) relataram a influência do horário de coleta da variável temperatura retal, sendo que à tarde, sempre encontraram valor superior ao do período da manhã. Porém, os autores observaram que ambos os valores ficaram abaixo do limite crítico superior para animais leiteiros jovens. Esses resultados estão de acordo com os observados nesse trabalho, uma vez que os valores de temperatura retal às $14 \mathrm{~h}$ foram sempre maiores $(p<0,01)$ do que os das $6 \mathrm{~h}$, entretanto, permanecendo abaixo do limite crítico $\left(40,0^{\circ} \mathrm{C}\right)$.

\section{Temperatura de Pele}

Do mesmo modo que a temperatura retal, a temperatura de pele apresentou interação entre os fatores: tratamento $x$ grupo genético x horário. Com isso, também se fez necessária a análise em relação aos grupos genéticos.

Para os animais holandeses, no horário das $6 \mathrm{~h}$, o tratamento ICA apresentou média de temperatura de pele de $31,2^{\circ} \mathrm{C}$, sendo este valor maior $(p<0,05)$ que os tratamentos IFB e IFC, que ambos apresentaram valor de $30,2^{\circ} \mathrm{C}$. Às $14 \mathrm{~h}$, o tratamento com maior temperatura de pele foi o ICA, com valor de $36,8^{\circ} \mathrm{C}$, diferindo $(p<0,05)$ dos outros dois tratamentos. Os tratamentos IFB e IFC também diferiram $(p<0,05)$ entre si, às $14 \mathrm{~h}$, com valores de $36,0 \mathrm{e}$ $34,6^{\circ} \mathrm{C}$ respectivamente, conforme Figura 36.

Em contrapartida, os animais mestiços não apresentaram diferença significativa entre os tratamentos , para o horário das $6 \mathrm{~h}$, com valores de 31,6 para o IFC e $31,2^{\circ} \mathrm{C}$ para ambos tratamentos IFB e ICA (Figura 37). Às $14 \mathrm{~h}$, 0 comportamento dos tratamentos foi semelhante ao apresentado para os animais holandeses, com todos os tratamentos diferindo $(p<0,05)$ entre si. $O$ tratamento com maior valor para temperatura de pele foi o ICA $\left(36,8^{\circ} \mathrm{C}\right)$, 
seguido pelo IFB $\left(36,1^{\circ} \mathrm{C}\right)$ e, por fim, pelo tratamento IFC $\left(34,8^{\circ} \mathrm{C}\right)$. O ambiente climatizado coberto por telhas de fibrocimento reforçadas com fibras vegetais, apresentou diferenças na temperatura de pele de $2^{\circ} \mathrm{C}$, para o ambiente coberto pela telha de cimento amianto e $1,3^{\circ} \mathrm{C}$ para $\mathrm{o}$ ambiente com telhas de fibrocimento reforçadas com fibras vegetais, sem equipamento de climatização.

Trabalho realizado com vacas em lactação, observando o efeito da climatização da sala de espera sobre a temperatura de pele, apresentou uma redução da temperatura em resposta ao uso da climatização, na faixa de aproximadamente $1^{\circ} \mathrm{C}$ (PINHEIRO et al., 2000). Este resultado mostra o efeito da climatização sobre a temperatura de pele, e está de acordo com o presente trabalho, que também mostrou o efeito positivo da climatização, diminuindo a temperatura de pele, seja dos animais mestiços, seja dos animais holandeses.

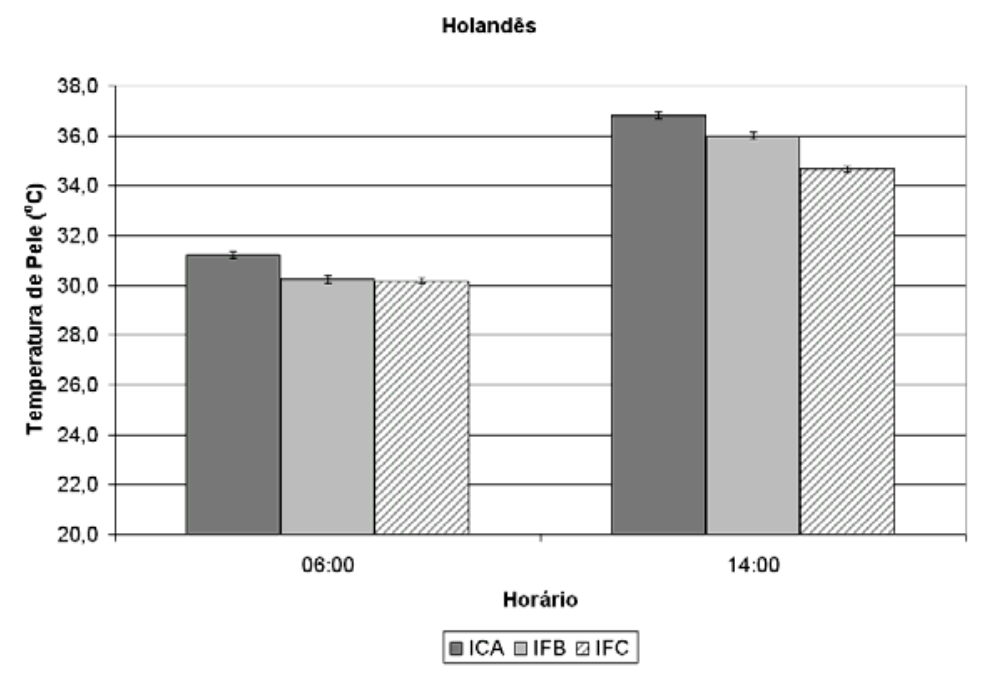

FIGURA 36. Médias de temperatura de pele $\left({ }^{\circ} \mathrm{C}\right)$ e erro padrão da média dos animais holandeses nos diferentes tratamentos para os horários avaliados. 


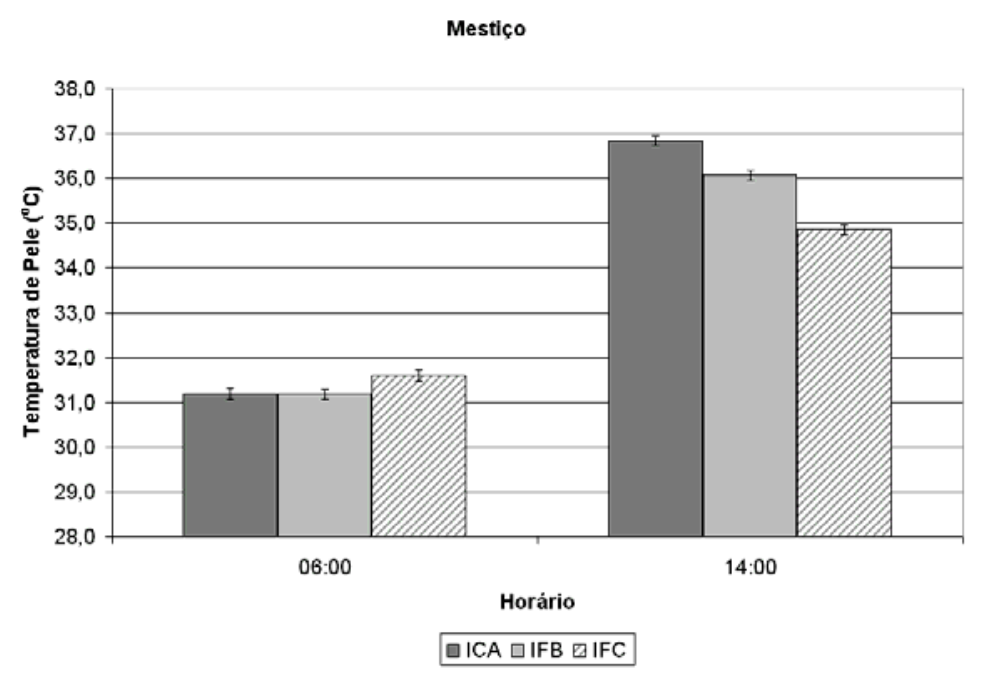

FIGURA 37. Médias de temperatura de pele $\left({ }^{\circ} \mathrm{C}\right)$ e erro padrão da média dos animais mestiços nos diferentes tratamentos para os horários avaliados.

\section{Freqüência Respiratória}

Os valores de freqüência respiratória apresentaram apenas efeito da interação tratamento $\mathrm{x}$ horário $\mathrm{e}$, assim, não se observou efeito do grupo genético. No horário das $6 \mathrm{~h}$, o tratamento ICA apresentou valor 54 , o IFB de 53 e o IFC de $52 \mathrm{mov} / \mathrm{min}$. Enquanto que para o horário das $14 \mathrm{~h}$, os valores encontrados foram respectivamente de 94,92 e $80 \mathrm{mov} / \mathrm{min}$, para os tratamentos ICA, IFB e IFC.

Como resultado da análise feita, às $6 \mathrm{~h}$, não foram encontradas diferenças entre os tratamentos. Para o horário das $14 \mathrm{~h}$, os tratamentos ICA e IFB não diferiram entre si, porém diferiram $(p<0,05)$ do tratamento climatizado (IFC). Também foi observado o efeito do horário sobre a freqüência respiratória, com aumento significativo para o período mais quente do dia, conforme Figura 38.

KAWABATA (2003) relatou que a variável fisiológica que correlaciona-se melhor com os índices de conforto, é a freqüência respiratória. $O$ presente trabalho demonstra a diferença do uso de climatização em comparação aos ambientes sem este equipamento, com diminuição da freqüência respiratória dos animais.

SOUZA et al (1992) relataram a média da freqüência respiratória de bezerros submetidos a diferentes tipos de bezerreiros de 44 e $52 \mathrm{mov} / \mathrm{min}$ 
respectivamente para o período da manhã e da tarde, com diferença significativa. No presente trabalho também foi encontrada diferença entre os horários de coleta da variável. Porém os valores de freqüência respiratória encontrados por SOUZA et al (1992), que mostraram se encontram abaixo dos valores apresentados neste estudo.

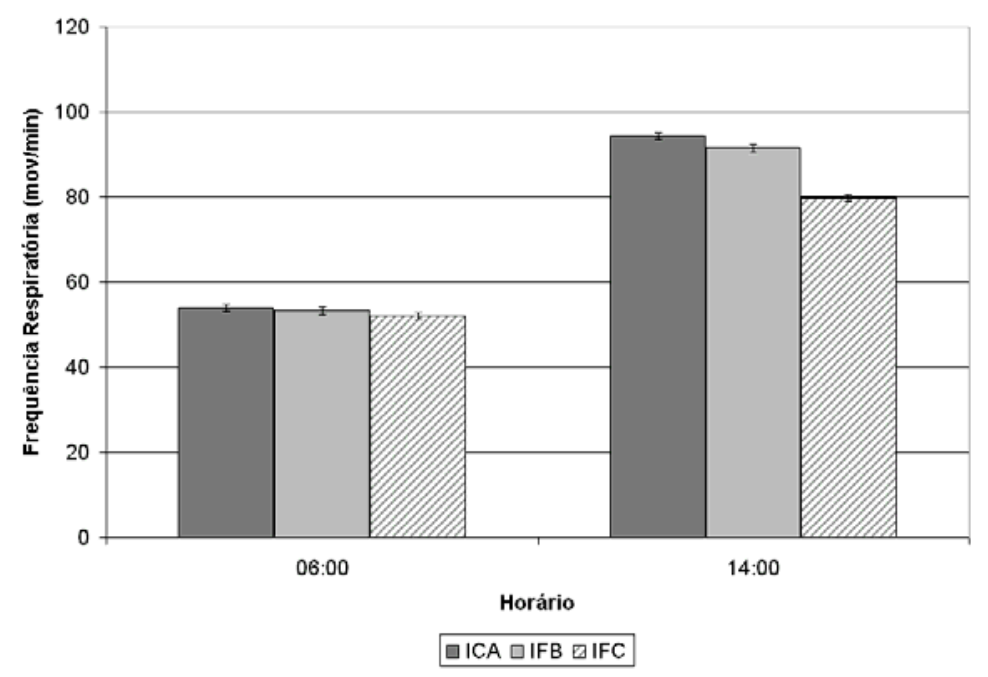

FIGURA 38. Médias de freqüência respiratória ( $\mathrm{mov} / \mathrm{min}$ ) e erro padrão da média dos animais nos diferentes tratamentos em função dos horários avaliados.

SOUZA et al (1992) ainda observaram diferença das frequências respiratórias nos animais, em função do tipo de bezerreiros utilizados, mostrando o efeito do ambiente sobre esta variável. PINHEIRO et al. (2001) relataram o efeito da climatização sobre a freqüência respiratória de vacas em lactação e apresentaram o efeito do horário, bem como o efeito da climatização. A climatização diminuiu em 15 movimentos por minuto a freqüência respiratoria dos animais.

No presente trabalho, também foi observada uma redução na frequência respiratória em função do uso da climatização no ambiente (IFC). Esta redução variou de 13 a $15 \mathrm{mov} / \mathrm{min}$ do ambiente climatizado (IFC) em relação aos outros dois tratamentos (IFB e ICA).

A diferença entre as freqüências respiratórias podem ter influenciado outras variáveis, como a temperatura retal. Como os animais da instalação ICA 
apresentaram maiores valores de freqüência respiratória, este fato pode ter ajudado a diminuir a temperatura retal.

\subsubsection{Parâmetros Sangüíneos}

Os valores de hematócrito apresentaram o efeito do grupo genético e estão de acordo com a literatura (D'ANGELINO et al., 1977 e NICOLETTI et al., 1981, citados por BENESI, 1983). Para os animais mestiços, o valor médio foi de $33,75 \pm 2,7 \%$, diferindo $(p<0,01)$ dos holandeses, com valor médio de 29,72 $\pm 3,8 \%$.

Para a hemoglobina, os animais holandeses apresentaram valor médio de $10,20 \pm 0,4 \mathrm{~g} / \mathrm{dL}$, valor esse menor $(p<0,01)$ que o dos mestiços, que foi de $11,14 \pm 0,6 \mathrm{~g} / \mathrm{dL}$. Esses valores se apresentam dentro do padrão normal de hemoglobina no sangue, que é de 9,90 $\pm 1,1 \mathrm{~g} / \mathrm{dL}$ para animais holandeses e 12,2 \pm 1,2g/dL (D'ANGELINO et al., 1977 e NICOLETTI et al., 1981, citados por BENESI, 1983)

Os níveis de uréia, presentes no plasma sangüíneo dos animais, não apresentaram nenhuma variação significativa, com valores em média de 23,4 \pm $7,0 \mathrm{mg} / \mathrm{dL}$. SWENSON (1993) relatou os valores médios normais para bovinos de 10 a $30 \mathrm{mg} / \mathrm{dL}$.

O valor médio para os níveis de creatinina foi igual a $1,3 \pm 0,2 \mathrm{mg} / \mathrm{dL}$, sem diferença significativa entre tratamento e nem entre grupo genético. SWENSON (1993) propôs como faixa ótima os valores de creatinina compreendidos entre 1 e $2 \mathrm{mg} / \mathrm{dL}$.

Para nenhum dos parâmetros avaliados foram encontradas diferenças significativas em relação ao tratamento. Tal resposta discorda dos resultados de trabalho feito por CAMPOS NETO (1984), que concluiu que o estresse térmico provocou a diminuição dos valores de hematócrito e uréia, e aumento de creatinina sérica. 


\subsubsection{Variáveis Produtivas}

Não foram observadas diferenças entre os tratamentos e grupos genéticos para o $\mathrm{pH}$ e a temperatura das carcaças, em nenhum horário avaliado. No momento $0 \mathrm{~h}, \mathrm{o} \mathrm{pH}$ foi de 6,5 \pm 0,2 e a temperatura de carcaça, de $35,3 \pm 2,6^{\circ} \mathrm{C}$. Após o resfriamento de $30 \mathrm{~h}, \mathrm{o} \mathrm{pH}$ encontrado foi de 5,5 $\pm 0,1$ e a temperatura de carcaça, de $9,0 \pm 2,3^{\circ} \mathrm{C}$.

As variáveis relacionadas com a produção de carne de vitelo foram divididas em dois grupos: quantitativas e qualitativas.

Quantitativas envolvem peso de carcaça quente (PCQ), rendimento de carcaça, área de olho de lombo (AOL), espessura de gordura subcutânea e porcentagem de carne na carcaça. Qualitativas englobam textura e coloração da carne.

\subsubsection{Quantitativas}

Em relação ao peso de carcaça quente (PCQ), não foi observada diferença significativa entre os tratamentos, nem para os grupos genéticos. Uma possível explicação seria a alta variação dos registros. O tratamento ICA produziu animais com peso médio de $80,8 \pm 16,8 \mathrm{~kg} /$ carcaça, o tratamento IFC, com $76,3 \pm 17,0 \mathrm{~kg}$ e o IFB, com $67,8 \pm 17,4 \mathrm{~kg}$. Do mesmo modo, na comparação do valor médio por grupo genético, os animais mestiços produziram, em média, carcaças de 79,9 \pm 9,7 kg, enquanto os holandeses, de $70,0 \pm 16,9 \mathrm{~kg}$ (Figura 39). 


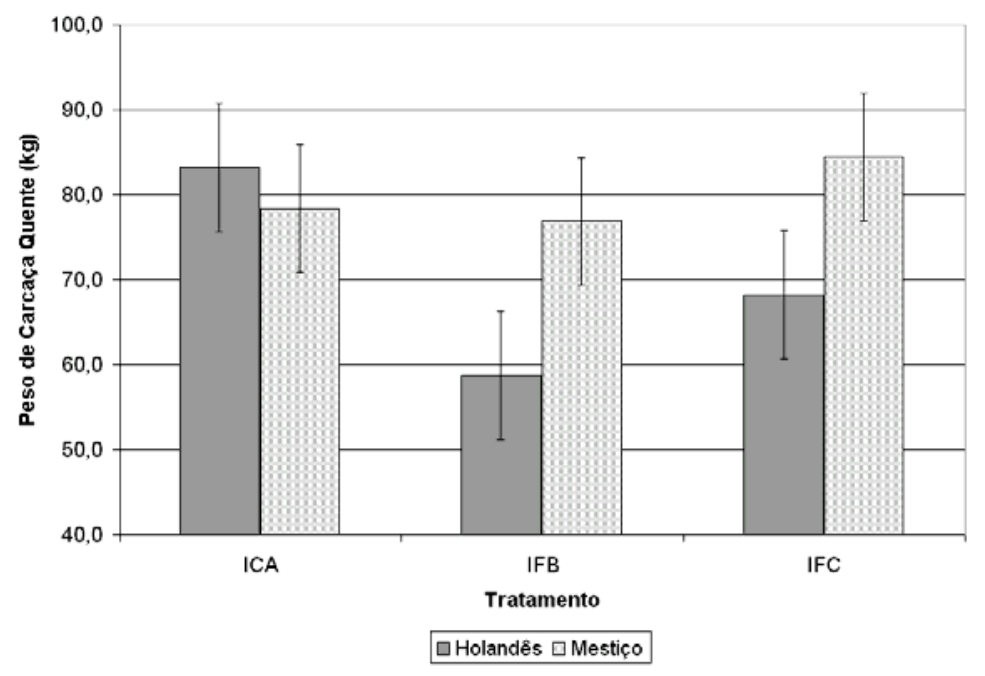

FIGURA 39. Médias do peso de carcaça quente $(\mathrm{kg})$ e erro padrão da média dos grupos genéticos nos diferentes tratamentos.

O rendimento médio de carcaça foi de $46,6 \pm 1,8 \%$ e também não apresentou diferença em relação aos tratamentos e nem quanto ao grupo genético. Mas, ao contrário do peso de carcaça quente, não apresentou grandes variações nos resultados. Os valores de rendimento se mostraram abaixo daqueles de outros trabalhos com vitelos holandeses (WILSON et al., 1995 e SALLES \& LUCCI, 2000). BREIDENSTEIN et al. (1965) e GUENTHER et al. (1965), citados por BERG \& BUTTERFIELD (1979), apresentaram resultados de animais adultos com maiores rendimentos de carcaça alimentados com dietas com alto teor de concentrado. Porém, esses aumentos nos rendimentos foram associados à deposição de gordura. HELSER et al. (1930), CALLOW (1949) e GOOD et al. (1961), citados por PRESTON \& WILLIS (1974), mostram que o determinante no rendimento de carcaça é a gordura de cobertura. Mesmo com alta relação concentrado:volumoso na dieta do presente experimento, os vitelos apresentaram menores valores de rendimento, possivelmente pela baixa deposição de gordura, característica esta, intrínseca na produção de vitelo.O parâmetro área de olho de lombo (AOL) apresentou valor médio de $35,5 \pm 3,8 \mathrm{~cm}^{2}$, sem diferença significativa entre tratamentos. A espessura de gordura subcutânea não foi mensurada pela ausência ou mínima camada de gordura na carne. 
Para a porcentagem de carne na carcaça, foi encontrada uma interação tratamento $\mathrm{x}$ grupo genético. Os resultados da porcentagem de carne na carcaça podem ser vistos na Figura 40. Os animais mestiços não apresentaram diferença $(p<0,05)$ entre si na comparação entre tratamentos, obtendo valores de 67,7 (ICA), 68,3 (IFB) e 67,6\% (IFC). Para os animais holandeses, os valores foram de 66,7 (ICA), 65,6 (IFB) e 62,8\% (IFC), sendo que ICA não diferiu do IFB, porém foi maior $(p<0,05)$ do que o IFC. Os tratamentos IFB e IFC apresentaram diferença significativa $(p<0,05)$ entre si.

De acordo com estes resultados, o microclima das instalações parece não ter influenciado nas percentagens de carne na carcaça dos mestiços, já que estes apresentaram valores semelhantes para todos os tratamentos.

Com relação aos animais holandeses, o menor valor de porcentagem de carne na carcaça para o tratamento IFC, não pôde ser relacionado com o efeito do ambiente, uma vez que, os dados fisiológicos dos animais alojados nesta instalação não caracterizaram condição de estresse térmico. Muitas foram as variáveis que podem ter influenciado a porcentagem de carne na carcaça, como manejo dos animais antes do início do trabalho e genética.

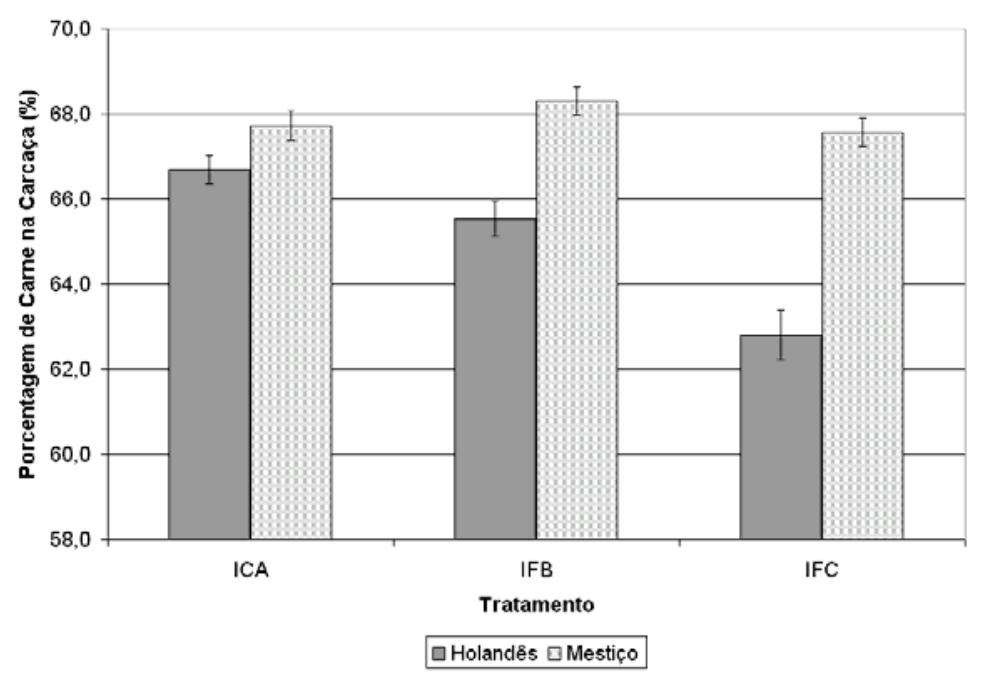

FIGURA 40. Médias de porcentagem de carne na carcaça e erro padrão da média dos grupos genéticos nos diferentes tratamentos.

\subsubsection{Qualitativas}

Quanto à coloração das amostras de carne, os resultados foram apresentados em termos das escalas $L^{*}$, $a^{*} e b^{*}$ (ver item 3.2.4.5). Para as 
escalas $L^{*}$ e $b^{*}$, não foram observadas diferenças entre os tratamentos e entre os grupos genéticos.

Em relação à escala $a^{*}$, relacionada com a coloração, que varia do verde (-) ao vermelho (+), não foram observados efeitos dos tratamentos. Em contrapartida, o efeito do grupo genético foi significante $(p<0,05)$, pois a carne de vitelos mestiços teve coloração mais avermelhada que a carne de vitelos holandeses (Figura 41). A coloração é um fator importante na determinação do preço da carne de vitelo, apresentando-se como mais valorizada a carne menos avermelhada, conforme citado por MCKEITH \& WILSON (1994).

Para análise da textura, assim como da escala de coloração $a^{*}$, somente o grupo genético apresentou efeito significativo $(p<0,05)$. A carne de vitelos mestiços obteve valor de textura igual a $1,25 \mathrm{~kg}$ com o aparelho WarnerBratzler, mais macia $(p<0,05)$ portanto que a dos holandeses, com valor de $1,57 \mathrm{~kg}$.

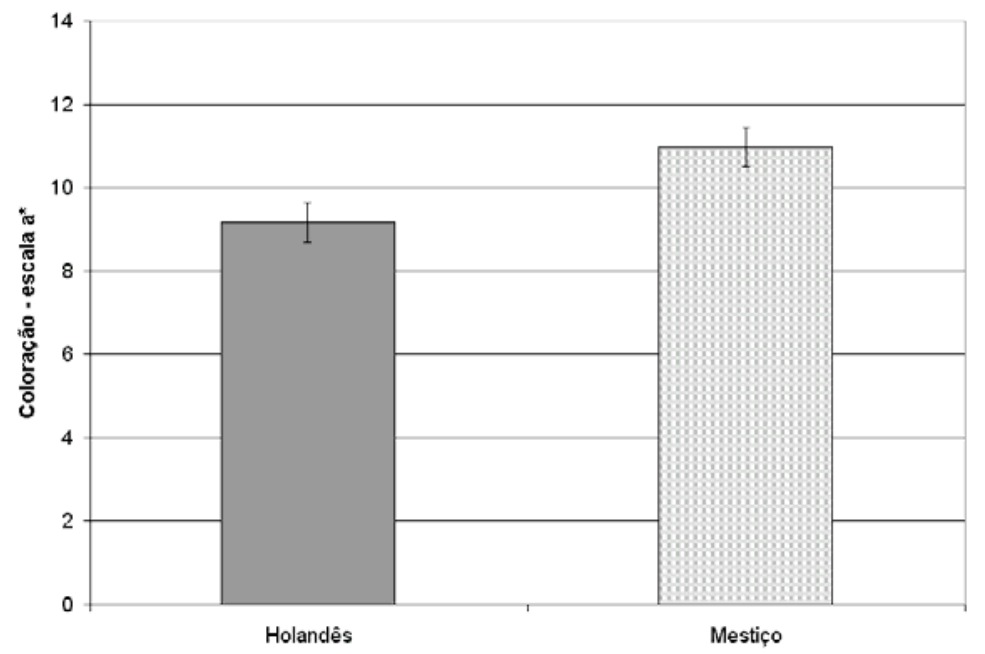

FIGURA 41. Médias dos valores de coloração na escala $a^{*} e$ erro padrão da média em função do grupo genético.

\subsubsection{Aspectos Econômicos}

Como resposta da análise econômica, são apresentados valores em termos de custo de produção por quilo de carne de vitelo.

A Tabela 9, apresenta os valores de investimentos por instalação, com depreciação para o período de quatro meses. Na Tabela 10, são apresentados 
os valores de custo fixo, variável e total para cada grupo genético dentro de cada instalação. Porém, como a instalação durante o experimento estava subutilizada, fez-se o cálculo para a sua máxima utilização, até 12 animais por instalação. Ainda na Tabela 10, são apresentados os valores de produção de carne e o custo médio por quilo de carne produzida.

TABELA 9. Investimentos realizados nos diferentes tratamentos.

\begin{tabular}{|c|c|c|c|c|}
\hline INVESTIMENTOS & $\begin{array}{l}\text { Custo } \\
\text { (R\$) }\end{array}$ & $\begin{array}{l}\text { Vida Útil } \\
\text { (meses) }\end{array}$ & $\begin{array}{l}\text { Depreciação } \\
\text { Mensal (R\$) }\end{array}$ & $\begin{array}{c}\text { Depreciação } \\
\text { Total (R\$) * }\end{array}$ \\
\hline & IFB & & & \\
\hline Bebedouro & 155,00 & 180 & 0,86 & $\overline{3,44}$ \\
\hline Comedouro & 700,00 & 120 & 5,83 & 23,33 \\
\hline Estrutura Instalação (piso, colunas e telhado) & 2591,45 & 240 & 10,80 & 43,19 \\
\hline \multirow[t]{3}{*}{ Telhas } & 403,00 & 60 & 6,72 & 26,87 \\
\hline & & & & 96,84 \\
\hline & $\overline{I C A}$ & & & \\
\hline Bebedouro & 155,00 & 180 & 0,86 & 3,44 \\
\hline Comedouro & 700,00 & 120 & 5,83 & 23,33 \\
\hline Estrutura Instalação (piso, colunas e telhado) & 1653,95 & 240 & 6,89 & 27,57 \\
\hline \multirow[t]{3}{*}{ Telhas } & 993,52 & 240 & 4,14 & 16,56 \\
\hline & & & & 70,90 \\
\hline & IFC & & & \\
\hline Bebedouro & 155,00 & 180 & 0,86 & 3,44 \\
\hline Comedouro & 700,00 & 120 & 5,83 & 23,33 \\
\hline Estrutura Instalação (piso, colunas e telhado) & 2591,45 & 240 & 10,80 & 43,19 \\
\hline Telhas & 403,00 & 60 & 6,72 & 26,87 \\
\hline Nebulização (equipamento e instalação) & 5223,00 & 96 & 54,41 & 217,63 \\
\hline \multirow[t]{2}{*}{ Ventilação (equipamento e instalação) } & 421,00 & 180 & 2,34 & 9,36 \\
\hline & & & & 323,82 \\
\hline
\end{tabular}


TABELA 10. Custos de produção ( $R \$ / k g$ de carne) por tratamento e por grupo genético.

\begin{tabular}{|c|c|c|c|c|c|c|}
\hline & IFB - M & IFB - H & IFC - M & IFC - H & ICA - M & ICA - H \\
\hline \multicolumn{7}{|c|}{ CUSTOS VARIÁVEIS (R\$) } \\
\hline Bezerro & 834,00 & 834,00 & 834,00 & 834,00 & 834,00 & 834,00 \\
\hline Ração & 914,76 & 784,64 & 940,57 & 879,14 & 983,69 & 1063,37 \\
\hline Água & 2,81 & 2,81 & 2,81 & 2,81 & 2,81 & 2,81 \\
\hline Medicamento & 43,81 & 43,81 & 43,81 & 43,81 & 43,81 & 43,81 \\
\hline TOTAL & 1795,38 & 1665,26 & 1821,19 & 1759,77 & 1864,31 & 1944,00 \\
\hline \multicolumn{7}{|l|}{ CUSTOS FIXOS (R\$) } \\
\hline$\overline{\text { Água }}$ & & & 1,86 & 1,86 & & \\
\hline Energia & & & 39,75 & 39,75 & & \\
\hline Mão de Obra & 150,00 & 150,00 & 150,00 & 150,00 & 150,00 & 150,00 \\
\hline Depreciação * & 48,42 & 48,42 & 161,91 & 161,91 & 35,45 & 35,45 \\
\hline TOTAL & 198,42 & 198,42 & 353,51 & 353,51 & 185,45 & 185,45 \\
\hline CUSTO TOTAL (R\$) ** & 1993,80 & 1863,68 & 2174,70 & 2113,28 & 2049,76 & 2129,45 \\
\hline
\end{tabular}

\begin{tabular}{lcccccc}
\hline PRODUÇÁO & IFB - M & IFB - H & IFC - M & IFC - H & ICA - M & ICA - H \\
\hline kg carne & 306,78 & 223,80 & 334,48 & 252,00 & 311,36 & 324,46 \\
\hline CUSTO MÉDIO *** & IFB - M & IFB - H & IFC - M & IFC - H & ICA - M & ICA - H \\
\hline R\$lkg carne & $\mathbf{6 , 5 0}$ & $\mathbf{8 , 3 3}$ & $\mathbf{6 , 5 0}$ & $\mathbf{8 , 3 9}$ & $\mathbf{6 , 5 8}$ & $\mathbf{6 , 5 6}$
\end{tabular}

* Referente a metade do valor de depreciação calculado na tabela 9, para cada tratamento

** Custo Total $=$ Custos Variáveis + Custos Fixos

*** Custo Médio $=$ Custo Total $/$ Produção

Como resultado final, para as condições deste experimento, em relação à análise econômica, os animais mestiços não apresentaram grande variação no custo por quilo de carne produzida em função do tratamento, com valores entre $R \$ 6,50$ e $R \$ 6,58$ por quilo de carne. Para os animais holandeses, o menor custo de produção foi encontrado na instalação composta de telhas de cimento amianto, com valor de $\mathrm{R} \$ 6,56$ por quilo de carne. As instalações IFB e IFC apresentaram valores de $\mathrm{R} \$ 8,33$ e $\mathrm{R} \$ 8,39$ por quilo de carne respectivamente. 


\section{CONCLUSÕES}

O estudo da utilização de resíduos vegetais na produção de telhas se encontra em andamento, com a finalidade de preservar o reforço fibroso na matriz cimentícia. No entanto, as telhas de cimento celulose são indicadas, principalmente nas instalações rurais, como alternativa ao cimento amianto. Esta consideração pode ser feita com base nos resultados de análise física do ambiente, no que se refere a temperatura ambiente, umidade relativa e temperatura de globo (radiação). Os ambientes cobertos pelas telhas de cimento celulose tiveram um desempenho melhor que o ambiente com telha de cimento amianto.

A climatização melhorou o ambiente e afetou diretamente os parâmetros fisiológicos dos animais, como temperatura de pele, temperatura retal e freqüência respiratória. Porém, mesmo com a alteração do ambiente pelo tipo de cobertura e pelo sistema de climatização, não foram observadas respostas nos parâmetros produtivos, em decorrência do ambiente. Uma possível explicação seria o experimento em ambientes abertos, com muita influência das intempéries climáticas externas. Talvez houvesse maior diferenciação entre os resultados dos tratamentos se as instalações fossem apenas parcialmente abertas.

Foi observada diferença na produção em relação ao grupo genético avaliado. Evidenciou-se o potencial dos bezerros provenientes de rebanhos mestiços para a produção de vitelos, com carne um pouco mais escura (aspecto indesejável), no entanto, sem cobertura de gordura e um pouco mais macia, o que pode ser valorizado.

A análise econômica, para as condições deste experimento, não apresentou diferença nos custos produtivos dos animais mestiços em relação ao tipo de instalação. Esses valores ficaram compreendidos entre $R \$ 6,50$ e 
$\mathrm{R} \$ 6,58$ por quilo de carne produzida. Os animais da raça Holandesa tiveram menor custo de produção na instalação com telha de cimento amianto $(\mathrm{R} \$ 6,56 / \mathrm{kg})$, porém equivalente ao da produção de vitelos mestiços.

Tais resultados indicam um potencial para a produção de vitelos, mestiços ou holandeses, como fonte de renda extra para os produtores de leite, a partir da venda de carne. 


\section{BIBLIOGRAFIA}

ABNT. Associação Brasileira de Normas Técnicas. NBR -5735 . Cimento Portland de alto forno. Rio de Janeiro: ABNT, 1991.

ABNT. Associação Brasileira de Normas Técnicas. NBR - 7581. Telha ondulada de fibrocimento. Rio de Janeiro: ABNT, 1993.

ABNT. Associação Brasileira de Normas Técnicas. NBR-7215. Cimento Portland - determinação da resistência à compressão. Rio de Janeiro: ABNT, 1996.

ABULARACH, M.L.S.; ROCHA, C.E. FELICIO, P.E. Características de qualidade do contra-filé ( $m$. L. dorsi) de touros jovens da raça Nelore. Ciência e Tecnologia de Alimentos, v. 18, n. 2, p. 205-210, 1998.

AGOPYAN, V. Materiais reforçados com fibras para a construção civil nos países em desenvolvimento: o uso de fibras vegetais. 1991. 204 p. Tese (Livre-Docência) - Escola Politécnica, Universidade de São Paulo, São Paulo.

ALLEONI, G.F.; ABRAMIDES, P.L.G.; MATTOS, H.B. Efeito da suplementação protéica na performance de bovinos machos leiteiros mantidos em pasto consorciado. Boletim da Indústria Animal, v. 37, n. 1, p. 33-45, 1980.

ALVES, P.A.M.; LIZIEIRE, R.S. Teste de um sucedâneo na produção de vitelos. Revista Brasileira de Zootecnia, v. 30, n. 3, p. 817-823, maio/jun. 2001.

ARMSTRONG, D.V. Heat stress interaction with shade and cooling. Journal Dairy Science, v. 77, n. 7, p. 2044-2050, 1994.

ARMSTRONG, D.V.; WELCHERT, P.E. Dairy cattle housing to reduce stress in a hot-arid climate. In: INTERNACIONAL DAIRY HOUSING CONFERENCE, 3., 1994, Orlando, FL, USA. Abstracts... ASAE, 1994. p. 598-604. 
BACCARI JUNIOR, F. Adaptação de sistemas de manejo na produção de leite em clima quente. In: SIMPÓSIO BRASILEIRO DE AMBIÊNCIA NA PRODUÇÃO DE LEITE, 1998, Piracicaba. Anais... Piracicaba: FEALQ, 1998. p. 24-67.

BAÊTA, F.C. Responses of lactating dairy cows to the combined effects of temperature, humidity and Wind velocity in the warm season. 1985. $218 \mathrm{p}$. (Ph.D. Thesis) - Missouri, University of Missouri - Columbia.

BAÊTA, F.C.; SOUZA, C.F. Ambiência em edificações rurais: conforto animal. Viçosa: UFV, 1997. $246 \mathrm{p}$.

BAKER, M.A. Effect of dehydration and rehydration on thermoregulatory sweating in goats. Journal of Physiology, London, v. 417, p. 421-435, 1989.

BENESI, F.J. Valores hematológicos de animais domésticos normais, criados em São Paulo. In: BIRGEL, E.H.; BENESI, F.J. Patologia clínica veterinária. São Paulo: Sociedade Paulista de Medicina Veterinária, 1983. p. 63-69.

BENTUR A.; AKERS, S.A.S. The microstructure and ageing of cellulose fibre reinforced cement composites cured in a normal environment. International Journal of Cement Composites and Lightweight Concrete, v. 11, n. 2, p. 99-109, 1989.

BIGGS, H. G.; COOPER. J.M. Clinical chemistry, v. 7, n. 6, p. 655, 1961.

BLAZQUEZ, N.B.; LONG, S.E.; MAYHEW, T.M.; et al. Rate of discharge and morphology of sweat glands in the perineal, lumbodorsal and scrotal skin of cattle. Research Veterinary Science, v. 57, p. 277-284, 1994.

BLINCOE, C.; BRODY, S. The influence of temperature on blood composition of cattle. Res. Bull. Mo. Agric. Exp. Stn., Columbia, n. 488, p. 4-18, 1951.

BERG, R.T.; BUTTERFIELD, R.M. Nuevos conceptos sobre desarrollo de ganado vacuno. Zaragoza: Acribia, 1979. $297 \mathrm{p}$.

BOER, T. Veal production in the European Community: new trends in veal calf production. In: INTERNATIONAL SYMPOSYUM ON VEAL PRODUCTION CALF PRODUCTION, Wageningen-Netherlands. Proceedings... Wageningen: EAAP Publication, 1991. p. 8-15. 
BOND, T.E.; KELLY, C.F. The black thermometer in agricultural research. Agricultural Engineering, St. Joseph, MI., 1955. 10 p.

BOSE, P.K. Animal progress report. Haringatta: Annimal Nutrition Research Center, 1964. $125 \mathrm{p}$.

BRAY, D.R.; BREEDE, D.K.; BUCKLIN, R.A; HAHN, G.L. Cooling, shade and sprinkling. In: H. H. VAN HORN AND C. J. WILCOX. Large dairy herd management. Champaign, IL.: American Dairy Science Association, 1992. p. 655-663.

BRODY, S. Influence of temperature $50^{\circ} \mathrm{F}$ to $100^{\circ} \mathrm{F}$, on the blood composition of Jersey and Holstein cows. Res. Bull. Mo. Agric. Exp. Stn., n. 433, p. 1-37, 1949.

BROOM, D.M. Animal welfare: its scientific measurent and current relevance to animal husbandry in Europe. In: Phillips, C; Piggins, D. (Eds.). Farms animals and the environment. WallingFord, UK: CAB, 1992. p. 245-253.

BUFFINGTON, D.E.; COLAZZO-AROCHO, A.; CANTON, G.H.; PITT, D. Black globe-humidity index (BGHI) as comfort equation for dairy cows. Transaction of the ASAE, v. 24, p. 711-714, 1981.

BUVANENDRAN, V.; UMOH, J.E.; ABUBAKAR, B.Y. An evolution of body size as related to weigh of West African breeds of cattle in Nigeria. Journal of Agricultural Science, Cambridge, v. 95, n. 1, p. 219-224, 1982.

CAMPANILLI, M. Amianto é banido na cidade de São Paulo. Ciência e Meio Ambiente (Agência Estado). 2003. Disponível em: http://sites.uol.com.br/acpo94/Relatorio amianto.htm. Acesso em 22/04/2003.

CAMPOS NETO, O. Efeito do estresse térmico sobre alguns parâmetros fisiológicos do líquido ruminal, componentes sanguíneos e consumo de ração de bubalinos em crescimento. 1984. Tese Livre-Docência. Botucatu, FMVZ-UNESP.

CARGILL, B.F.; STEWART, R.T. Effect of humidity on total heat and total vapor dissipation of Holsteins cows. Transactions of the ASAE, v. 9, p. 702766, 1966. 
CLARK, J. A. Environmental aspects of housing for animal production. Northingham: England Britsh Library Cataloguing in Publication Data, 1981. $510 \mathrm{p}$.

CODEAGRO. Coordenadoria de desenvolvimento agropecuário. São Paulo. $2002 . \quad$ (Disponível em: http://www.codeagro.sp.gov.br/camaras setoriais/leite derivados/. Acesso em 23/03/2002.

COSTA, E.C. Arquitetura ecológica: condicionamento térmico natural. São Paulo: Edgard Blucher, 1982. 264 p.

COUTTS, R.S.P. Wood fibre reinforced cement composites. In: R. N. SWAMY. Natural fibre reinforced cement and concrete. Glasgow: Blackie, 1988. p. 1-62. (Concrete Technology and Design, 5).

CUNHA, L.; SAVASTANO JR, H.; MIASIRO, H.Y. Fabricação de telhas de argamassa de cimento Portland com adição de escória de alto forno. In: CONGRESSO BRASILEIRO DE ENGENHARIA AGRÍCOLA. Anais... Foz do Iguaçu: Sociedade Brasileira de Engenharia Agrícola, 2001. (CD-ROM).

DAS, S.K.; UPADHYAY, R.C.; MADAN, M.L. Heat stress in Murrah buffalo calves. Livestock Production Science, v. 61, p.p. 71-78, 1999.

DAVIS, A.V.; MERILAN, C.P. Effect of constant environmental temperature and relative humidity on feed digestion for lactation Holsteins cows. Journal of Dairy Science, Champaign, n. 43, p. 871-875, 1960.

DELVASTO, S.A.; GUTIERREZ, R.; LOPEZ, M.M. Como hacer tejas com fibra de fique. 2. ed. Cali: Departamento de Materiales de Ingeniería Universidad del Valle, 1995. 16 p. (Programa "Aprovechamiento Integral del Fique", 4).

DEVITO, R.A. Estudos físicos e mecânicos de telhas de cimento de escória de alto-forno reforçado com fibras celulósicas residuais. 2003. 63p. (Dissertação de Mestrado) - Escola de Engenharia de São Carlos, Universidade de São Paulo, São Carlos, Brasil.

ESMAY, M.L. Principles of animal environmental. West Port, C.T.: Avi Publishing, 1979. 325 p.

ETERNIT. Conforto térmico. São Paulo: Eternit, 1981. 12 p. (Boletim, 110). 
EUCLIDES FILHO, K.; FIGUEREDO, G.R.; EUCLIDES, V.P.B. et al. Conversão alimentar e ganho de peso de animais Nelore e F1's SimentalNelore e Angus-Nelore. In: REUNIÃO ANUAL DA SOCIEDADE BRASILEIRA DE ZOOTECNIA, Fortaleza. Anais... Fortaleza: SBZ, 1996. p. 26.

GILBERT G. Sêmen sexado: o resto da história. Notícias da Genética Avançada (Genética Avançada). 2004. Disponível em: http://www.geneticaavancada.com.br/sêmen sexado.htm. Acesso em 21/01/2004.

GRAM, H.E. Durability of natural fibres in concrete. In: R. N. SWAMY, ed. Natural fibre reinforced cement and concrete. Glasgow: Blackie, 1988. p. 143-172.

GRAM, H.E.; GUT, P. Directives pour le controle de qualite. St Gallen: Skat/BIT, 1994. 69 p. (Serie Pedagogique TFM/TVM: Outil 23).

GUIMARÃES, S.S. Vegetable fiber-cement composites. In: INTERNATIONAL SYMPOSIUM ON VEGETABLE PLANTS AND THEIR FIBRES AS BUILDING MATERIALS, 2., 1990, Salvador. Proceedings... London: Chapman and Hall, 1990. p. 98-107.

HALLET, C.J.; COOK, J.G.H. Chim Acta, v. 35, p. 33, 1971.

HANCOCK, J.; PAYNE, W. The direct effect of tropical climate on the performance of european-type cattle. I Growth. Emp. Journal Exper. Agric., Oxford, v. 89, n. 23, p. 55-74, 1955.

HEAD, H.H. Management of dairy cattle in tropical and subtropical environments. In: CONGRESSO BRASILEIRO DE BIOMETEOROLOGIA, Jaboticabal. Anais... SBBiomet, 1995. p. 26-68.

HEDRICK, H.B.; ABERLE, E.D.; FORREST, J.C. et al. Principles of meat science. Dubuque: Kendall/Hunt Publishing Company, 1994.

HENRY, R.J. Clinical chemistry principles and technics. New York: Harper \& Row, 1968. 
HISSATUGUE, K.; MACHADO, C.E.P. Influência da temperatura e umidade relativa ambiente sobre o crescimento de bezerros da raça holandesa preta $\mathrm{e}$ branca. Zootecnia, Nova Odessa, v. 15, n. 13, p. 141-146, 1977.

JACOBSEN, K.L. The well-being of dairy cows in hot and humid climates. II. reducing stress. Compendium of Continues Education in Pratical Veterinary, v. 18. p. 242-254, 1996.

JOHN, V.M. Pesquisa e desenvolvimento de mercado para resíduos. In: WORKSHOP RECICLAGEM E REUTILIZAÇÃO DE RESÍDUOS COMO MATERIAIS DE CONSTRUÇÃO CIVIL, São Paulo, 1996. Anais.. São Paulo: EP-USP/Antac, 1997. p. 21-30.

KAWABATA, C.Y. Desempenho térmico de diferentes tipos de telhado em bezerreiros individuais. 2003. 94 p. (Dissertação de Mestrado) - Faculdade de Zootecnia e Engenharia de Alimentos, Universidade de São Paulo, Pirassununga, SP, Brasil.

KELLY, T.G.; DODD, V.A., RUANE, D.J., FALLON, R.J.; TUITES, P.J. An assessment of the influence of some housing designs and environmental factors on calf performance. Journal Agricultural Engineering Research, v. 30, p. 175-84, 1984.

LEE, A. O impacto da substituição do telhado de fibrocimento. 2000. Monografia apresentada ao Departamento de Engenharia de Construção Civil da Escola Politécnica Universidade de São Paulo, São Paulo.

LEE, J.E.; SEARS, F.W. Termodinâmica. Rio de Janeiro: McGraw Hill, 1992. p. 302.

LUCCI, C.S. Bovinos leiteiros jovens. São Paulo: Nobel/EDUSP, 1989. 371 p.

MARTELLO, L.S. Diferentes recursos de climatização e sua influência na produção de leite, na termorregulação dos animais e no investimento das instalações. 2002. 67 p. (Dissertação de Mestrado) - Faculdade de Zootecnia e Engenharia de Alimentos, Universidade de São Paulo, Pirassununga, SP, Brasil.

MARTINEK, R.G. American Medicine Technology, v. 32, n. 6, p. 700, 1970. 
MCDOWELL, R.E.; HOOVEN, N.W.; CAMOENS, J.K. Effects of climate on performance of Holsteins in first lactation. Journal Dairy Science, v. 59, p. 965-973, 1976.

MCKEITH , F.K.; WILSON, L.L. Veal productions and quality. In: RECIP. MEAT. CONFERENCE, 1994. Proceedings... p. 47-55.

MCNEILL, M.S.; GRIFFIN, D.B.; DOCKERTY, T.R.; et al. Retail yield and fabrication times for veal as influenced by purchasing options and merchandising styles. Journal of Animal Science, v. 76, p. 1613-1620, 1998.

MCRAE, A.F. Girth measurement and live weight in Friesian bull calves. Dairy Farming Annual, England, v. 38, p. 190-192, 1986.

MENON, G.N.; SHUKLA, P.C.; PATEL, B.M. Study on nonprotein nitrogen in the serum of Gir cattle. Journal of Dairy Science, Champaign, v. 22, p. 119120, 1969.

MISRA, M.S.; SENGUPTA, B.P.; ROY, A. Physiological reactions of buffalo cows maintained in two different housing. Indian Journal Dairy Science, New Delhi, v. 76, p. 203-215, 1963.

MODDY, E.G.; SOEST, P.J. van; MCDOWELL, R.E.; FORD, G.L. Effect of high temperature and dietary fat on performance of lactating cows. Journal of Dairy Science, Champaign, n. 50, p. 1909-1916, 1967.

MULLER, P.B. Bioclimatologia aplicada aos animais domésticos. 3. ed. Porto Alegre: Sulina, 1989. 262 p.

NÄÄS, I.A. Tipologia de instalações em clima quente. In: SIMPÓSIO BRASILEIRO DE AMBIÊNCIA NA PRODUÇÃO DE LEITE, Piracicaba, 1998. Anais... Piracicaba: FEALQ, 1998. p. 146-155.

NÄÄS, I.A.; ARCARO JÚNIOR, I. Influência de ventilação e aspersão em sistemas de sombreamento artificial para vacas em lactação em condições de calor. Revista Brasileira de Engenharia Agrícola e Ambiental, v. 5, n. 1, p. 139-142, 2001.

OLIVEIRA, C.T.A. Água do poro de pastas cimento de escória. 2000. 162 p. (Tese de Doutorado) - Escola Politécnica, Universidade de São Paulo, São Paulo, Brasil. 
PINHEIRO, M.G.; MARTINS M.I.E.G.; BORBA, M.M.Z; et al. Economics aspects of environmental cooling for milk production. In; WORLD CONFERENCE ON ANIMAL PRODUCTION, 9., 2003. Proceedings... Porto Alegre, RS, 2003. (CD-ROM).

PINHEIRO, M.G.; SILVA, I.J.O.; NOGUEIRA, J.R.; LEME, P.R.; ROMA JÚNIOR, L.C.; MACARI, M.; LIMA, M.L.P. Efeito do ambiente climatizado sobre a freqüência respiratória de vacas da raça Jersey. In: REUNIÃO ANUAL DA SOCIEDADE BRASILEIRA DE ZOOTECNIA, 38., Piracicaba Anais... 2001, (CD-ROM).

PINHEIRO, M.G.; ROMA JÚNIOR, L.C.; SANTOS, A.L.; SIMILI, F.F.; NOGUEIRA, J.R.; LIMA M.L.P.; LIMA, N.C. Efeito do ambiente da sala de espera sobre a temperatura da pela de vacas da raça Jersey. In: REUNIÃO ANUAL DA SOCIEDADE BRASILEIRA DE ZOOTECNIA, 37., 2000, Viçosa. Anais... Viçosa, MG: Universidade Federal de Viçosa, 2000. (CD-ROM)

PRESTON, T.R.; WILLIS, M.B. Intensive beef production. 2. ed. Oxford: Pergamon, 1974. $546 \mathrm{p}$.

RIBEIRO FILHO, H.L. Estudo comparativo de métodos de estimativa de peso vivo em novilhos mestiços (Holandês x Zebu) confinados. 1991. (Dissertação de Mestrado) - Lavras, Escola Superior de Agricultura de Lavras.

RIBEIRO, T.R.; PEREIRA, J.C.; LEAO, M.I.et al. Tamanho de órgãos e vísceras de bezerros Holandeses, para a produção de vitelos, recebendo dietas com diferentes níveis de concentrado. Revista Brasileira de Zootecnia, v. 30, n. 6, supl. 1, p. 2163-2168, 2001.

RIBEIRO, T.R. Desempenho e qualidade da carcaça de bezerros Holandeses alimentados com dietas contendo diferentes níveis de concentrado. 1997. 89 p. (Dissertação de Mestrado) - Viçosa, Universidade Federal de Viçosa, MG.

ROMA JÚNIOR, L.C.; SILVA, I.J.O.; PINHEIRO, M.G.; PIEDADE, S.M.S. Avaliação física do sistema de resfriamento adiabático evaporativo (SRAE) em instalações tipo freestall para bovinos de leite. In: CONGRESSO BRASILEIRO DE ENGENHARIA AGRÍCOLA. Anais... Foz do Iguaçu, PR, Brasil, 2001. (CD-ROM). 
ROSA, Y.B.C.J. Influência de três materiais de cobertura no índice de conforto térmico, em condições de verão. 1984. 77 p. (Dissertação de Mestrado)- Viçosa, MG. UFV.

SALLES, M.S.V.; LUCCI, C.S. Monensina para bezerros ruminantes em crescimento acelerado. 1. desempenho. Revista Brasileira de Zootecnia, v. 29, n. 2, p. 573-581 mar/abr. 2000.

SANTOS, L.E.; FONTANELLO, D.; REIS, F.M.; RIBEIRO, M.C.R. Temperatura retal em bezerros mestiços Suíço x Guzerá. Revista Zootecnia, Nova Odessa, v. 13, n. 3, p. 157-162, jul/set. 1975.

SAS/STAT. User's guide, version 6. 4. ed. Cary, North Carolina: SAS Institute Inc. v. 2, 1998.

SAVASTANO JÚNIOR, H.; SILVA, A.F; BARBALHO, R.L.C. Considerações a respeito da estrutura de custos de produção de leite tipo $B$ : analise da região de Descalvado/SP. In: REUNIÃO DA SOCIEDADE BRASILEIRA DE ZOOTECNIA, 32. , Brasília, 1995. Anais... Brasília: SBZ, jul. 1995. p. 605-7.

SAVASTANO JÚNIOR, H.; WARDEN, P.G.; COUTTS, R.S.P. Performance of low-cost vegetable fibre-cement composites under Weathering. In: CIB WORLD BUILDING CONGRESS, Wellington, New Zealand, 2001. 11 p.

SAVASTANO JÚNIOR, $\mathrm{H}$. Materiais à base de cimento reforçados com fibra vegetal: reciclagem de resíduos para a construção de baixo custo. 2000. 144 p. Tese (Livre-Docência) - Escola Politécnica da Universidade de São Paulo, São Paulo.

SAVASTANO JÚNIOR, $\mathrm{H}$. Sustainable cement based materials and techniques for rural construction. In: AGRIBUILDING 2001, Campinas/SP. Proceedings... Concórdia/SC, 2001. p. 8-27. 1 CD-ROM/Invited lecture.

SAVASTANO JUNIOR, $\mathrm{H}$. Processo de obtenção de telha de fibrocimento com reforço à base de polpa celulósica, por meio de sucção de água e prensagem, e produtos assim obtidos. Patente: Privilégio e Inovação. n. 0201204-9, "Invenção de processo e produto obtido". 02 de abr. de 2002 (Depósito no INPI).

SAVASTANO JÚNIOR, H.; PIMENTEL, L. Viabilidade do aproveitamento de resíduos de fibras vegetais para fins de obtenção de material de construção. 
Revista Brasileira de Engenharia Agrícola e Ambiental, Campina Grande, PB., v. 4, n. 1, p. 103-110, 2000.

SAVASTANO, S.A.A.L. Instalações alternativas para bezerros leiteiros durante a fase de aleitamento. 1994. 69 p. (Dissertação de Mestrado) Universidade Estadual Paulista, Faculdade de Ciências Agrárias e Veterinária, Campus Jaboticabal.

SAXENA, M.; MORCHHALE, R.K.; MESHRAM, A.N.; KHAZANCHI, A.C. Development of sisal cement composites as substitute for asbestos cement components for roofing. In: INTERNATIONAL SYMPOSIUM ON FIBRE REINFORCED CEMENT AND CONCRETE, 4., Sheffield, 1992. Proceedings... London: E\&FN Spon, 1992. p. 1140-1151.

SEVEGNANI, K.B.; GHELFI, H.F.; SILVA, I.J.O. Comparação de vários materiais de cobertura através de índices de conforto térmico. Scientia Agricola, Piracicaba, v. 51, n. 1, p. 01-7, 1994.

SILANIKOVE, N. Effects of water scarcity and hot environment on appetite and digestion in ruminants: a review. Livestock Production Science, v. 30, p. 163-170, 1992.

SILANIKOVE, N. Effects of heat stress on the welfare of extensively managed domestic ruminants. Livestock Production Science, v. 67, p. 1-18, 2000.

SILVA, I.J.O. Climatização das instalações para bovinos leiteiros. In: SIMPÓSIO BRASILEIRO DE AMBIÊNCIA NA PRODUÇÃO DE LEITE, Piracicaba, 1998. Anais... Piracicaba: FEALQ, 1998. p. 114-145.

SILVA, I.J.O.; GHELFI FILHO, H.; CONSIGLIERO, F.R. Influência dos materiais de cobertura no conforto térmico de abrigos. Revista Engenharia Rural, Piracicaba, v. 1, n. 2, p. 43-55, 1990.

SILVA, R.G. Introdução à bioclimatologia animal. São Paulo: Nobel, 2000. $286 \mathrm{p}$.

SINGH, S.K.; BHAT, P.N.; GARG, R.C. A note on the estimates of herdability and phenotypic correlations of weight and linear body measurements in halfbreeds of hariana with Holteins-Friesian, Brown Swiss and Jersey cattle. Indian Journal of Animal Science, New Delhi, v. 48, n. 12, p. 906-907, 1978. 
SMITH, J.L.; WILSON, L.L.; SWANSON, D.L. Implant sequence effects in intact male Holstein Veal Calves: live and slaughter traits. Journal of Animal Science, v. 77, p. 3125-3132, 1999.

SOUZA, C.F.; BAÊTA, F.C.; CARDOSO, R.M.; TORRES, R.A. Eficiência de diferentes tipos de bezerreiros, quanto ao conforto térmico, na primavera e no verão em Viçosa, MG. Engenharia na Agricultura, (Série Construções Rurais e Ambiência), v. 1, n. 1, p. 1-12, 1992.

SWENSON, M.J. Propriedades fisiológicas e constituintes químicos e celulares do sangue. In: Dukes' physiology of domestic animals. Cornell University, 1993. p. 19-43.

TAYLOR, H.F.W. Cement Chemistry. 2. ed. London: Thomas Telford, 1997.

THOM, E.C. The discomfort index. Weatherwise, 1959. v. 12, p. 57-59.

TITTO, E.A.L. Clima: influencia na produção de leite. In: SIMPÓSIO BRASILEIRO DE AMBIÊNCIA NA PRODUÇÃO DE LEITE, Piracicaba, 1998. Anais... Piracicaba: FEALQ, 1998. p. 10-23.

TOLÊDO FILHO, R.D.; SCRIVENER K.; ENGLAND, G.L; GHAVAMI, K. Durability of alkali-sensitive sisal and coconut fibres in cement mortar composites. Cement \& Concrete Composites, v. 22, n. 2, p. 127-143, 2000.

TOLEDO, R. Vitelo tropical: bom para o produtor e consumidor. Notícia à imprensa IAPAR. n.10. 2001a. (informação obtida no site http://www.pr.gov.br/noticia no dia 13/04/2002)

TOLEDO, R. Programa busca agregar valor aos bezerros machos de rebanho leiteiro. Revista Safra. Maio, 2001b.

USDA. National Agricultural Statistics Service. Washington DC, 1995.

USDA. Cattle and sheep outlook. Econ. Res. Service. USDA. Washington, DC.,1996.

VALLE, C.E. Qualidade ambiental: o desafio de ser competitivo protegendo o meio ambiente. São Paulo, 117p. 1995. 
VEIGA, J.S. et al. Aspectos fisiológicos, associados com a adaptação de bovinos nos climas tropicais e subtropicais: espessura do pelame de revestimento do corpo. Arquivo da Escola de Veterinária, Belo Horizonte/MG, n. 16, p. 113-137, 1964.

WELDI, J.R.; MCDOWELL, R.E.; VAN SOEST, P.J.; BOND, J. Influence of heat stress on rumen acid levels and some blood constituent in cattle. Journal of Animal Science, Champaign, v. 23, p. 142-53, 1964.

WHEELER, T.L.; KOOHMARAIE, M.; SHACKELFORD; S.D. Standardized Warner-Bratzler shear force procedures for meat tenderness measurement. 1995.1 Disponível no site: http://192.133.74.26/MRU WWW/protocol/WBS.html

WIERENGA, H.K. Behavioural problems in fattening bulls. In: SCHLICHTING, M.C., SMIDTS, D. (Eds.). Welfare aspects of housing systems for veal calves and fattering Bulls. Luxembourg: CEC, 1987. p.105-122.

WILCOX, C.J. Growth, type, and dairy beef. In: VAN HORN, H. H.; WILCOX, C. J. eds. Large dairy herd management. Champaign, IL.: American Dairy Science Association, 1992. p. 36-41.

WILSON, L.L.; EGAN, C.L.; HENNING, W.R.; MILLS, E.W. Effects of Live animal performance and hemoglobin level on special-fed veal carcass characteristics. Meat Science, v. 41, n. 1, p. 89-96, 1995.

YOUNG, B.A. Implications of excessive heat load to the welfare of cattle in feedlots. In: Recent advances in animal nutrition in australia. Univ. New England, Armidale, NSW, Australia, 1993. p. 45-50.

YOUSEF, M.K. Stress physiology in livestock: basic principles. Boca Raton, FL, USA: CRC, 1985. v. 1.

YOUSEF, M.K.; JOHNSON, H.D. Some blood constituents of dairy cattle. Influence of thyroxine and high environmental temperature. Journal of Dairy Science, New Delhi, n. 48, p. 1074-1078, 1965. 